Cochrane Database of Systematic Reviews

\title{
Orthodontic treatment for prominent upper front teeth (Class II malocclusion) in children and adolescents (Review)
}

Batista KBSL, Thiruvenkatachari B, Harrison JE, O'Brien KD

Batista KBSL, Thiruvenkatachari B, Harrison JE, O'Brien KD.

Orthodontic treatment for prominent upper front teeth (Class II malocclusion) in children and adolescents.

Cochrane Database of Systematic Reviews 2018, Issue 3. Art. No.: CD003452.

DOI: 10.1002/14651858.CD003452.pub4.

www.cochranelibrary.com 
TABLE OF CONTENTS

ABSTRACT

PLAIN LANGUAGE SUMMARY

SUMMARY OF FINDINGS

BACKGROUND

OBJECTIVES

METHODS

RESULTS

Figure 1.

Figure 2.

DISCUSSION

AUTHORS' CONCLUSIONS

\section{ACKNOWLEDGEMENTS}

REFERENCES

\section{CHARACTERISTICS OF STUDIES}

DATA AND ANALYSES

Analysis 1.1. Comparison 1 Early orthodontic treatment: two-phase versus one-phase treatment, Outcome 1 Outcomes at the end of phase I: functional versus observation.

Analysis 1.2. Comparison 1 Early orthodontic treatment: two-phase versus one-phase treatment, Outcome 2 Incidence of new incisal trauma during phase I treatment: functional versus observation.

Analysis 1.3. Comparison 1 Early orthodontic treatment: two-phase versus one-phase treatment, Outcome 3 Outcomes at the end of phase I: headgear versus observation.

Analysis 1.4. Comparison 1 Early orthodontic treatment: two-phase versus one-phase treatment, Outcome 4 Incidence of new incisal trauma during phase I treatment: headgear versus observation.

Analysis 1.5. Comparison 1 Early orthodontic treatment: two-phase versus one-phase treatment, Outcome 5 Outcomes at the end of phase II: functional (2-phase) versus adolescent (1-phase) treatment.

Analysis 1.6. Comparison 1 Early orthodontic treatment: two-phase versus one-phase treatment, Outcome 6 Incidence of new incisal trauma by the end of phase II treatment: functional (2-phase) versus adolescent (1-phase) treatment.

Analysis 1.7. Comparison 1 Early orthodontic treatment: two-phase versus one-phase treatment, Outcome 7 Outcomes at the end of phase II: headgear (2-phase) versus adolescent (1-phase) treatment.

Analysis 1.8. Comparison 1 Early orthodontic treatment: two-phase versus one-phase treatment, Outcome 8 Incidence of new incisal trauma by the end of phase II treatment: headgear (2-phase) versus adolescent (1-phase) treatment.

Analysis 2.1. Comparison 2 Early orthodontic treatment: two-phase appliance 1 (headgear) versus appliance 2 (functional), Outcome 1 Outcomes at the end of phase l: headgear versus functional.

Analysis 2.2. Comparison 2 Early orthodontic treatment: two-phase appliance 1 (headgear) versus appliance 2 (functional), Outcome 2 Incidence of new incisal trauma during phase I treatment: headgear versus functional.

Analysis 2.3. Comparison 2 Early orthodontic treatment: two-phase appliance 1 (headgear) versus appliance 2 (functional), Outcome 3 Outcomes at the end of phase II: headgear versus functional.

Analysis 2.4. Comparison 2 Early orthodontic treatment: two-phase appliance 1 (headgear) versus appliance 2 (functional), Outcome 4 Incidence of new incisal trauma by the end of phase II treatment: headgear versus functional appliance. ..............

Analysis 3.1. Comparison 3 Late orthodontic treatment: functional versus no treatment, Outcome 1 Final overjet. ................. Analysis 3.2. Comparison 3 Late orthodontic treatment: functional versus no treatment, Outcome 2 Final ANB.

Analysis 4.1. Comparison 4 Late orthodontic treatment: different types of appliances used for late treatment, Outcome 1 Twin Block versus other functional appliances (R-appliance, Bionator, Bite-Jumping appliance, Dynamax and Herbst).

Analysis 4.2. Comparison 4 Late orthodontic treatment: different types of appliances used for late treatment, Outcome 2 Twin Block conventional versus other Twin Block modifications.

Analysis 4.3. Comparison 4 Late orthodontic treatment: different types of appliances used for late treatment, Outcome 3 Functional (Activator) versus prefabricated functional myobrace appliance (PFA).

Analysis 4.4. Comparison 4 Late orthodontic treatment: different types of appliances used for late treatment, Outcome 4 Functional (Activator) versus fixed functional (FORSUS FRD EZ).

Analysis 4.5. Comparison 4 Late orthodontic treatment: different types of appliances used for late treatment, Outcome 5 Fixed functional (FORSUS FRD) versus fixed functional with mini-implants (FMI).

Analysis 4.6. Comparison 4 Late orthodontic treatment: different types of appliances used for late treatment, Outcome 6 Fixed functional (FORSUS FRD) versus fixed functional with mini-implants (FMI) - patient satisfaction with results. 
Analysis 4.7. Comparison 4 Late orthodontic treatment: different types of appliances used for late treatment, Outcome 7 Rappliance versus AIBP.

Analysis 4.8. Comparison 4 Late orthodontic treatment: different types of appliances used for late treatment, Outcome 8 Removable functional appliance versus fixed functional appliance.

Analysis 4.9. Comparison 4 Late orthodontic treatment: different types of appliances used for late treatment, Outcome 9 FORSUS versus intermaxillary elastics.

Analysis 4.10. Comparison 4 Late orthodontic treatment: different types of appliances used for late treatment, Outcome 10 FMA stepwise (SWG) versus FMA single step (SSG).

Analysis 4.11. Comparison 4 Late orthodontic treatment: different types of appliances used for late treatment, Outcome 11 Harvold Activator versus Frankel function regulator.

APPENDICES

WHAT'S NEW

HISTORY

CONTRIBUTIONS OF AUTHORS

DECLARATIONS OF INTEREST

SOURCES OF SUPPORT

DIFFERENCES BETWEEN PROTOCOL AND REVIEW

INDEX TERMS

INDEX TERMS 
[Intervention Review]

\title{
Orthodontic treatment for prominent upper front teeth (Class II malocclusion) in children and adolescents
}

\author{
Klaus BSL Batista1, Badri Thiruvenkatachari², Jayne E Harrison³, Kevin D O'Brien4
}

1Department of Preventive and Public Dentistry, Rio de Janeiro State University, Rio de Janeiro, Brazil. 2School of Dentistry, The University of Manchester, Manchester, UK. ${ }^{3}$ Orthodontic Department, Liverpool University Dental Hospital, Liverpool, UK. ${ }^{4}$ Division of Dentistry, School of Medical Sciences, Faculty of Biology, Medicine and Health, The University of Manchester, Manchester, UK

Contact: Klaus BSL Batista, Department of Preventive and Public Dentistry, Rio de Janeiro State University, Boulevard 28 de Setembro, 157, Vila Isabel, Rio de Janeiro, CEP: 20551-030, Brazil. klausbarretto@uol.com.br.

Editorial group: Cochrane Oral Health Group.

Publication status and date: New search for studies and content updated (conclusions changed), published in Issue 3, 2018.

Citation: Batista KBSL, Thiruvenkatachari B, Harrison JE, O'Brien KD. Orthodontic treatment for prominent upper front teeth (Class II malocclusion) in children and adolescents. Cochrane Database of Systematic Reviews 2018, Issue 3. Art. No.: CD003452. DOI: 10.1002/14651858.CD003452.pub4.

Copyright ( 2018 The Cochrane Collaboration. Published by John Wiley \& Sons, Ltd.

\section{A B S T R A C T}

\section{Background}

Prominent upper front teeth are a common problem affecting about a quarter of 12 -year-old children in the UK. The condition develops when permanent teeth erupt. These teeth are more likely to be injured and their appearance can cause significant distress. Children are often referred to an orthodontist for treatment with dental braces to reduce the prominence of their teeth. If a child is referred at a young age, the orthodontist is faced with the dilemma of whether to treat the patient early or to wait and provide treatment in adolescence.

\section{Objectives}

To assess the effects of orthodontic treatment for prominent upper front teeth initiated when children are seven to 11 years old ('early treatment' in two phases) compared to in adolescence at around 12 to 16 years old ('late treatment' in one phase); to assess the effects of late treatment compared to no treatment; and to assess the effects of different types of orthodontic braces.

\section{Search methods}

Cochrane Oral Health's Information Specialist searched the following databases: Cochrane Oral Health's Trials Register (to 27 September 2017), the Cochrane Central Register of Controlled Trials (CENTRAL) (the Cochrane Library, 2017, Issue 8), MEDLINE Ovid (1946 to 27 September 2017), and Embase Ovid (1980 to 27 September 2017). The US National Institutes of Health Ongoing Trials Registry (ClinicalTrials.gov) and the World Health Organization International Clinical Trials Registry Platform were searched for ongoing trials. No restrictions were placed on the language or date of publication when searching the electronic databases.

\section{Selection criteria}

Randomised controlled trials of orthodontic treatments to correct prominent upper front teeth (Class II malocclusion) in children and adolescents. We included trials that compared early treatment in children (two-phase) with any type of orthodontic braces (removable, fixed, functional) or head-braces versus late treatment in adolescents (one-phase) with any type of orthodontic braces or head-braces, and trials that compared any type of orthodontic braces or head-braces versus no treatment or another type of orthodontic brace or appliance (where treatment started at a similar age in the intervention groups).

We excluded trials involving participants with a cleft lip or palate, or other craniofacial deformity/syndrome, and trials that recruited patients who had previously received surgical treatment for their Class II malocclusion. 


\section{Data collection and analysis}

Review authors screened the search results, extracted data and assessed risk of bias independently. We used odds ratios (ORs) and $95 \%$ confidence intervals (Cls) for dichotomous outcomes, and mean differences (MDs) and 95\% Cls for continuous outcomes. We used the fixed-effect model for meta-analyses including two or three studies and the random-effects model for more than three studies.

\section{Main results}

We included 27 RCTs based on data from 1251 participants.

Three trials compared early treatment with a functional appliance versus late treatment for overjet, ANB and incisal trauma. After phase one of early treatment (i.e. before the other group had received any intervention), there was a reduction in overjet and ANB reduction favouring treatment with a functional appliance; however, when both groups had completed treatment, there was no difference between groups in final overjet (MD $0.21,95 \% \mathrm{Cl}-0.10$ to $0.51, \mathrm{P}=0.18 ; 343$ participants) (low-quality evidence) or $\mathrm{ANB}$ ( $\mathrm{MD}-0.02,95 \% \mathrm{Cl}-0.47$ to 0.43; 347 participants) (moderate-quality evidence). Early treatment with functional appliances reduced the incidence of incisal trauma compared to late treatment (OR $0.56,95 \% \mathrm{Cl} 0.33$ to $0.95 ; 332$ participants) (moderate-quality evidence). The difference in the incidence of incisal trauma was clinically important with $30 \%$ (51/171) of participants reporting new trauma in the late treatment group compared to only $19 \%$ (31/161) of participants who had received early treatment.

Two trials compared early treatment using headgear versus late treatment. After phase one of early treatment, headgear had reduced overjet and ANB; however, when both groups had completed treatment, there was no evidence of a difference between groups in overjet (MD $-0.22,95 \% \mathrm{Cl}-0.56$ to $0.12 ; 238$ participants) (low-quality evidence) or ANB (MD $-0.27,95 \% \mathrm{Cl}-0.80$ to $0.26 ; 231$ participants) (lowquality evidence). Early (two-phase) treatment with headgear reduced the incidence of incisal trauma (OR $0.45,95 \% \mathrm{Cl} 0.25$ to $0.80 ; 237$ participants) (low-quality evidence), with almost half the incidence of new incisal trauma (24/117) compared to the late treatment group (44/120).

Seven trials compared late treatment with functional appliances versus no treatment. There was a reduction in final overjet with both fixed functional appliances (MD $-5.46 \mathrm{~mm}, 95 \% \mathrm{Cl}-6.63$ to $-4.28 ; 2$ trials, 61 participants) and removable functional appliances (MD -4.62 , $95 \% \mathrm{Cl}-5.33$ to $-3.92 ; 3$ trials, 122 participants) (low-quality evidence). There was no evidence of a difference in final ANB between fixed functional appliances and no treatment (MD $-0.53^{\circ}, 95 \% \mathrm{Cl}-1.27$ to $-0.22 ; 3$ trials, 89 participants) (low-quality evidence), but removable functional appliances seemed to reduce ANB compared to no treatment (MD $-2.37^{\circ}, 95 \% \mathrm{Cl}-3.01$ to $-1.74 ; 2$ trials, 99 participants) (lowquality evidence).

Six trials compared orthodontic treatment for adolescents with Twin Block versus other appliances and found no difference in overjet (0.08 $\mathrm{mm}, 95 \% \mathrm{Cl}-0.60$ to 0.76 ; 4 trials, 259 participants) (low-quality evidence). The reduction in ANB favoured treatment with a Twin Block $\left(-0.56^{\circ}, 95 \% \mathrm{Cl}-0.96\right.$ to $-0.16 ; 6$ trials, 320 participants) (low-quality evidence).

Three trials compared orthodontic treatment for adolescents with removable functional appliances versus fixed functional appliances and found a reduction in overjet in favour of fixed appliances $(0.74,95 \% \mathrm{Cl} 0.15$ to 1.33 ; two trials, 154 participants) (low-quality evidence), and a reduction in ANB in favour of removable appliances $\left(-1.04^{\circ}, 95 \% \mathrm{Cl}-1.60\right.$ to $-0.49 ; 3$ trials, 185 participants) (low-quality evidence).

\section{Authors' conclusions}

Evidence of low to moderate quality suggests that providing early orthodontic treatment for children with prominent upper front teeth is more effective for reducing the incidence of incisal trauma than providing one course of orthodontic treatment in adolescence. There appear to be no other advantages of providing early treatment when compared to late treatment. Low-quality evidence suggests that, compared to no treatment, late treatment in adolescence with functional appliances, is effective for reducing the prominence of upper front teeth.

\section{PLAIN LANGUAGE SUMMARY}

\section{Orthodontic treatment for prominent upper front teeth in children}

\section{Review question}

This review, carried out by authors working with Cochrane Oral Health, has been produced to assess the effects of orthodontic treatment (treatment by dentists who specialise in the growth, function and position of teeth and jaws) for prominent upper front teeth in children. The review looks at whether this treatment is best initiated at seven to 11 years old (early treatment in two phases), or in adolescence, at around age 12 to 16 years (late treatment in one phase). The use of different types of braces was also assessed.

\section{Background}

Prominent (or sticking out) upper front teeth are a common problem in children around the world. For example, this condition affects about a quarter of 12-year-old children in the UK. The correction of this condition is one of the most common treatments performed by orthodontists (dentists who specialise in the growth, function and position of teeth and jaws). This condition develops when the child's 
permanent teeth erupt. Children are often referred to an orthodontist, for treatment with dental braces, to reduce the prominence of the teeth. Prominent upper front teeth are more likely to be injured and their appearance can cause significant distress.

If a child is referred at a young age, the orthodontist is faced with the dilemma of whether to treat the patient early or to wait until the child is older and provide treatment in adolescence.

In 'early treatment', treatment is given in two phases: first at an early age (seven to 11 years old) and again in adolescence (around 12 to 16 years old). In 'late treatment' (one phase), there is only one course of treatment in adolescence.

As well as the timing of treatment, this review also looked at the different types of braces used: removable, fixed, functional, or head-braces.

\section{Study characteristics}

This review is based on 27 studies including 1251 participants. Participants were children and adolescents aged under 16 years who had prominent upper front teeth (Class II Division 1 malocclusion). The evidence in this review is up to date as of 27 September 2017.

\section{Key results}

The evidence suggests that providing orthodontic early treatment to children with prominent upper front teeth reduces the incidence of damage to upper incisor teeth significantly (middle four teeth at the top) as compared to treatment that is provided in one phase in adolescence. There are no other advantages of providing a two-phase treatment (i.e. between age seven to 11 years and again in adolescence) compared to treatment in one phase in adolescence.

The evidence also suggests that providing treatment with functional appliances for adolescents with prominent upper front teeth, significantly reduces their prominence when compared to adolescents who did not receive any treatment. The studies did not suggest that any particular appliance was better than any other for reducing teeth prominence.

\section{Quality of the evidence}

The overall quality of the evidence is low for most comparisons and outcomes, therefore further research is needed and may change the findings. 


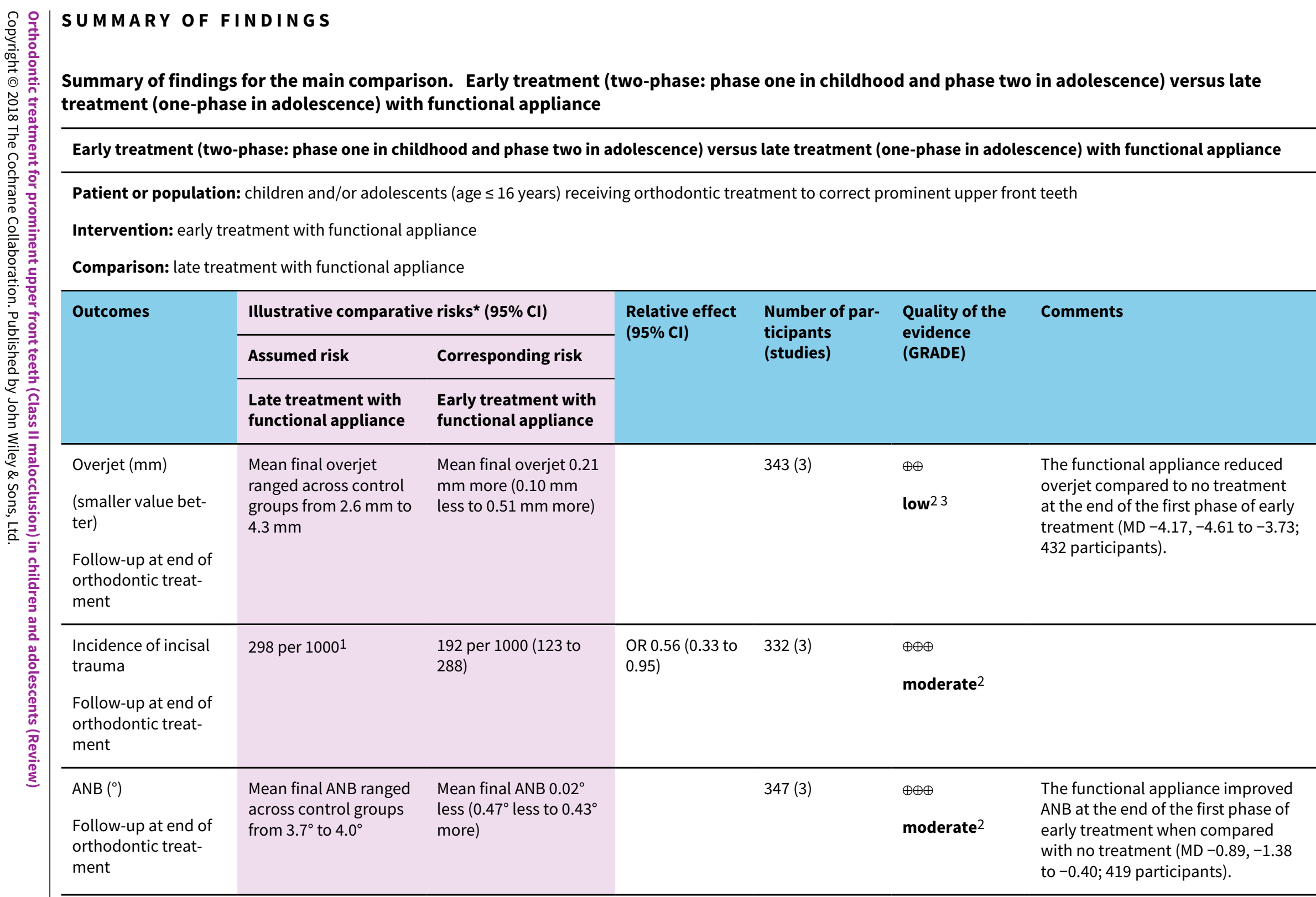

*The basis for the assumed risk (e.g. the median control group risk across studies) is provided in footnotes. The corresponding risk (and its $95 \% \mathrm{Cl}$ ) is based on the assumed risk in the comparison group and the relative effect of the intervention (and its $95 \% \mathrm{Cl}$ ) 
GRADE Working Group grades of evidence

High quality: Further research is very unlikely to change our confidence in the estimate of effect.

Moderate quality: Further research is likely to have an important impact on our confidence in the estimate of effect and may change the estimate.

Low quality: Further research is very likely to have an important impact on our confidence in the estimate of effect and is likely to change the estimate.

Very low quality: We are very uncertain about the estimate.

1 Based on average in control groups

2 Downgraded as 2 of the 3 studies were at high risk of bias

3 Downgraded due to heterogeneity $\left(\mathrm{Chi}^{2}=5.23\right.$, degrees of freedom $(\mathrm{df})=2(\mathrm{P}$ value $\left.=0.07) ; \mathrm{I}^{2}=62 \%\right)$

\section{Summary of findings $\mathbf{2}$. Early treatment (two-phase: phase 1 in childhood and phase $\mathbf{2}$ in adolescence) with headgear appliance versus late} treatment (one-phase in adolescence) with headgear

Early treatment (two-phase: phase 1 in childhood and phase $\mathbf{2}$ in adolescence) with headgear appliance versus late treatment (one-phase in adolescence) with headgear

Patient or population: children and/or adolescents (age $\leq 16$ years) receiving orthodontic treatment to correct prominent upper front teeth

Intervention: early treatment with headgear

Comparison: late treatment with headgear

\begin{tabular}{|c|c|c|c|c|c|c|}
\hline \multirow[t]{3}{*}{ Outcomes } & \multicolumn{2}{|c|}{ Illustrative comparative risks ${ }^{\star}(95 \% \mathrm{Cl})$} & \multirow{3}{*}{$\begin{array}{l}\text { Relative effect } \\
(95 \% \mathrm{CI})\end{array}$} & \multirow{3}{*}{$\begin{array}{l}\text { No of partici- } \\
\text { pants } \\
\text { (studies) }\end{array}$} & \multirow{3}{*}{$\begin{array}{l}\text { Quality of the } \\
\text { evidence } \\
\text { (GRADE) }\end{array}$} & \multirow[t]{3}{*}{ Comments } \\
\hline & Assumed risk & Corresponding risk & & & & \\
\hline & $\begin{array}{l}\text { Late treatment with } \\
\text { headgear }\end{array}$ & $\begin{array}{l}\text { Early treatment with } \\
\text { headgear }\end{array}$ & & & & \\
\hline $\begin{array}{l}\text { Overjet (mm) } \\
\text { (smaller value better) } \\
\text { Follow-up at end of or- } \\
\text { thodontic treatment }\end{array}$ & $\begin{array}{l}\text { Mean final overjet } \\
\text { ranged across control } \\
\text { groups from } 2.4 \mathrm{~mm} \text { to } \\
3.48 \mathrm{~mm}\end{array}$ & $\begin{array}{l}\text { Mean final overjet in the } \\
\text { 2-phase treatment group } \\
\text { was } 0.22 \mathrm{~mm} \text { less ( } 0.56 \\
\mathrm{~mm} \text { less to } 0.12 \mathrm{~mm} \text { more) }\end{array}$ & & $238(2)$ & $\begin{array}{l}\oplus \oplus \\
\text { low }^{2}\end{array}$ & $\begin{array}{l}\text { Headgear reduced overjet com- } \\
\text { pared to no treatment at the } \\
\text { end of the first phase of early } \\
\text { treatment (MD }-1.07,-1.63 \text { to } \\
-0.51 ; 278 \text { participants). }\end{array}$ \\
\hline $\begin{array}{l}\text { Incidence of incisal } \\
\text { trauma } \\
\text { Follow-up at end of or- } \\
\text { thodontic treatment }\end{array}$ & 367 per $1000^{1}$ & 207 per 1000 (126 to 317 ) & $\begin{array}{l}\text { OR } 0.45(0.25 \text { to } \\
0.80)\end{array}$ & $237(2)$ & $\begin{array}{l}\oplus \oplus \\
\text { low }^{2}\end{array}$ & \\
\hline
\end{tabular}


*The basis for the assumed risk (e.g. the median control group risk across studies) is provided in footnotes. The corresponding risk (and its $95 \% \mathrm{Cl}$ ) is based on the assumed risk in the comparison group and the relative effect of the intervention (and its $95 \% \mathrm{Cl}$ )

Cl: confidence interval; MD: mean difference; OR: odds ratio

GRADE Working Group grades of evidence

High quality: Further research is very unlikely to change our confidence in the estimate of effect.

Moderate quality: Further research is likely to have an important impact on our confidence in the estimate of effect and may change the estimate.

Low quality: Further research is very likely to have an important impact on our confidence in the estimate of effect and is likely to change the estimate.

Very low quality: We are very uncertain about the estimate.

1 Based on average in control groups

2 Downgraded twice as both studies at high risk of bias

Summary of findings 3. Late treatment (one-phase in adolescence) with functional appliance versus no treatment for prominent upper front teeth (Class II malocclusion)

Late treatment (one-phase in adolescence) with functional appliance versus no treatment for prominent upper front teeth (Class II malocclusion)

Patient or population: adolescents (age between 12 and 16 years) receiving orthodontic treatment to correct prominent upper front teeth

Intervention: late treatment in adolescence with different types of functional appliances

Comparison: no treatment

\begin{tabular}{|c|c|c|c|c|c|c|}
\hline \multirow[t]{2}{*}{ Outcomes } & \multicolumn{2}{|c|}{ Illustrative comparative risks ${ }^{*}(95 \% \mathrm{CI})$} & \multirow{2}{*}{$\begin{array}{l}\text { Relative effect } \\
(95 \% \mathrm{CI})\end{array}$} & \multirow{2}{*}{$\begin{array}{l}\text { Number of par- } \\
\text { ticipants } \\
\text { (studies) }\end{array}$} & \multirow{2}{*}{$\begin{array}{l}\text { Quality of the } \\
\text { evidence } \\
\text { (GRADE) }\end{array}$} & \multirow[t]{2}{*}{ Comments } \\
\hline & Assumed risk & Corresponding risk & & & & \\
\hline \multicolumn{7}{|c|}{ Fixed functional appliances } \\
\hline
\end{tabular}




\begin{tabular}{|c|c|c|c|c|c|c|c|}
\hline \multicolumn{2}{|c|}{ 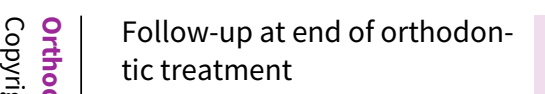 } & & & & & & \\
\hline 苛产. & Incidence of incisal trauma & \multicolumn{6}{|l|}{ Not measured } \\
\hline 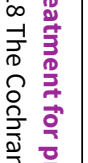 & $\begin{array}{l}\text { ANB }\left(^{\circ}\right) \\
\text { Follow-up at end of orthodon- } \\
\text { tic treatment }\end{array}$ & $\begin{array}{l}\text { Mean final ANB ranged } \\
\text { from } 6.30^{\circ} \text { to } 7.92^{\circ}\end{array}$ & $\begin{array}{l}\text { Mean final ANB was } 0.53^{\circ} \text { lower } \\
\text { (1.27 lower to } 0.22 \text { lower })\end{array}$ & & $\begin{array}{l}89 \\
(3)\end{array}$ & $\begin{array}{l}\oplus \oplus \ominus \ominus \\
\text { low } 2\end{array}$ & \\
\hline$\stackrel{\varrho}{\stackrel{3}{ٍ}}$ & \multicolumn{7}{|c|}{ Removable functional appliances } \\
\hline 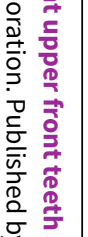 & $\begin{array}{l}\text { Overjet (mm) } \\
\text { (smaller value better) } \\
\text { Follow-up at end of orthodon- } \\
\text { tic treatment }\end{array}$ & $\begin{array}{l}\text { Mean final overjet } \\
\text { ranged from } 7.8 \text { to } 9.9 \\
\mathrm{~mm}\end{array}$ & $\begin{array}{l}\text { Mean final overjet was } 4.62 \mathrm{~mm} \\
\text { lower ( } 5.33 \text { lower to } 3.92 \text { lower) }\end{array}$ & & $\begin{array}{l}122 \\
(3)\end{array}$ & $\begin{array}{l}\oplus \oplus \ominus \ominus \\
\text { low }^{3}\end{array}$ & \\
\hline 울 & Incidence of incisal trauma & Not measured & & & & & \\
\hline 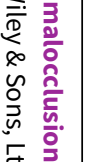 & $\begin{array}{l}\text { ANB }\left(^{\circ}\right) \\
\text { Follow-up at end of orthodon- } \\
\text { tic treatment }\end{array}$ & $\begin{array}{l}\text { Mean final ANB ranged } \\
\text { from } 6.5^{\circ} \text { to } 6.53^{\circ}\end{array}$ & $\begin{array}{l}\text { Mean final ANB was } 2.37^{\circ} \text { lower } \\
\text { (3.01 lower to } 1.74 \text { lower) }\end{array}$ & & $\begin{array}{l}99 \\
(2)\end{array}$ & $\begin{array}{l}\oplus \oplus \odot \odot \\
\operatorname{low}^{3}\end{array}$ & \\
\hline 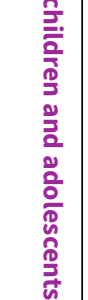 & $\begin{array}{l}1 \text { Downgraded one level as both st } \\
2 \text { Downgraded one level as the thr } \\
3 \text { Downgraded two levels as both } \\
\text { Summary of findings } 4 \text {. Late } \\
\text { prominent upper front teeth }\end{array}$ & $\begin{array}{l}\text { tudies were at unclear ris } \\
\text { ee studies were at uncle } \\
\text { studies were at high risk }\end{array}$ & in adolescence): comparison & $\begin{array}{l}\text { igh heterogeneity } \\
\text { heterogeneity }\left(I^{2}\right.\end{array}$ & pes of applian & used for trea & ent of \\
\hline 变. & \multicolumn{7}{|c|}{$\begin{array}{l}\text { Late treatment (one-phase in adolescence): comparison among different types of appliances used for treatment of prominent upper front teeth (Class II malocclu- } \\
\text { sion) }\end{array}$} \\
\hline & \multicolumn{7}{|c|}{$\begin{array}{l}\text { Patient or population: adolescents (age between } 12 \text { and } 16 \text { years) receiving orthodontic treatment to correct prominent upper front teeth } \\
\text { Intervention: late treatment in adolescence with different types of appliances } \\
\text { Comparison: Twin Block }\end{array}$} \\
\hline & \multirow[t]{2}{*}{ Outcomes } & \multicolumn{2}{|c|}{ Illustrative comparative risks* $(95 \% \mathrm{CI})$} & \multirow{2}{*}{$\begin{array}{l}\text { Relative effect } \\
(95 \% \mathrm{CI})\end{array}$} & \multirow{2}{*}{$\begin{array}{l}\text { № of partici- } \\
\text { pants } \\
\text { (studies) }\end{array}$} & \multirow{2}{*}{\multicolumn{2}{|c|}{$\begin{array}{l}\text { Quality of the } \\
\text { evidence } \\
\text { (GRADE) }\end{array}$}} \\
\hline & & Assumed risk & Corresponding risk & & & & \\
\hline
\end{tabular}




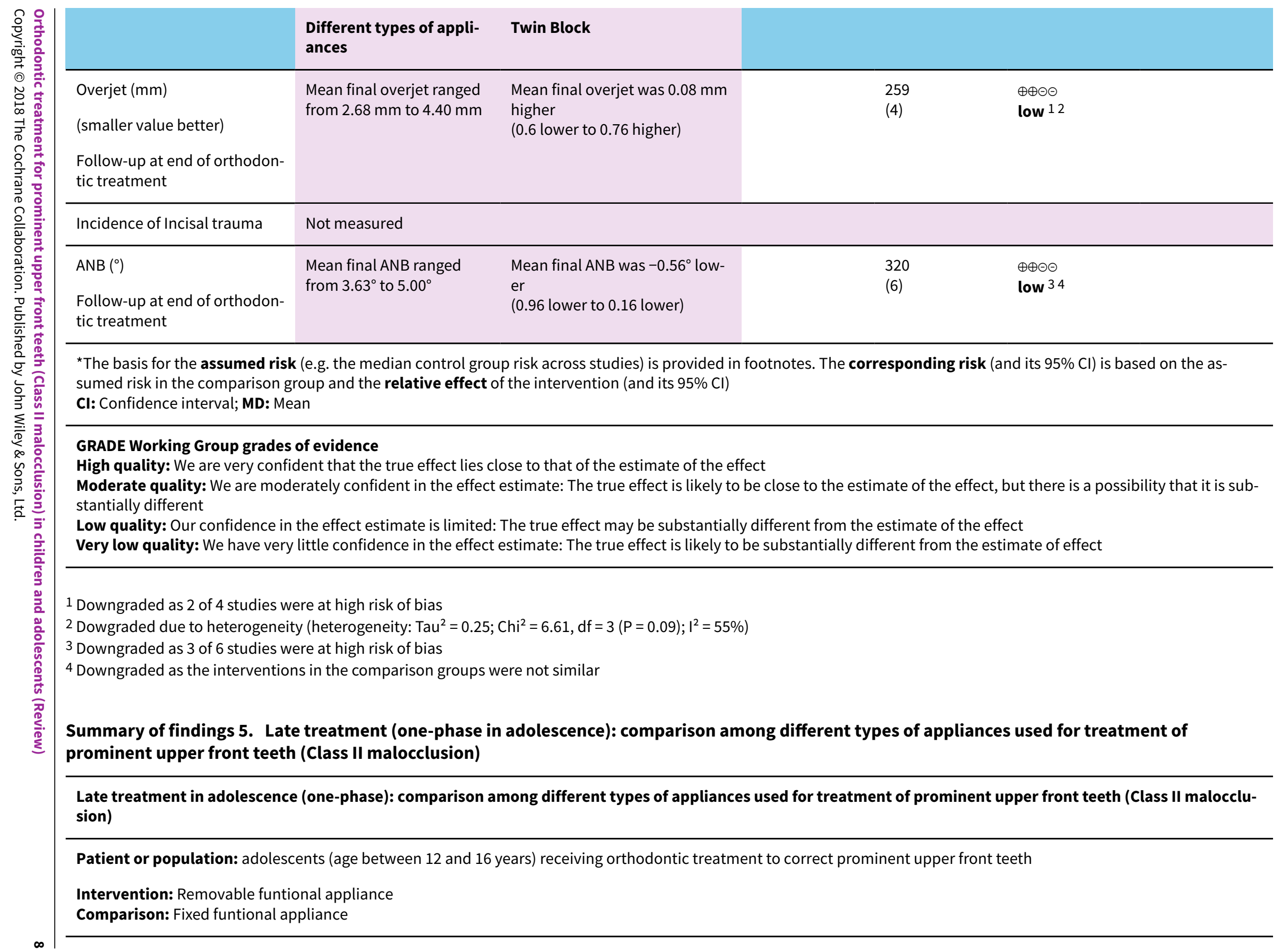




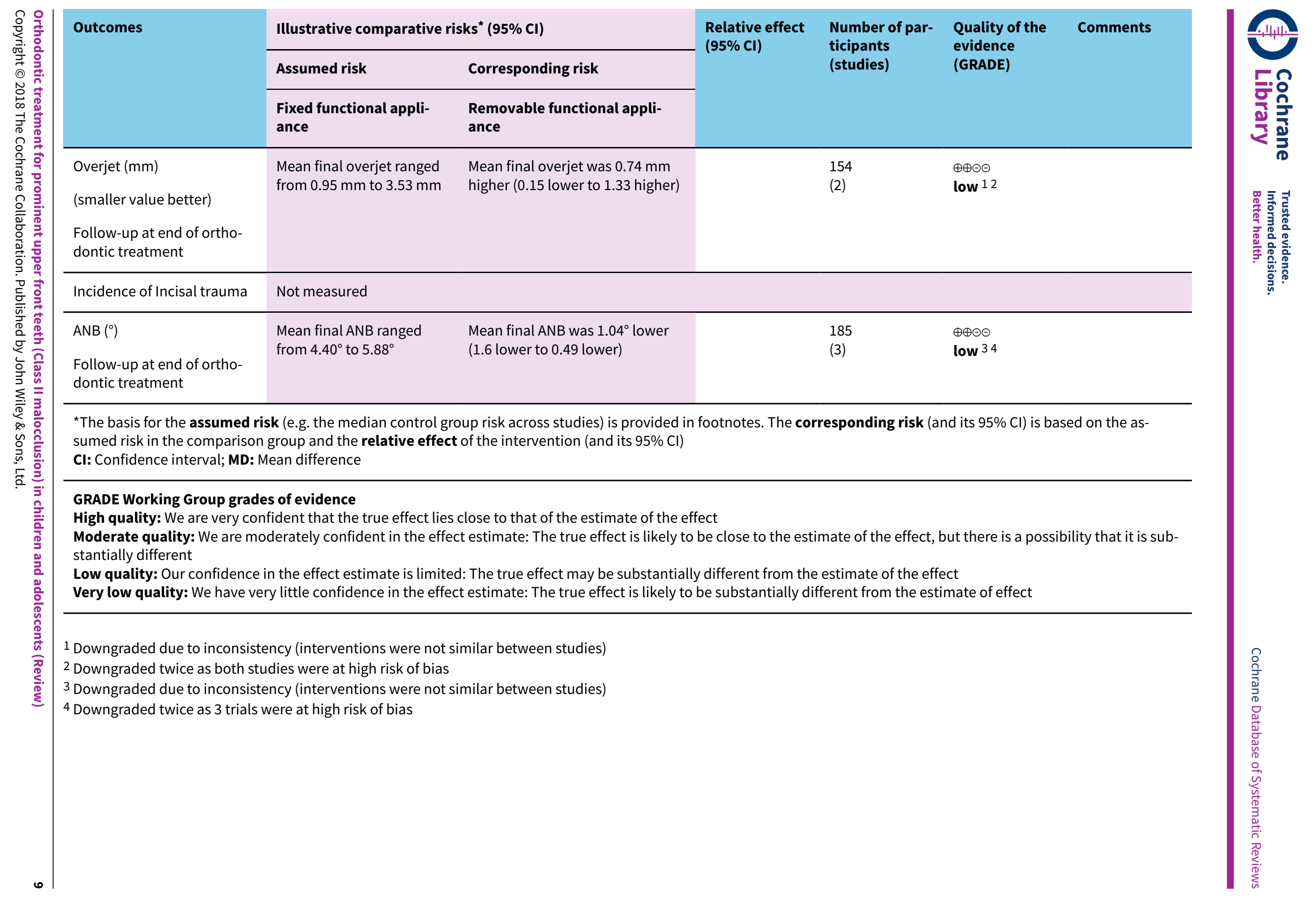




\section{B A C K G R O U N D}

\section{Description of the condition}

Orthodontics is the branch of dentistry concerned with the growth of the jaws and face, the development of the teeth and the way the teeth and jaws bite together. It also involves treatment of the teeth and jaws when they are irregular or bite in an abnormal way or both. There are many reasons why the teeth may not bite together correctly. These include the position of the teeth, jaws, lips, tongue, or cheeks; or may be due to heredity, a habit or the way people breathe. The need for orthodontic treatment can be decided by looking at the effect any particular tooth position has on the life expectancy of the teeth, or the effect that the appearance of the teeth has on how people feel about themselves, or both (Shaw 1991).

Prominent upper front teeth (Class II malocclusion) may be due to any combination of the jaw, tooth and lip position. The upper jaw (maxilla) can be too far forward or, more usually, the lower jaw (mandible) is too far back. The upper front teeth (incisors) may stick out if the lower lip catches behind them or due to a habit (e.g. thumb sucking). This gives the patient an appearance that may be a target for teasing (Shaw 1980) and bullying (Seehra 2011), which impacts on quality of life (Johal 2007; Silva 2016). When front teeth stick out (more than $3 \mathrm{~mm}$ to $5 \mathrm{~mm}$ ), they are two to three times more likely to be injured (Frujeri 2014; Nguyen 1999). Prominent upper front teeth (Class II malocclusion) is one of the most common problems seen by orthodontists and affects about a quarter of 12-year-old children in the UK (Holmes 1992). However, there are racial differences: prominent upper front teeth (Class II malocclusion) are most common in whites of Northern European origin and least common in black and oriental races and some Scandinavian populations (El-Mangoury 1990; Proffit 1993; Silva 2001).

\section{Description of the intervention}

Several dental brace (orthodontic) treatments have been suggested to correct prominent upper front teeth (Class II malocclusions). Some treatments aim to move the upper front teeth backwards (with or without the extraction of teeth) whilst others aim to modify the growth of the upper or lower jaw or both to reduce the prominence of the upper front teeth. Treatment can involve the use of one or more types of orthodontic brace.

\section{How the intervention might work}

Some braces apply a force directly to the teeth and can either be removed from the mouth or fixed to the teeth, with special glue, during treatment. Other types of brace are attached, via the teeth, to devices (headgear) that allow a force to be applied to the teeth and jaws from the back of the head. Treatment is usually carried out either early (early treatment), when a mixture of baby and adult teeth are present (around seven to 11 years of age) or later (adolescent treatment) when all the adult teeth have come into the mouth (around 12 to 16 years of age). In severe cases and some adults, orthodontic treatment may need to be combined with jaw surgery to correct the position of one or both jaws.

\section{Why it is important to do this review}

Cochrane Oral Health undertook an extensive prioritisation exercise in 2014 to identify a core portfolio of titles that were the most clinically important ones to maintain in the Cochrane Library (Worthington 2015). This review was identified as a priority title by the orthodontic expert panel (Cochrane OHG priority review portfolio).

The correction of prominent upper front teeth is one of the most common treatments performed by orthodontists. Even though we have several brace types to correct prominent upper front teeth, new braces are being introduced in the market to overcome the drawbacks of previous ones and there is a need to establish the relative effectiveness of the different braces that can be used. It is very important that we identify the most effective type of brace to give the best available treatment.

\section{OB JECTIVES}

To assess the effects of orthodontic treatment for prominent upper front teeth initiated when children are seven to 11 years old ('early treatment' in two phases) compared to in adolescence when they are around 12 to 16 years old ('late treatment' in one phase); to assess the effects of late treatment compared to no treatment; and to assess the effects of different types of orthodontic braces.

\section{METHODS}

\section{Criteria for considering studies for this review}

\section{Types of studies}

All randomised controlled trials of orthodontic treatments to correct prominent upper front teeth (Class II, Division 1 malocclusion).

\section{Types of participants}

Children (seven to 11 years old) and adolescents (usually 12 to 16 years old) receiving orthodontic treatment to correct prominent upper front teeth (Class II malocclusion).

We excluded trials including participants with a cleft lip or palate or both, or other craniofacial deformity/syndrome. We also excluded trials that recruited patients who had previously received surgical treatment for their Class II malocclusion.

\section{Types of interventions}

- Early treatment (two-phase) in childhood with any type of orthodontic brace (removable, fixed, functional) or head-brace compared with late treatment in adolescence (in one phase) with any type of orthodontic brace (removable, fixed, functional) or head-brace.

- Any type of orthodontic brace (removable, fixed, functional) or head-brace compared with no treatment or another type of orthodontic brace or appliance. For this comparison, treatment should have been started in children of similar ages in both groups.

\section{Types of outcome measures}

We recorded clinically important outcomes at the most common endpoints that were reported. If we identified harms, these were recorded and reported in descriptive terms. 


\section{Primary outcomes}

- Prominence of the upper front teeth (overjet measured in millimetres or by any index of malocclusion).

\section{Secondary outcomes}

- Relationship between upper and lower jaws measured, for example, by ANB angle.

- Self-esteem and patient satisfaction.

- Any injury to the upper front teeth (i.e. incisal trauma).

- Jaw joint problems.

- Number of attendances required to complete treatment.

- Harms such as health of the gums, damage to the teeth (e.g. tooth decay).

- Standard of orthodontic treatment.

\section{Search methods for identification of studies}

\section{Electronic searches}

Cochrane Oral Health's Information Specialist conducted systematic searches of the following databases for randomised controlled trials and controlled clinical trials. There were no language, publication year or publication status restrictions.

- Cochrane Oral Health's Trials Register (searched 27 September 2017) (Appendix 1).

- Cochrane Central Register of Controlled Trials (CENTRAL; 2017, Issue 8 ) in the Cochrane Library (searched 27 September 2017) (Appendix 2).

- MEDLINE Ovid (1946 to 27 September 2017) (Appendix 3).

- Embase Ovid (1980 to 27 September 2017) (Appendix 4).

Subject strategies were modelled on the search strategy designed for MEDLINE Ovid. Where appropriate, they were combined with subject strategy adaptations of the Highly Sensitive Search Strategy designed by Cochrane for identifying randomised controlled trials and controlled clinical trials as described in the Cochrane Handbook for Systematic Reviews of Interventions, Chapter 6 (Lefebvre 2011).

\section{Searching other resources}

The following trial registries were searched for ongoing studies:

- US National Institutes of Health Ongoing Trials Register (ClinicalTrials.gov; searched 29 September 2017) (Appendix 5).

- World Health Organization International Clinical Trials Registry Platform (apps.who.int/trialsearch; searched 29 September 2017) (Appendix 6).

We handsearched the following journals.

- Seminars in Orthodontics (from 1995 to December 2006).

- Clinical Orthodontics and Research (from 1998 to December 2001).

- Orthodontics \& Craniofacial Research (from 2001 to December 2006).

- Australian Orthodontic Journal (from 1956 to December 2006).

We checked the bibliographies of the clinical trials that we identified for references to trials published outside the handsearched journals, including personal references. We contacted the first named authors of all trial reports in an attempt to identify unpublished studies and to obtain any further information about the trials.

We searched the reference lists of included studies and relevant systematic reviews for further studies.

We did not perform a separate search for adverse effects of interventions used, we considered adverse effects described in included studies only.

\section{Data collection and analysis}

\section{Selection of studies}

Two review authors ( $\mathrm{KB}$ and $\mathrm{BT}$ or $\mathrm{BT}$ and $\mathrm{JH}$ ), independently and in duplicate, assessed the eligibility of all reports that were identified by the search strategy as being potentially relevant to the review. They were not blinded to author(s), institution or site of publication. Disagreements were resolved by discussion or following clarification from authors.

\section{Data extraction and management}

Two review authors (KB and $\mathrm{BT}$ or $\mathrm{BT}$ and $\mathrm{JH}$ ) extracted data (independently and in duplicate) using a specially designed data extraction form. We recorded the year of publication, interventions assessed, outcomes, sample size and age of subjects. We grouped the outcome data into those measured at the end of treatment provided for young children and at the end of treatment provided for adolescent children.

\section{Assessment of risk of bias in included studies}

This was conducted using the recommended approach for assessing risk of bias in studies included in Cochrane Reviews (Higgins 2011). We used the two-part tool, addressing six specific domains (namely sequence generation; allocation concealment; blinding of outcome assessors; incomplete outcome data; selective outcome reporting; and other bias). Each domain included one specific entry in a 'Risk of bias' table. Within each entry, the first part of the tool involved describing what was reported to have happened in the study. The second part of the tool involved assigning a judgement relating to the risk of bias for that entry, either 'low risk', 'high risk' or, where there was insufficient information on which to base a judgement, 'unclear risk'.

The risk of bias assessments were undertaken independently and in duplicate by two review authors (KB and BT or BT and $\mathrm{JH}$ ) as part of the data extraction process with assistance from Cochrane Oral Health when necessary.

After taking into account the additional information provided by the authors of the trials, we grouped studies into the following categories.

- Low risk of bias (plausible bias unlikely to seriously alter the results) if all key domains were assessed as low.

- Unclear risk of bias (plausible bias that raises some doubt about the results) if one or more key domains were assessed as unclear.

- High risk of bias (plausible bias that seriously weakens confidence in the results) if one or more key domains were assessed to be at high risk of bias. 
A 'Risk of bias' table was completed for each included study and results were presented graphically.

\section{Measures of treatment effect}

For dichotomous outcomes, we expressed the estimates of effect of an intervention as odds ratios together with $95 \%$ confidence intervals (Cls). For continuous outcomes, we used mean differences, together with $95 \% \mathrm{Cls}$, to summarise the data for each group.

\section{Assessment of heterogeneity}

The significance of any discrepancies in the estimates of the treatment effects from the different trials was assessed by means of Cochrane's test for heterogeneity and the $\mathrm{I}^{2}$ statistic, which describes the percentage total variation across studies that is due to heterogeneity rather than chance.

\section{Data synthesis}

We performed meta-analysis only if there were studies with similar comparisons that reported the same outcome measures. We combined odds ratios for dichotomous data, and mean differences for continuous data, using random-effects models if there were four or more studies in the meta-analysis, and fixed-effect models if there were up to three studies.

\section{Subgroup analysis and investigation of heterogeneity}

We assessed clinical heterogeneity by examining the types of participants and interventions for all outcomes in each study.

\section{Sensitivity analysis}

We had planned to undertake sensitivity analyses to examine the effect of the study risk of bias assessment on the overall estimates of effect. In addition, we planned to examine the effect of including unpublished literature, but there were insufficient trials to undertake this.

\section{Summarising findings}

We created 'Summary of findings' (SoF) tables to record results of the main outcomes (overjet, incisal trauma and ANB) for the main comparisons: early treatment using a functional appliance versus late treatment; early treatment using headgear versus late treatment; late treatment with functional appliances versus no treatment; late treatment with different appliances (two tables). We assessed the quality of the evidence using GRADE.

\section{RES U L T S}

\section{Description of studies}

\section{Results of the search}

The initial review was published in 2007. Searches to date (September 2017) have identified a total of 2319 records (910 after duplicates removed), of which we assessed 181 records in full text. Of these 181 records, we excluded 104 articles and we considered a further 14 irrelevant. Twenty-seven trials (published in 63 papers) met the inclusion criteria. See Figure 1. 
Figure 1. Study flow diagram

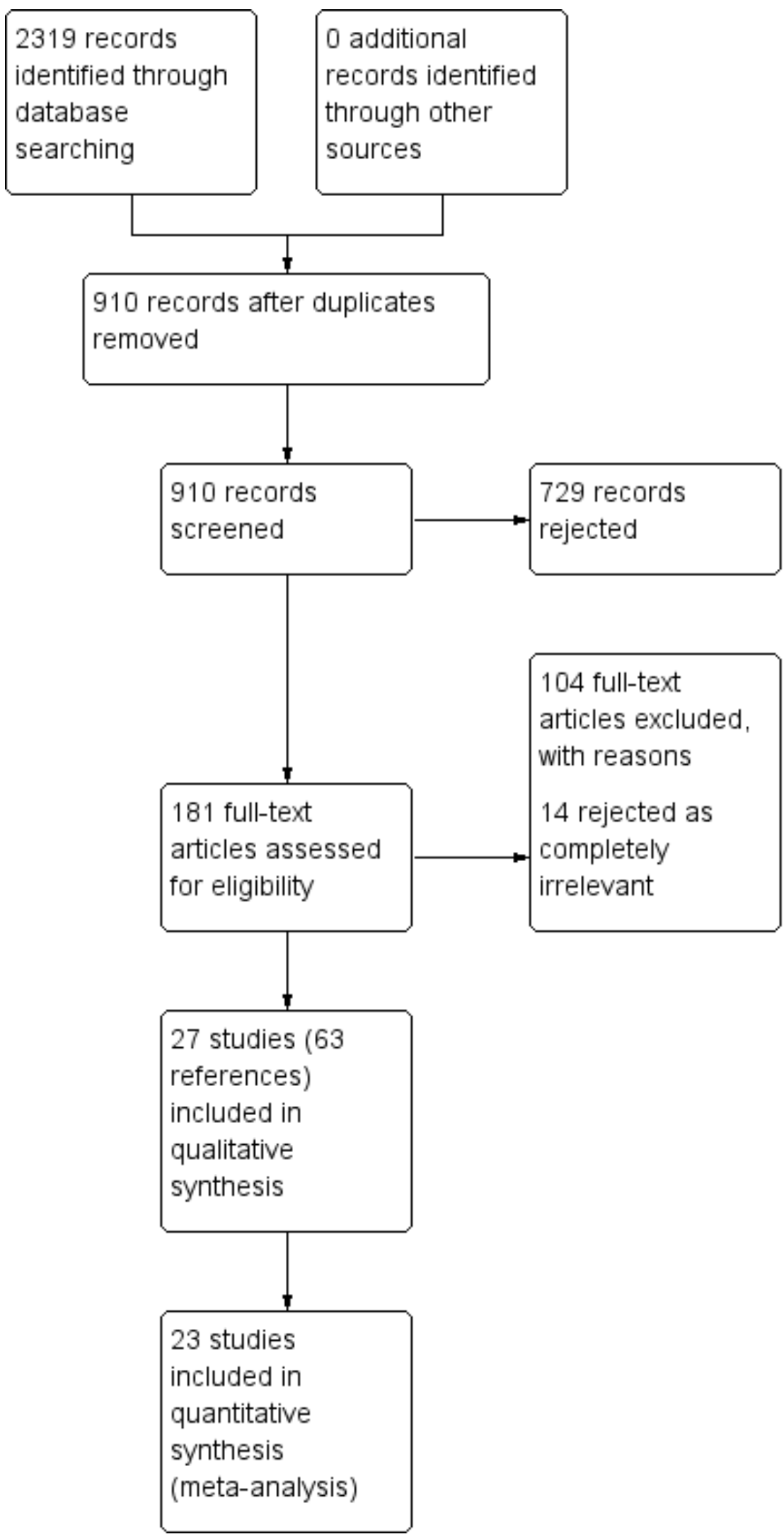




\section{Included studies}

See Characteristics of included studies table for details of included studies.

\section{Characteristics of the trial settings and investigators}

Of the 27 included trials, seven were conducted in the United Kingdom (Banks 2004; Lee 2007; London 1998; Thiruvenkatachari 2010; UK (11-14) 2003; UK (Mixed) 2009; Yaqoob 2012); three were carried out in North America (Florida 1998; Ghafari 1998; North Carolina 2004); two were conducted in China (Mao 1997; Jin 2015); one in New Zealand (New Zealand 2000); one in Australia (Bilgiç 2011); four in Turkey (Aras 2017a; Aras 2017b; Cura 1997; Baysal 2014); two in Iran (Jamilian 2011; Showkatbakhsh 2011); two in Syria (Alali 2014; Burhan 2015); one in Brazil (Cevidanes 2003); one in Italy (Martina 2013); two in Egypt (Eissa 2017; Elkordy 2016); and one in Sweden (Cirgić 2016). All trials had a parallel-group design. Five were multicentre studies (Banks 2004; Thiruvenkatachari 2010; UK (11-14) 2003; UK (Mixed) 2009; Cirgić 2016). Eleven of the trials had more than one publication. Seven of the trials received external funding. The providers and assessors were dental staff.

\section{Characteristics of the participants}

For the 27 trials included in the review, the results are based on data from 1251 participants who presented with prominent upper front teeth (Class II Division 1 malocclusion). The number of participants in each treatment or control group ranged from 12 to 105.

Four trials provided treatment for children aged between 7 and 11 years old (Florida 1998; Ghafari 1998; North Carolina 2004; UK (Mixed) 2009). One trial provided treatment for children who were 7 to 14 years old (Cirgić 2016). Two trials provided treatment for children aged between 8 and 11 years (Mao 1997; Showkatbakhsh 2011). Three trials provided treatment for children aged between 9 and 13 years old (Cevidanes 2003; Jamilian 2011; Martina 2013). One trial provided treatment for children who were 10 to 13 years old (New Zealand 2000). Twenty provided treatment for children who were 10 to 15 years old (Alali 2014; Aras 2017a; Aras 2017b; Banks 2004; Baysal 2014; Burhan 2015; Bilgiç 2011; Cura 1997; Eissa 2017; Elkordy 2016; Jin 2015; Lee 2007; London 1998; Thiruvenkatachari 2010; UK (11-14) 2003; Yaqoob 2012).

Two of the trials had an active recruitment strategy that involved screening school children and providing incentives, such as reduced fees for participation (Florida 1998; North Carolina 2004).

The percentage of participants lost to follow-up varied from $0 \%$ to $26 \%$.

\section{Characteristics of the intervention}

All of the trials provided a clear description of the treatment protocols.

We classified the interventions for the treatment of Class II malocclusion as follows.

\section{Early treatment (two-phase) for Class II Division 1 malocclusion}

- There were three trials that compared early treatment (twophase) with late treatment (one-phase) (Florida 1998; North Carolina 2004; UK (Mixed) 2009).

- Three trials compared two different types of appliances for early treatment (Florida 1998; Ghafari 1998; North Carolina 2004).
In this group of trials, treatment of Class II division 1 malocclusion started when participants were aged nine years and comprised two treatment phases. In phase one, participants were randomised to receive one of two types of appliance or to a control group that received no early treatment. When phase one of the trials was completed, participants who had early treatment had a second phase of treatment, and participants who were in the no treatment group had one single phase of adolescent treatment. Outcome measures were compared between those who had received both early and late treatment and those who received late treatment only.

\section{Late treatment in adolescence (one-phase) for Class II Division 1 malocclusion}

- Nine trials compared functional appliances with no treatment (Alali 2014; Baysal 2014; Cevidanes 2003; Cura 1997; Eissa 2017; Elkordy 2016; Mao 1997; Martina 2013; New Zealand 2000). As Baysal 2014 did not randomise participants to the 'no treatment' arm, we did not include their results for the functional versus no treatment comparison.

- Eighteen trials compared different types of appliances.

- Twin Block appliances were compared with other types of appliances in eight trials (Baysal 2014; Burhan 2015; Jamilian 2011; Jin 2015; Lee 2007; London 1998; Thiruvenkatachari 2010; UK (11-14) 2003).

- Twin Block appliances were compared with various modifications to twin blocks in two trials (Banks 2004; Yaqoob 2012).

- Andresen activator was compared with a prefabricated functional appliance in one trial (Cirgic 2016).

- Forsus Fatigue Resistance Device was compared to Forsus Fatigue Resistance Device and mini-implants in two trials (Eissa 2017; Elkordy 2016).

- R-appliance was compared with Anterior Inclined Bite Plate in one trial (Showkatbakhsh 2011).

- Removable functional appliances were compared to fixed functional appliances in three trials (Baysal 2014; Bilgiç 2011; UK (11-14) 2003).

- Forsus Fatigue Resistance Device was compared with intermaxillary elastics in one trial (Aras 2017b).

- Functional mandibular advancer was compared for stepwise versus single step advancement (Aras 2017a).

- Harvold Activator was compared with Frankel function regulator (New Zealand 2000)

\section{Outcome measures in the included studies}

The primary outcome measure was the prominence of the upper front teeth (overjet measured in millimetres or by any index of malocclusion), and this was included in all studies. We also measured the relationship between upper and lower jaws (ANB angle measured in degrees), self-esteem and patient satisfaction (measured using reported questionnaires), any injury to the upper front teeth, jaw joint problems, number of attendances required to complete treatment, harms to gums, damage to the teeth and the standard of orthodontic treatment (measured using PAR scores - Peer Assessment Rating index). The majority of the studies presented results for late orthodontic treatment in adolescence. Three trials reported on final overjet, final ANB, final PAR score and incidence of new incisal trauma for early treatment (Florida 
1998; North Carolina 2004; UK (Mixed) 2009). One trial reported selfconcept in early treatment (UK (Mixed) 2009).

\section{Excluded studies}

We excluded 104 studies. The main reasons for exclusion were as follows. See Characteristics of excluded studies table for further details.

- 85 were not RCTs;

- 4 had only abstracts and did not have sufficient information to determine whether they met the inclusion criteria of the review;

- 4 did not involve treatment of people with a Class II Division 1 malocclusion (or they were only a small proportion of participants);

- 4 included Class II division 2 participants;

- 5 included adults;

- 1 had no information on overjet and ANB;

- 1 was imaging study of TMJ.

\section{Risk of bias in included studies}

\section{Allocation}

\section{Sequence generation}

In 16 studies (Aras 2017a; Aras 2017b; Banks 2004; Baysal 2014; Burhan 2015; Eissa 2017; Elkordy 2016; Jamilian 2011; Jin 2015; Martina 2013; North Carolina 2004; Showkatbakhsh 2011; Thiruvenkatachari 2010; UK (11-14) 2003; UK (Mixed) 2009; Yaqoob 2012), the method of random sequence generation was clearly described and these studies were assessed as being at low risk of bias for this domain. Ten of these studies used minimisation software as a method of sequence generation (Aras 2017a; Aras 2017b; Banks 2004; Burhan 2015; Eissa 2017; Elkordy 2016; Martina 2013; Thiruvenkatachari 2010; UK (11-14) 2003; UK (Mixed) 2009). One study used stratified block randomisation (Yaqoob 2012), four studies used random number tables (Baysal 2014; Jamilian 2011; Jin 2015; Showkatbakhsh 2011) and one used Proc plan in SAS (North Carolina 2004). Nine studies did not report on the method of random sequence generation and were judged at unclear risk of bias (Alali 2014; Cevidanes 2003; Cirgić 2016; Cura 1997; Ghafari 1998; Lee 2007; London 1998; Mao 1997; New Zealand 2000). Two studies were judged to be at high risk of bias (Bilgiç 2011; Florida 1998). Florida 1998 reported an inadequate method of randomisation, filling up the partially filled blocks in stratified block randomisation due to slow rate of entry. Bilgiç 2011 reported that participants were selected and matched between groups according to the inclusion criteria. Additionally, they did not report the method of random sequence generation.

\section{Allocation concealment}

In eight studies (Banks 2004; Eissa 2017; Elkordy 2016; Martina 2013; Thiruvenkatachari 2010; UK (11-14) 2003; UK (Mixed) 2009; Yaqoob 2012), allocation concealment was clearly described and therefore these studies were judged at low risk of bias for this domain. Eighteen studies did not report any information about allocation concealment and were assessed as being at unclear risk of bias for this domain (Aras 2017a; Aras 2017b; Alali 2014; Baysal 2014; Bilgiç 2011; Burhan 2015; Cevidanes 2003; Cirgić 2016; Cura 1997; Florida 1998; Ghafari 1998; Jamilian 2011; Jin 2015; Lee 2007; London 1998; Mao 1997; North Carolina 2004; Showkatbakhsh 2011). One study reported that randomisation was matched in triads according to age and sex and randomly assigned to the three intervention groups (New Zealand 2000). It is possible that allocation could be predictable within the triad time. As a result, we felt that this study was at high risk of bias for this domain (New Zealand 2000).

\section{Blinding}

Blind assessment of all outcomes was reported in 13 studies and these were assessed as at low risk of bias (Aras 2017a; Aras 2017b; Alali 2014; Banks 2004; Burhan 2015; Cevidanes 2003; Elkordy 2016; Florida 1998; Jamilian 2011; Martina 2013; UK (11-14) 2003; UK (Mixed) 2009; Yaqoob 2012). Blind outcome assessment was not reported in 10 studies and they were judged at unclear risk of bias (Bilgiç 2011; Cura 1997; Eissa 2017; Ghafari 1998; Jin 2015; Lee 2007; London 1998; Mao 1997; New Zealand 2000; Showkatbakhsh 2011). An additional study reported clinical measures only and blinding was not possible. This was judged to be at unclear risk of bias (Thiruvenkatachari 2010). Three studies stated that the assessors were not blinded and were judged at high risk of bias (Baysal 2014; Cirgić 2016; North Carolina 2004).

\section{Incomplete outcome data}

Trials of orthodontic treatment for Class II division 1 malocclusion typically last for at least five or more years and consequently there is a high rate of attrition, some of which is related to the orthodontic treatment offered, and some due to factors such as families moving to a different area. Attrition rates in the studies included in this review ranged from $6 \%$ to $28 \%$ of participants initially randomised to treatments. In assessing risk of attrition bias, we looked at the overall rate of attrition in the study, the relative loss for each arm of each study and the reasons given to explain these.

We assessed 11 studies as being at low risk of attrition bias (Aras 2017a; Aras 2017b; Baysal 2014; Bilgiç 2011; Burhan 2015; Jamilian 2011; Jin 2015; Lee 2007; Showkatbakhsh 2011; UK (Mixed) 2009; Yaqoob 2012). UK (Mixed) 2009 had high overall attrition (19\%) but the reasons given and the numbers were similar in each treatment arm and we considered that attrition bias was unlikely. Yaqoob 2012 had low overall attrition (6\%) and reasons and numbers were similar in each treatment arm.

A further eight studies were assessed as being at unclear risk of attrition bias (Alali 2014; Cirgić 2016; Cevidanes 2003; Eissa 2017; Elkordy 2016; Mao 1997; North Carolina 2004; Thiruvenkatachari 2010). In two of these studies (Cevidanes 2003; North Carolina 2004), the overall rate of attrition was $10 \%$ to $19 \%$, but there was incomplete information on the rates and reasons for participants being excluded from the analysis in each treatment group within the study. In Alali 2014 the overall rate of attrition was 13\% but there were more dropouts in the treatment (four participants, 16\%) than in the control group (one participant, 5\%). Mao 1997 provided no information about the number of participants included in the outcome evaluation. The study by Thiruvenkatachari 2010 was stopped early and had more than twice as many participants lost from the Twin Block treatment group compared to the Dynamax group. One study reported $46 \%$ attrition rate for one of the outcomes measured (Cirgić 2016). Cirgić 2016 also presented an imbalance between the treated groups with 43 participants analysed in one group and 62 in the other group. One study reported uneven dropout rates between groups and was therefore judged as unclear risk (Eissa 2017). In Elkordy 2016 there was no 
loss in the treated groups, but there was a loss of $20 \%$ in the control group.

We assessed the remaining eight studies as being at high risk of attrition bias (Banks 2004; Cura 1997; Florida 1998; Ghafari 1998; London 1998; Martina 2013; New Zealand 2000; UK (11-14) 2003). Seven of these studies had more than $20 \%$ attrition and a significant difference in the rate and reason for participants being excluded from the analysis in each arm of the study (Banks 2004; Cura 1997; Florida 1998; Ghafari 1998; London 1998; Martina 2013; New Zealand 2000). UK (11-14) 2003 had a lower overall attrition rate of $15 \%$ but the dropout rate was significantly different between groups.

\section{Selective reporting}

Twenty-four studies reported all of the outcomes specified in the methodology and were judged at low risk of reporting bias (Alali 2014; Aras 2017a; Aras 2017b; Banks 2004; Baysal 2014; Bilgiç 2011; Burhan 2015; Cirgić 2016; Cura 1997; Eissa 2017; Elkordy 2016; Florida 1998; Ghafari 1998; Jamilian 2011; Jin 2015; Lee 2007; London 1998; Martina 2013; New Zealand 2000; North Carolina 2004; Thiruvenkatachari 2010; UK (11-14) 2003; UK (Mixed) 2009; Yaqoob 2012). One study reported only on a few cephalometric measurements and no clinical measurements so was judged to be at unclear risk of bias (Showkatbakhsh 2011). One study used a complicated reporting method from which data could not be extracted for meta-analysis and this study was judged at unclear risk of reporting bias (Cevidanes 2003). The study by Mao 1997 had reported data, but these were not clear and data could not be extracted for meta-analysis, so this study was also assessed at unclear risk of reporting bias.

\section{Other potential sources of bias}

There was no other potential source of bias identified in 18 studies and these were judged to be at low risk of bias (Aras 2017a; Alali 2014; Banks 2004; Baysal 2014; Bilgiç 2011; Burhan 2015; Eissa 2017; Florida 1998; Ghafari 1998; Jamilian 2011; Jin 2015; Martina 2013; New Zealand 2000; North Carolina 2004; Showkatbakhsh 2011; UK (11-14) 2003; UK (Mixed) 2009; Yaqoob 2012).
Five studies were judged as being at unclear risk of other bias (Cevidanes 2003; Cirgić 2016; Elkordy 2016; Lee 2007; London 1998). One study did not report baseline characteristics of the groups (Cevidanes 2003). One study did not present the age of participants at baseline (Cirgić 2016). The sample of one study had only females (Elkordy 2016). One study had differences in age at baseline between randomised groups. Although this was not statistically significant (which may be due to small numbers in each group), this study was assessed as at unclear risk of other bias (London 1998). Two studies found a higher incidence of appliance breakages in the Dynamax group than in the Twin Block group (Lee 2007; Thiruvenkatachari 2010). Cirgić 2016 stopped recruitment midway and therefore had uneven numbers between groups.

Four studies were assessed at high risk of other bias (Aras 2017b; Cura 1997; Mao 1997; Thiruvenkatachari 2010). Cura 1997 and Aras 2017b had gender imbalance at baseline between groups, which may have led to a bias due to the different responses of boys and girls to orthodontic treatment. Mao 1997 did not report data clearly and also had gender imbalance between groups at baseline (Bionator group 18 males, six females and untreated group nine males and 17 females). One study stopped prematurely due to excessive adverse events and a statistically significant difference between groups at the first interim analysis and so was assessed to be at high risk of bias (Thiruvenkatachari 2010).

\section{Overall risk of bias}

In summary, 15 studies were considered to be at high risk of bias in at least one domain and were therefore assessed to be at high risk of bias overall (Aras 2017b; Banks 2004; Baysal 2014; Bilgiç 2011; Cirgić 2016; Cura 1997; Florida 1998; Ghafari 1998; London 1998; Mao 1997; Martina 2013; New Zealand 2000; North Carolina 2004; Thiruvenkatachari 2010; UK (11-14) 2003); two studies were considered to be at low overall risk of bias (UK (Mixed) 2009; Yaqoob 2012); and 10 studies at unclear overall risk of bias (Aras 2017a; Alali 2014; Burhan 2015; Cevidanes 2003; Eissa 2017; Elkordy 2016; Jamilian 2011; Jin 2015; Lee 2007; Showkatbakhsh 2011) (Figure 2). 
Figure 2. Risk of bias summary: review authors' judgements about each risk of bias item for each included study.

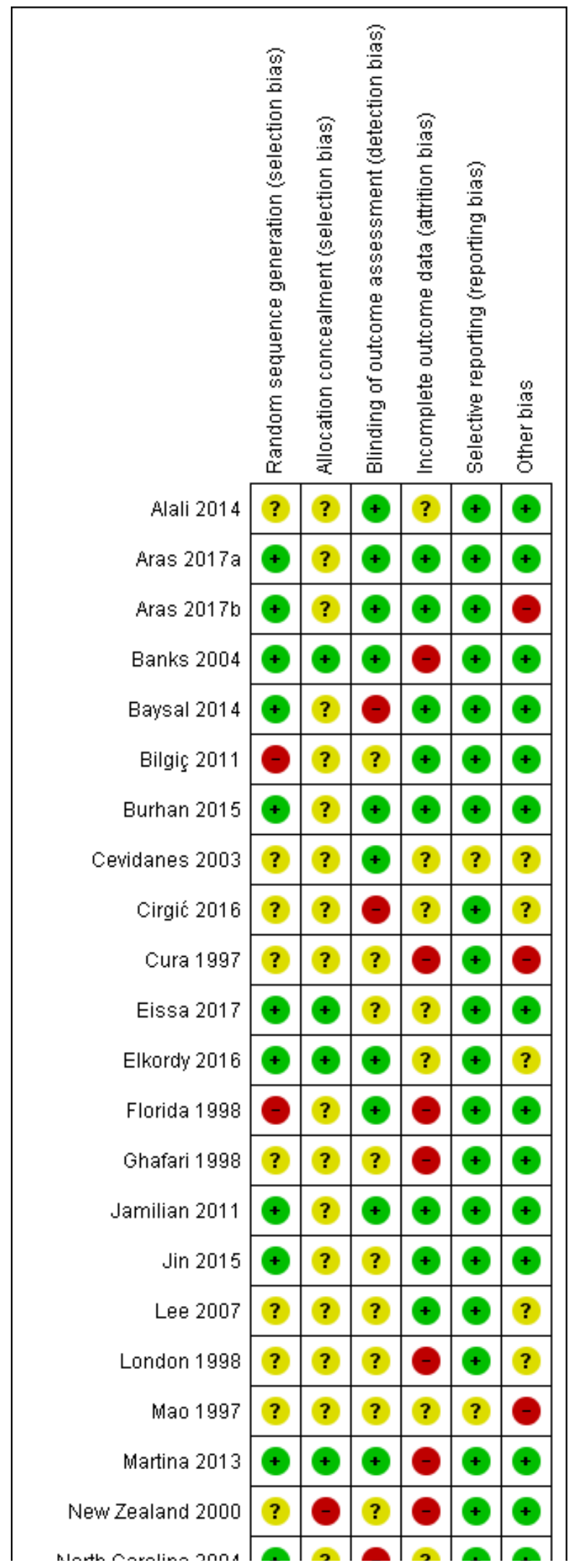


Figure 2. (Continued)

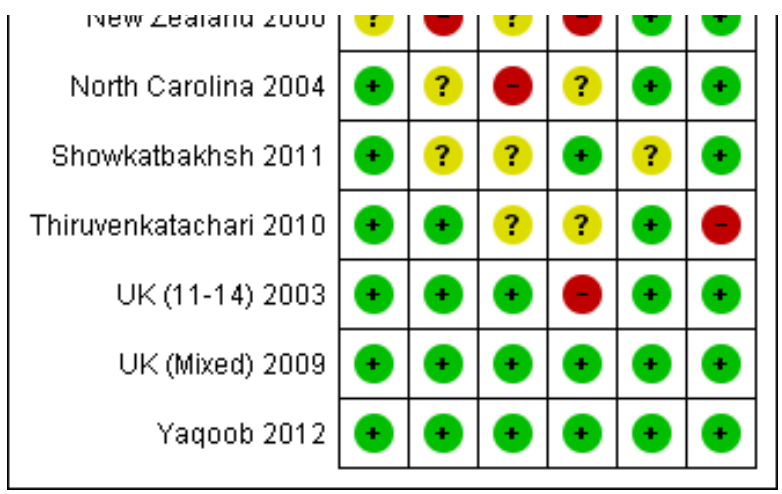

\section{Effects of interventions}

See: Summary of findings for the main comparison Early treatment (two-phase: phase one in childhood and phase two in adolescence) versus late treatment (one-phase in adolescence) with functional appliance; Summary of findings 2 Early treatment (two-phase: phase 1 in childhood and phase 2 in adolescence) with headgear appliance versus late treatment (one-phase in adolescence) with headgear; Summary of findings 3 Late treatment (one-phase in adolescence) with functional appliance versus no treatment for prominent upper front teeth (Class II malocclusion); Summary of findings 4 Late treatment (onephase in adolescence): comparison among different types of appliances used for treatment of prominent upper front teeth (Class II malocclusion); Summary of findings $\mathbf{5}$ Late treatment (one-phase in adolescence): comparison among different types of appliances used for treatment of prominent upper front teeth (Class II malocclusion)

We divided the trials into two main groups.

- Early orthodontic treatment for Class II Division 1 malocclusion.

a. Comparison 1: early treatment (two-phase: phase one in childhood ( 7 to 11 years) and phase two in adolescence (12 to 16 years)) versus late treatment (one-phase in adolescence).

i. Outcomes at the end of phase one (Comparisons 1.1 to 1.4).

ii. Outcomes at the end of phase two (Comparisons 1.5 to 1.8).

b. Comparison 2: early orthodontic treatment (two-phase): different types of appliances.

i. Outcomes at the end of phase one (Comparisons 2.1 and 2.2).

ii. Outcomes at the end of phase two (Comparisons 2.3 and 2.4).

- Late orthodontic treatment in adolescence (one-phase) for Class II Division 1 malocclusion.

a. Comparison 3: late treatment in adolescence with functional appliances versus no treatment (Comparison 3.1).

b. Comparison 4: different types of appliances used for late treatment in adolescence (Comparisons 4.1 to 4.10).

Four studies were not included in meta-analysis (Cevidanes 2003; Ghafari 1998; Lee 2007; Thiruvenkatachari 2010).
Cevidanes 2003 looked at the effects of functional appliances (Frankel appliance) on the temporomandibular joint. This study did not carry out any dental measurements and therefore had no data to contribute to the meta-analysis.

Ghafari 1998 did not publish data at the end of the study. Partial presentation of data in several interim publications could not be included in the analysis.

Lee 2007 reported medians and interquartile range and these nonparametric data could not be used in the meta-analysis. However, this study reported that there was no difference in overjet change between Twin Block and Dynamax appliances.

Thiruvenkatachari 2010 stopped this trial early due to harms. The incidence of adverse events with the Dynamax appliance (82\%) was significantly greater than the Twin Block appliance $(12 \%)$ ( $P$ value < 0.001 ) and the Twin Block appliance was more effective for overjet reduction. However, insufficient data were available to be used in the meta-analysis.

\section{Early orthodontic treatment (two-phase) for Class II division 1 malocclusion}

\section{Early treatment (two-phase) versus late treatment in adolescence (one-phase)}

\section{Outcomes at the end of phase one}

\section{Treatment with functional appliance}

Three trials (two at high risk of bias, one at low risk of bias) compared early treatment (two-phase) using a functional appliance, with late treatment in adolescence (one-phase) (Florida 1998; North Carolina 2004; UK (Mixed) 2009). Data were available comparing outcomes at the end of phase one for the early treatment group with observation only in the late treatment group. The meta-analysis showed that there was a statistically significant difference in the overjet in favour of the treated group at the end of phase one (mean difference (MD) $-4.17 \mathrm{~mm}, 95 \%$ confidence interval $(\mathrm{Cl})-4.61$ to $-3.73, \mathrm{Chi}^{2}=117.02,2$ degrees of freedom (df), $P$ value $<0.00001, I^{2}=98 \%$; three studies, 432 participants) (Analysis 1.1).

When we evaluated the effect of treatment on final ANB, we found that there was a statistically significant mean difference between the treatment and control groups in favour of functional appliance treatment (MD $-0.89^{\circ} ; 95 \% \mathrm{Cl}-1.38^{\circ}$ to $-0.40^{\circ}, \mathrm{Chi}^{2}=9.17,2 \mathrm{df}, \mathrm{P}$ value $=0.0004, \mathrm{I}^{2}=78 \%$; three studies, 419 participants $)$. 
There was also a statistically significant effect on the PAR score in favour of early treatment $\left(\mathrm{MD}-10.52,95 \% \mathrm{Cl}-12.32\right.$ to $-8.71, \mathrm{Chi}^{2}=$ $52.23,2 \mathrm{df}$, $P$ value $<0.00001, I^{2}=98 \%$; two studies, 249 participants) (Analysis 1.1).

Early treatment did not show any significant difference in selfconcept score (MD $-3.63,95 \% \mathrm{Cl}-7.66$ to $0.40, \mathrm{P}$ value $=0.08$; one study, 135 participants) (Analysis 1.1); and incidence of new incisal trauma at the end of phase 1 (odds ratio (OR) $0.72,95 \% \mathrm{Cl} 0.35$ to 1.49 , $P$ value $=0.38$; two trials, 281 participants) (Analysis 1.2) when compared with untreated control group participants.

\section{Treatment with headgear}

Two trials, both at high risk of bias, compared early treatment (two-phase), using headgear, with late treatment in adolescence (one-phase) (Florida 1998; North Carolina 2004). The comparison of the effect of treatment with headgear at the end of phase one (early treatment group), compared with observation (late treatment group), revealed a statistically significant effect of headgear treatment, in the reduction of the overjet (MD $-1.07 \mathrm{~mm}$, $95 \% \mathrm{Cl}-1.63 \mathrm{~mm}$ to $-0.51 \mathrm{~mm}, \mathrm{Chi}^{2}=0.05,1 \mathrm{df}, \mathrm{P}$ value $=0.0002, \mathrm{I}^{2}=$ $0 \% ; 278$ participants) (Analysis 1.3). Similarly, headgear resulted in a statistically significant reduction of $-0.72^{\circ}\left(95 \% \mathrm{Cl}-1.18^{\circ}\right.$ to $-0.27^{\circ}$, $\mathrm{Chi}^{2}=0.34,1 \mathrm{df}$, $\mathrm{P}$ value $=0.002, \mathrm{I}^{2}=0 \% ; 277$ participants) in final ANB (Analysis 1.3). However, there was no statistically significant difference in new incisal trauma (OR $0.76,95 \% \mathrm{Cl} 0.37$ to $1.54, \mathrm{Chi}^{2}=$ $0.66,1 \mathrm{df}, \mathrm{P}$ value $=0.44, \mathrm{I}^{2}=0 \%$ ) between the two groups (Analysis 1.4).

\section{Outcomes at the end of phase two}

\section{Treatment with functional appliance}

Three trials (two at high risk of bias, one at low risk of bias) compared early treatment (two-phase) with a functional appliance versus late treatment in adolescence (Florida 1998; North Carolina 2004; UK (Mixed) 2009). When we evaluated the effects of a course of treatment for children (one-phase) with a functional appliance and at the end of all orthodontic treatment during adolescence (one-phase), we found that there were no statistically significant differences in final overjet (MD $0.21 \mathrm{~mm}, 95 \% \mathrm{Cl}-0.10 \mathrm{~mm}$ to 0.51 $\mathrm{mm}, \mathrm{Chi}^{2}=5.23,2 \mathrm{df}, \mathrm{P}$ value $=0.18, \mathrm{I}^{2}=62 \% ; 343$ participants) (Analysis 1.5), final ANB (MD $-0.02^{\circ} ; 95 \% \mathrm{Cl}-0.47^{\circ}$ to $0.43^{\circ}, \mathrm{Chi}^{2}=$ $2.62,2 \mathrm{df}, \mathrm{P}$ value $=0.92, \mathrm{I}^{2}=24 \% ; 347$ participants) (Analysis 1.5), PAR score (MD $0.62,95 \% \mathrm{Cl}-0.66$ to $1.91, \mathrm{Chi}^{2}=6.43,2 \mathrm{df}, \mathrm{P}$ value $=0.34, \mathrm{I}^{2}=69 \% ; 360$ participants) (Analysis 1.5), or self-concept score $(\mathrm{MD}-0.83,95 \% \mathrm{Cl}-3.97$ to $2.31, \mathrm{P}$ value $=0.60$; one study, 132 participants). However, the incidence of new incisal trauma showed a statistically significant difference, in favour of early functional appliance treatment in childhood (two-phase) (OR 0.56, 95\% Cl 0.33 to $0.95, \mathrm{Chi}^{2}=1.98,2 \mathrm{df}, \mathrm{P}$ value $=0.03, \mathrm{I}^{2}=0 \%$; 332 participants) (Analysis 1.6) compared with late orthodontic treatment during adolescence (one-phase). The reduction in the incidence of new incisal trauma by the end of phase two was clinically significant with $30 \%(51 / 171)$ of participants reporting new trauma incidence in the late treatment group compared to only $19 \%(31 / 161)$ in the early treatment group.

\section{Treatment with headgear when younger}

Two trials, both at high risk of bias, compared early treatment (two-phase), using headgear, with late treatment in adolescence (one-phase) (Florida 1998; North Carolina 2004). There were no statistically significant effects of an early course of headgear treatment in childhood followed by treatment in adolescence with respect to final overjet (MD $-0.22 \mathrm{~mm}, 95 \% \mathrm{Cl}-0.56 \mathrm{~mm}$ to 0.12 $\mathrm{mm}, \mathrm{Chi}^{2}=1.27,1 \mathrm{df}, \mathrm{P}$ value $=0.20, \mathrm{I}^{2}=21 \% ; 238$ participants) (Analysis 1.7), final ANB (MD $-0.27^{\circ}, 95 \% \mathrm{Cl}-0.80^{\circ}$ to $0.26^{\circ}, \mathrm{Chi}^{2}=$ $0.10,1 \mathrm{df}, \mathrm{P}$ value $=0.32, \mathrm{I}^{2}=0 \% ; 231$ participants) (Analysis 1.7), or PAR score (MD $-1.55,95 \% \mathrm{Cl}-3.70$ to $0.60, \mathrm{Chi}^{2}=0.39,1 \mathrm{df}$, P value $=0.16, \mathrm{I}^{2}=0 \% ; 177$ participants) (Analysis 1.7 ) compared with one phase of treatment in adolescence. However, the incidence of new incisal trauma showed a statistically significant reduction in the earlier treatment (two-phase) group (OR $0.45,95 \% \mathrm{Cl} 0.25$ to 0.80 , $\mathrm{Chi}^{2}=1.15,1 \mathrm{df}, \mathrm{P}$ value $=0.007, \mathrm{I}^{2}=13 \% ; 237$ participants) (Analysis 1.8). The group who had late treatment in adolescence (one-phase) suffered twice the incidence of new incisal trauma (44/120) as compared to the group who had early headgear treatment (twophase) in childhood (24/117).

\section{Early orthodontic treatment in children (two-phase): different types of appliances}

\section{Outcomes at the end of phase one}

Two trials, at high risk of bias, compared the use of different types of appliances (headgear and functional appliance) for early treatment (two-phase) (Florida 1998; North Carolina 2004). When we compared the effects of treatment with headgear or functional appliances in children, we found statistically significant differences with respect to final overjet (MD $0.75 \mathrm{~mm}, 95 \% \mathrm{Cl} 0.21 \mathrm{~mm}$ to 1.29 $\mathrm{mm}, \mathrm{Chi}^{2}=12.54,1 \mathrm{df}, \mathrm{P}$ value $=0.006, \mathrm{I}^{2}=92 \% ; 271$ participants) (Analysis 2.1) in favour of functional appliances, but no difference in final ANB (MD $-0.04^{\circ}, 95 \% \mathrm{Cl}-0.49^{\circ}$ to $0.41^{\circ}, \mathrm{Chi}^{2}=0.03,1 \mathrm{df}, \mathrm{P}$ value $=0.85, \mathrm{I}^{2}=0 \% ; 271$ participants) (Analysis 2.1), or new incisal trauma (OR $1.02,95 \% \mathrm{Cl} 0.48$ to $2.17, \mathrm{Chi}^{2}=0.22,1 \mathrm{df}, \mathrm{P}$ value $=0.95$, $\mathrm{I}^{2}=0 \% ; 282$ participants) (Analysis 2.2).

\section{Outcomes at the end of phase two}

An evaluation of the effect of treatment between headgear and functional appliance in children followed by treatment in adolescence revealed no significant difference in final overjet (MD $-0.21 \mathrm{~mm}, 95 \% \mathrm{Cl}-0.57 \mathrm{~mm}$ to $0.15 \mathrm{~mm}, \mathrm{Chi}^{2}=0.01,1 \mathrm{df}, \mathrm{P}$ value $=$ $0.26, \mathrm{I}^{2}=0 \% ; 225$ participants) (Analysis 2.3), final ANB (MD $-0.17^{\circ}$, $95 \% \mathrm{Cl}-0.67^{\circ}$ to $0.34^{\circ}, \mathrm{Chi}^{2}=1.58,1 \mathrm{df}, \mathrm{P}$ value $=0.52, \mathrm{I}^{2}=37 \%$; 222 participants) (Analysis 2.3), PAR score (MD $-0.81,95 \% \mathrm{Cl}-2.21$ to $0.58, \mathrm{Chi}^{2}=0.09,1 \mathrm{df}, \mathrm{P}$ value $=0.25, \mathrm{I}^{2}=0 \% ; 224$ participants) (Analysis 2.3), or the incidence of incisal trauma (OR $0.78,95 \% \mathrm{Cl}$ 0.42 to $1.47, \mathrm{Chi}^{2}=0.08,1 \mathrm{df}, \mathrm{P}$ value $=0.45, \mathrm{I}^{2}=0 \% ; 226$ participants) (Analysis 2.4) (Florida 1998; North Carolina 2004).

\section{Late orthodontic treatment in adolescence (one-phase) for Class II Division 1 malocclusion}

\section{Late orthodontic treatment: functional appliance versus no treatment}

Seven trials compared the use of functional appliances against no treatment. We decided, after considering the clinical and statistical heterogeneity, to analyse the trials according to the type of functional appliance: fixed or removable. Three trials evaluated fixed functional appliances (Alali 2014; Eissa 2017; Elkordy 2016), all of which were assessed as being at unclear risk of bias overall. The other four trials evaluated removable functional appliances and we assessed these trials as being at high risk of bias overall (Cura 1997; Mao 1997; Martina 2013; New Zealand 2000). The overall quality of the evidence was low. 
There was evidence of a reduction in overjet with both removable functional appliances (MD -4.62, 95\% Cl -5.33 to -3.92, P < 0.00001; three trials, 122 participants) and fixed functional appliance (MD $-5.46,95 \% \mathrm{Cl}-6.63$ to $-4.28, \mathrm{P}<0.00001$; two trials, 61 participants) when compared with no treatment (Analysis 3.1).

There was no evidence of a clear difference between use of the fixed appliance and no treatment for final ANB (MD -0.53, 95\% $\mathrm{Cl}-1.27$ to $-0.22, \mathrm{P}=0.17$; three trials, 89 participants) (Analysis 3.2). However, the removable functional appliance reduced ANB significantly compared to no treatment (MD $-2.37^{\circ}, 95 \% \mathrm{Cl}-3.01$ to $-1.74, \mathrm{P}<0.00001$; two trials, 99 participants) (Analysis 3.2).

\section{Late orthodontic treatment: different types of appliances}

Twin Block functional appliance versus other functional appliances

Four trials evaluated overjet (Burhan 2015; Jamilian 2011; London 1998; UK (11-14) 2003). Two of them were at unclear risk of bias (Burhan 2015; Jamilian 2011); and two at high risk of bias (London 1998; UK (11-14) 2003). There was no statistically significant effect of the type of appliance on final overjet (MD $0.08 \mathrm{~mm}, 95 \% \mathrm{Cl}-0.60$ to $0.76, P=0.83 ; 259$ participants) (Analysis 4.1). Six trials evaluated ANB (Baysal 2014; Burhan 2015; Jamilian 2011; Jin 2015; London 1998; UK (11-14) 2003). Three of them were at high risk of bias (Baysal 2014; London 1998; UK (11-14) 2003); and three at unclear risk of bias (Burhan 2015; Jamilian 2011; Jin 2015). There was a statistically significant reduction in ANB with the Twin Block when compared to other functional appliances (MD $-0.56^{\circ}, 95 \% \mathrm{Cl}-0.96$ to $-0.16, \mathrm{P}=0.006 ; 320$ participants) (Analysis 4.1 ).

Twin Block functional appliance versus other modifications of Twin Block appliances

Two trials compared a Twin Block functional appliance versus other modifications of Twin Block appliances; one trial was at high risk of bias and one at low risk of bias (Banks 2004; Yaqoob 2012). There were no statistically significant differences between the Twin Block designs with respect to final overjet (MD $-0.23 \mathrm{~mm}, 95 \% \mathrm{Cl}-0.67$ $\mathrm{mm}$ to $0.22 \mathrm{~mm}, \mathrm{Chi}^{2}=2.59,1 \mathrm{df}, \mathrm{P}$ value $=0.11, \mathrm{I}^{2}=61 \% ; 196$ participants) (Analysis 4.2).

\section{Activator functional appliance versus prefabricated myobrace appliance (PFA)}

The results in this section are based on a single trial at high risk of bias (Cirgić 2016). There was no statistically significant difference between the two groups with respect to final overjet (MD $0.60 \mathrm{~mm}$, $95 \% \mathrm{Cl}-1.63$ to $0.43, \mathrm{P}$ value $=0.25 ; 97$ participants) (Analysis 4.3).

\section{Activator functional appliance versus fixed functional (FORSUS FRD} EZ) appliances

The results in this section are based on one trial (24 participants) at high risk of bias (Bilgiç 2011). Reduction in overjet favoured the FORSUS appliance (MD $2.19 \mathrm{~mm}, 95 \% \mathrm{Cl} 0.58 \mathrm{~mm}$ to $3.80 \mathrm{~mm}, \mathrm{P}$ value $=0.008$ ) (Analysis 4.4); but final ANB favoured the Activator group $\left(\mathrm{MD}-1.74^{\circ}, 95 \% \mathrm{Cl}-3.28^{\circ}\right.$ to $-0.20^{\circ}$, $\mathrm{P}$ value $=0.03$ ) (Analysis 4.4).

Fixed functional (FORSUS FRD) versus fixed functional with mini-implants (FMI)

Two trials, both at unclear risk of bias (Elkordy 2016; Eissa 2017), evaluated this comparison and found no significant difference between the two groups with respect to final overjet (MD - $0.36,95 \%$
$\mathrm{Cl}-1.07$ to 0.35 , $\mathrm{P}$ value $=0.32$; one trial, 29 participants) and final ANB (MD $0.22,95 \% \mathrm{Cl}-0.86$ to $1.30, \mathrm{P}$ value $=0.69$; two trials, 60 participants) (Analysis 4.5).

There was no difference between the groups in patient satisfaction (OR $0.18,95 \% \mathrm{Cl} 0.01$ to $3.97, \mathrm{P}$ value $=0.27$; one trial, 32 participants) (Analysis 4.6).

\section{R-appliance versus anterior inclined bite plate (AIBP)}

A single trial at unclear risk of bias showed no statistically significant difference between the two groups with respect to final ANB (MD $-0.30^{\circ}, 95 \% \mathrm{Cl}-0.99^{\circ}$ to $0.39^{\circ}, \mathrm{P}$ value $=0.40 ; 50$ participants) (Showkatbakhsh 2011) (Analysis 4.7).

\section{Removable functional versus fixed functional}

Three trials at high risk of bias compared orthodontic treatment for adolescents with removable functional appliances to fixed functional appliances (Baysal 2014; Bilgiç 2011; UK (11-14) 2003). There was a statistically significant difference between the groups in overjet ( $\mathrm{MD} 0.74,95 \% \mathrm{Cl} 0.15$ to $1.33, \mathrm{P}=0.01$; two trials, 154 participants) in favour of fixed functional appliances (Analysis 4.8). However, a statistically significant difference in final ANB of $-1.04^{\circ}$ ( $95 \% \mathrm{Cl}-1.60$ to $-0.49, \mathrm{P}=0.0002$; three trials, 185 participants) was found in favour of removable functional appliances (Analysis 4.8).

\section{Fixed functional (FORSUS FRD) versus intermaxillary elastics}

The results in this section are based on one trial at high risk of bias (Aras 2017b). The results showed no statistically significant difference for final overjet (MD $0.28,95 \% \mathrm{Cl}-0.35$ to $0.91, \mathrm{P}=0.39 ; 28$ participants) or final ANB (MD $-0.90,95 \% \mathrm{Cl}-1.96$ to $0.61, \mathrm{P}=0.10$; 28 participants) (Analysis 4.9).

\section{FMA stepwise (SWG) versus FMA single step (SSG)}

The results are based on a single trial at unclear risk of bias (Aras 2017a). There was no statistically significant difference for final overjet ( $\mathrm{MD} 0.23,95 \% \mathrm{Cl}-0.26$ to $0.72, \mathrm{P}=0.36$; 34 participants), but the results favoured stepwise advancement for final ANB value (MD $-0.69,95 \% \mathrm{Cl}-1.19$ to $-0.19, \mathrm{P}=0.007 ; 34$ participants) (Analysis 4.10).

\section{Harvold Activator versus Frankel function regulator}

The results are based on a single trial at high risk of bias (New Zealand 2000). There was a statistically significant difference in the overjet change favouring Harvold Activator when compared with Frankel function regulator (MD $-2.23,95 \% \mathrm{Cl}-5.37$ to $0.49, \mathrm{P}=0.02$; 25 participants) (Analysis 4.11).

\section{DISCUSSION}

\section{Summary of main results}

\section{Early treatment (two-phase) versus late treatment in adolescence (one-phase)}

We have found evidence that orthodontic treatment provided to 7 to 11 year olds with prominent upper front teeth results in a statistically significant reduction in incisor prominence. This effect occurs if the child received treatment with a functional appliance or headgear. This treatment also resulted in some changes in the relationship of the upper and lower jaws. However, while these 
changes or differences at the end of phase one were statistically significant, the quality of evidence for this comparison is low.

When we considered the final outcome of treatment at the end of a second phase of treatment in adolescence, we found that the treatment was effective, in that incisor prominence had been reduced. There were no differences in treatment outcome between the group who had received treatment at a younger age or treatment in adolescence for any variable other than the incidence of new incisal trauma. The results showed a significant reduction in incisor trauma in the early treatment (two-phase) group as compared to the late treatment (one-phase) group. The quality of the evidence for this comparison is low to moderate.

\section{Treatment provided in adolescence (one-phase)}

We found seven studies that measured the effect of treatment with a functional appliance versus an untreated control. Heterogeneity was high, and we analysed fixed and removable appliances separately. We found significant reductions in final overjet with fixed and removable functional appliances (Analysis 3.1). There was evidence for a reduction in final ANB with removable functional appliances. The quality of the evidence was low for both outcomes.

We also found that several studies compared the effect of the Twin Block functional appliance against other functional appliances, for example the Bionator and Herbst appliances. We found that while there was a statistically significant difference in skeletal changes (ANB) in favour of Twin Block. The quality of the evidence was low.

There were three trials that compared orthodontic treatment for adolescents with removable functional appliances to fixed functional appliances. Although a statistically significant reduction in ANB was found in favour of removable functional appliances, and a statistically significant reduction in overjet was found in favour of fixed functional appliances, the changes were so small that they may not be of clinical importance. Additionally, the quality of the evidence was low for both.

\section{Overall completeness and applicability of evidence}

One important finding from this review was that while we identified 27 RCTs, they had been published in 63 different papers. Furthermore, several of the investigators had not only reported outcomes at the end of early treatment, but they had produced several papers that were confined to analysis of subsets of participants, to form interim reports or 'updates'. While they may have had good reasons to follow this publication strategy, in terms of having to compete for the renewal of grant funding, this did result in difficulty interpreting the results of these studies. We approached this problem by identifying the most relevant outcomes and data points and then produced composite data extraction for these studies. We would like to suggest that studies are not reported until they are completed. The registration of trials will go some way to addressing some of these issues, where each trial has a unique identity number that will appear on all publications.

In this review we have analysed data at the end of phase one and phase two in studies that evaluated the effect of early treatment. This is because these trials were carried out to evaluate the effectiveness of early treatment provided when the children were 7 to 11 years old. These studies were then extended to the completion of all orthodontic treatment and included in this review. It could be suggested that we should only report the final findings of these trials. However, we feel that the 'early' treatment studies should be included to illustrate that there were some short-term benefits: for example, reduction in overjet and possible increase in selfesteem. Nevertheless, these findings do not detract from the overall conclusions that early treatment is of limited benefit.

Finally, there was great variation in the outcome measures that were adopted by the investigators. This was particularly marked with the use of cephalometric analyses and is not surprising when we consider that there are many different types of analysis. We would suggest that uniformly applied cephalometric analyses are used when future studies are planned, so that adequate comparisons between trials can be achieved.

\section{Quality of the evidence}

We found 27 RCTs evaluating orthodontic treatment of people with prominent upper front teeth (Class II malocclusion). The overall quality of evidence in this review was low (Summary of findings for the main comparison; Summary of findings 2; Summary of findings 3; Summary of findings 4; Summary of findings 5), with only two trials assessed as being at low risk of bias (UK (Mixed) 2009; Yaqoob 2012). There were three two-phase studies that contributed data to this review (Florida 1998; North Carolina 2004; UK (Mixed) 2009). It is important to mention that carrying out a trial of a twophase study (treatment for young children followed by treatment in adolescence) is much more difficult and potentially more prone to bias than a one-phase study. However, in this review, the two-phase studies were of better quality than most of the one-phase studies.

It is important to point out that one study did not report a complete data set. Although six different articles were published, none of them included a complete data set and did not give reasons for not doing so (Ghafari 1998).

It is interesting to note that one study was prematurely stopped due to harms (Thiruvenkatachari 2010). The study compared the Twin Block and the Dynamax appliances and showed a statistically significant overjet reduction in the Twin Block group at the end of the first interim analysis. The study also reported significantly greater incidence of harms with the Dynamax appliance.

\section{Potential biases in the review process}

A potential bias could be reporting bias. We avoided this by carrying out a broad search with no restrictions on language or publication status.

Another potential bias in the review could be our categorisation based on terminology of 'early' and 'late' treatment. In the protocol, we defined early treatment as treatment initiated between 7 and 11 years of age and late treatment as treatment initiated between 12 and 16 years of age. Some studies were difficult to categorise as they had recruited participants between 9 and 12 years of age (see Characteristics of included studies section). As the 'early' and 'late' terminologies are accepted globally, we considered twophase studies as early treatment and one-phase studies as late treatment.

\section{Agreements and disagreements with other studies or reviews}

There are several systematic reviews that have been performed on the effects of functional appliances for patients with increased 
overjet (Antonarakis 2007; Barnett 2008; Cozza 2006; Flores-Mir 2007; Perillo 2012; Ehsani 2015; Koretsi 2015; Zymperdikas 2016; Yang 2016; Pacha 2016). Antonarakis 2007 reported that functional appliances show a statistically significant reduction in overjet and ANB value when compared with untreated controls. However, the authors have included prospective and retrospective studies and did not separate early and late treatment. This makes it difficult to compare with the present review. Similarly, Barnett 2008, Cozza 2006, Flores-Mir 2007, Perillo 2012, Ehsani 2015, Koretsi 2015, Zymperdikas 2016, Yang 2016, and Pacha 2016 included nonrandomised studies. Cozza 2006 evaluated the effects of functional appliances on mandibular length and did not report on other dental measurements. Barnett 2008, Flores-Mir 2007 and Yang 2016 were confined to the Herbst appliance, whereas Perillo 2012 evaluated the Frankel appliance and Ehsani 2015 studied Twin-Block. Koretsi 2015 compared removable functional appliances versus untreated Class II; Zymperdikas 2016 compared fixed functional appliances versus untreated Class II; and Pacha 2016 compared fixed versus removable functional appliances. This makes it impossible to compare the results with the present review.

\section{AUTHORS' CONCLUSIONS}

\section{Implications for practice}

Orthodontic treatment for children, followed by a later phase of treatment when in adolescence, may significantly reduce the incidence of incisal trauma as compared to treatment that is provided in one phase in adolescence. There seem to be no other advantages for providing a two-phase treatment in children compared to one-phase in adolescence.

Orthodontic treatment with functional appliances in adolescents with prominent upper front teeth appears to significantly reduce the protrusion of the upper teeth when compared to adolescents who are not treated.

\section{Implications for research}

Consideration needs to be given to forming a consensus on the type of outcome measures that are used in orthodontic trials; this is particularly relevant for cephalometric measurement and analysis. In addition, studies should be carried out at the same time points and reported according to the Consolidated Standards of Reporting Trials (CONSORT) guidelines. Moreover, intention-to-treat analysis should be carried out properly, since attrition bias was the most common risk of bias in this review: it was considered 'high risk' in 8 of the 27 studies.

\section{ACK N O WLEDGEMENTS}

Current update (2017): our thanks to Osama Alali (University of Damascus), Ahmad Burhan (Al-Baath University), Sherif Elkordy (Cairo University) and Emina Čirgić (University of Gothenburg) for providing additional data for this review. We would like to thank Janet Lear (Cochrane Oral Health) for her help to find some papers and Professors Chengge Hua, Chunjie Li and Huimin Hu for their translation support from Chinese. We thank Laura MacDonald, Anne Littlewood, Dr Fang Hua, Professor Anne-Marie Glenny and Professor Helen Worthington of Cochrane Oral Health, copy editor Jason Elliot-Smith, and external referees Professor Ross Hobson and Dr Philipe Amat.

Previous versions: we are very grateful to Helen Worthington for her work on previous versions of this review. Thanks to Anne Littlewood (Cochrane Oral Health) for her help in conducting the searches, and to Luisa Fernandez Mauleffinch (Cochrane Oral Health) for editorial management of the review. Thanks to Bill Shaw for his initial advice; Bill Proffit, Kitty Tulloch (University of North Carolina), Tim Wheeler, Sue McGorry (University of Florida), David Morris, Danny Op Heij and Urban Hagg for providing additional data for this review; John Scholey for undertaking some of the handsearching and Sue Pender for retrieving, copying and collating the full papers. We would also like to thank Susan Furness (Cochrane Oral Health) and all those who have provided comments and editorial input. 


\section{R E F E R E N C E S}

\section{References to studies included in this review}

\section{Alali 2014 \{published data only\}}

Alali $\mathrm{OH}$. A prospective controlled evaluation of Class II division 1 malocclusions treated with fixed lingual mandibular growth modificator. Angle Orthodontist 2014;84(3):527-33.

\section{Aras 2017a \{published data only\}}

Aras I, Pasaoglu A, Olmez S, Unal I, Aras A. Upper airway changes following single-step or stepwise advancement using the Functional Mandibular Advancer. Journal of Orofacial Orthopedics 2016;77(6):454-62

* Aras I, Pasaoglu A, Olmez S, Unal I, Tuncer AV, Aras A. Comparison of stepwise vs single-step advancement with the Functional Mandibular Advancer in Class II division 1 treatment. Angle Orthodontist 2017;87(1):82-7.

\section{Aras 2017b \{published data only\}}

Aras I, Pasaoglu A. Class II subdivision treatment with the Forsus Fatigue Resistant Device vs intermaxillary elastics. Angle Orthodontist 2017;87:371-6.

\section{Banks 2004 \{published data only\}}

Banks P, Wright J, O'Brien K. Incremental versus maximum bite advancement during twin-block therapy: a randomized controlled clinical trial. American Journal of Orthodontics and Dentofacial Orthopedics 2004;126(5):583-8.

\section{Baysal 2014 \{published data only\}}

* Baysal A, Uysal T. Dentoskeletal effects of Twin Block and Herbst appliances in patients with Class II division 1 mandibular retrognathy. European Journal of Orthodontics 2014;36(2):164-72

Baysal A, Uysal T. Soft tissue effects of Twin Block and Herbst appliances inpatients with Class II division 1 mandibular retrognathy. European Journal of Orthodontics 2013;35:71-81.

Bilgiç 2011 \{published data only\}

Bilgiç F, Hamamci O, Başaran G. Comparison of the effects of fixed and removable functional appliances on the skeletal and dentoalveolar structures. Australian Orthodontic Journal 2011;27(2):110-6.

\section{Burhan 2015 \{published data only\}}

Burhan AS, Nawaya FR. Dentoskeletal effects of the BiteJumping Appliance and the Twin-Block Appliance in the treatment of skeletal Class II malocclusion: a randomized controlled trial. European Journal of Orthodontics 2015;37(3):330-7.

\section{Cevidanes 2003 \{published data only\}}

Cevidanes LH, Franco AA, Scanavini MA, Vigorito JW, Enlow DH, Proffit WR. Clinical outcomes of Frankel appliance therapy assessed with a counterpart analysis. American Journal of Orthodontics and Dentofacial Orthopedics 2003;123(4):379-87.

\section{Cirgić 2016 \{published data only\}}

Čirgić E, Kjellberg H, Hansen K. Discomfort, expectations, and experiences during treatment of large overjet with Andresen Activator or Prefabricated Functional Appliance: a questionnaire survey. Acta Orthopaedica Scandinavica 2017;75(3):166-72.

* Čirgić E, Kjellberg H, Hansen K. Treatment of large overjet in Angle Class II: division 1 malocclusion with Andresen activators versus prefabricated functional appliances - a multicenter, randomized, controlled trial. European Journal of Orthodontics 2016;38(5):516-24.

\section{Cura 1997 \{published data only\}}

Cura N, Sarac M. The effect of treatment with the Bass appliance on skeletal Class II malocclusions: a cephalometric investigation. European Journal of Orthodontics 1997;19(6):691-702.

\section{Eissa 2017 \{published and unpublished data\}}

Eissa O, El-Shennawy M, Gaballah S, El-Meehy G, El Bialy T. Treatment outcomes of Class II malocclusion cases treated with miniscrew-anchored Forsus Fatigue Resistant Device: a randomized controlled trial. Angle Orthodontist 2017;87(6):824-33.

\section{Elkordy 2016 \{published data only\}}

Elkordy SA, Abouelezz AM, Fayed MMS, Attia KH, Ishaq RAR, Mostafa YA. Three-dimensional effects of the mini-implantanchored Forsus Fatigue Resistant Device: A randomized controlled trial. Angle Orthodontist 2016;86(2):292-305.

Elkordy SA, Fayed MMS, Abouelezz AM, Attia KH. Comparison of patient acceptance of the Forsus Fatigue Resistant Device with and without mini-implant anchorage: A randomized controlled trial. American Journal of Orthodontics and Dentofacial Orthopedics 2015;148(5):755-64.

\section{Florida 1998 \{published and unpublished data\}}

Chen DR, McGorray SP, Dolce C, Wheeler TT. Effect of early Class II treatment on the incidence of incisor trauma. American Journal of Orthodontics and Dentofacial Orthopedics 2011;140(4):e155-60.

Dolce C, McGorray SP, Brazeau L, King GJ, Wheeler TT. Timing of Class II treatment: skeletal changes comparing 1-phase and 2-phase treatment. American Journal of Orthodontics and Dentofacial Orthopedics 2007; Vol. 132, issue 4:481-9.

Johnson PD, Cohen DA, Aiosa L, McGorray S, Wheeler T. Attitudes and compliance of pre-adolescent children during early treatment of Class II malocclusion. Clinical Orthodontics and Research 1998;1(1):20-8.

Keeling SD, Garvan CW, King GJ, Wheeler TT, McGorray S. Temporomandibular disorders after early Class II treatment with bionators and headgears: results from a randomized controlled trial. Seminars in Orthodontics 1995;1(3):149-64.

${ }^{*}$ Keeling SD, Wheeler TT, King GJ, Garvan CW, Cohen DA, Cabassa S, et al. Anteroposterior skeletal and dental changes 
after early Class II treatment with bionators and headgear. American Journal of Orthodontics and Dentofacial Orthopedics 1998;113(1):40-50.

King GJ, McGorray SP, Wheeler TT, Dolce C, Taylor M. Comparison of peer assessment ratings (PAR) from 1-phase and 2-phase treatment protocols for Class II malocclusions. American Journal of Orthodontics and Dentofacial Orthopedics 2003;123(5):489-96.

King GJ, Wheeler TT, McGorray SP. Randomised prospective clinical trial evaluating early treatment of Class II malocclusions. European Journal of Orthodontics 1999;21(4):445.

Wheeler TT, McGorray SP, Dolce C, Taylor MG, King GJ. Effectiveness of early treatment of Class II malocclusion. American Journal of Orthodontics and Dentofacial Orthopedics 2002;121(1):9-17.

Wortham JR, McGorray S, Taylor M, Dolce C, King DJ, Wheeler TT. Arch dimension changes following phase I and phase II orthodontic class II treatment. Journal of Dental Research 2001;80(Spec Issue (AADR Abstracts)):177 (Abs No 1131).

\section{Ghafari 1998 \{published data only\}}

Ghafari J. Class II malocclusion: Comparison of alternative treatments and time of treatment. European Journal of Orthodontics 1999;21(4):439-40.

Ghafari J, Efstratiadis S, Shofer FS, Markowitz D, JacobssonHunt U, Baumrind S, et al. Relation between occlusal and cephalometric changes in the treatment of distocclusion. Journal of Dental Research 1999;78(March Spec Issue):443 (Abs No 2699).

Ghafari J, Jacobsson-Hunt U, Markowitz DL, Shofer FS, Laster LL. Changes of arch width in the early treatment of Class II, division 1 malocclusions. American Journal of Orthodontics and Dentofacial Orthopedics 1994;106(5):496-502.

Ghafari J, King GJ, Tulloch JF. Early treatment of Class II, division 1 malocclusion--comparison of alternative treatment modalities. Clinical Orthodontics and Research 1998;1(2):107-17.

* Ghafari J, Shofer FS, Jacobsson-Hunt U, Markowitz DL, Laster LL. Headgear versus function regulator in the early treatment of Class II, division 1 malocclusion: a randomized clinical trial. American Journal of Orthodontics and Dentofacial Orthopedics 1998;113(1):51-61.

Ghafari JG, Shofer FS, Laster LL, Markowitz DL, Silverton S, Katz SH. Monitoring growth during orthodontic treatment. Seminars in Orthodontics 1995;1(3):165-75.

\section{Jamilian 2011 \{published and unpublished data\}}

Jamilian A, Showkatbakhsh R, Amiri SS. Treatment effects of the R-appliance and twin block in Class II division 1 malocclusion. European Journal of Orthodontics 2011;33(4):354-8.
Jin 2015 \{published data only\}

Jin Z, Liu W. Biomechanical difference between Twin-Block appliance and straight wire appliance in the early treatment of Class II division 1 malocclusion. Chinese Journal of Tissue Engineering Research 2015;19(12):1842-5.

Lee 2007 \{published data only\}

Lee RT, Kyi CS, Mack GJ. A controlled clinical trial of the effects of the Twin Block and Dynamax appliances on the hard and soft tissues. European Journal of Orthodontics 2007;29(3):272-82.

London 1998 \{published data only\}

* Illing HM, Morris DO, Lee RT. A prospective evaluation of Bass, Bionator and Twin Block appliances. Part I--The hard tissues. European Journal of Orthodontics 1998;20(5):501-16.

McDonagh S, Moss JP, Goodwin P, Lee RT. A prospective optical surface scanning and cephalometric assessment of the effect of functional appliances on the soft tissues. European Journal of Orthodontics 2001;23(2):115-26.

Morris DO, Illing HM, Lee RT. A prospective evaluation of Bass, Bionator and Twin Block appliances. Part II--The soft tissues. European Journal of Orthodontics 1998;20(6):663-84.

Mao 1997 \{published data only\}

Mao J, Zhao H. The correction of Class II, division 1 malocclusion with bionator headgear combination appliance. Journal of Tongji Medical University 1997;17(4):254-6.

Martina 2013 \{published data only\}

* Martina R, Cioffi I, Galeotti A, Tagliaferri R, Cimino R, Michelotti A, et al. Efficacy of the Sander bite-jumping appliance in growing patients with mandibular retrusion: a randomized controlled trial. Orthodontics \& Craniofacial Research 2013;16(2):116-26.

\section{New Zealand 2000 \{published data only\}}

Courtney M, Harkness M, Herbison P. Maxillary and cranial base changes during treatment with functional appliances. American Journal of Orthodontics and Dentofacial Orthopedics 1996;109(6):616-24.

Nelson C, Harkness M, Herbison P. Mandibular changes during functional appliance treatment. American Journal of Orthodontics and Dentofacial Orthopedics 1993;104(2):153-61.

O'Neill K, Harkness M, Knight R. Ratings of profile attractiveness after functional appliance treatment. American Journal of Orthodontics and Dentofacial Orthopedics 2000;118(4):371-6.

Webster T, Harkness M, Herbison P. Associations between changes in selected facial dimensions and the outcome of orthodontic treatment. American Journal of Orthodontics and Dentofacial Orthopedics 1996;110(1):46-53.

* Wijayaratne D, Harkness M, Herbison P. Functional appliance treatment assessed using the PAR index. Australian Orthodontic Journal 2000;16(3):118-26. 
North Carolina 2004 \{published data only\}

Almeida MA, Phillips C, Kula K, Tulloch C. Stability of the palatal rugae as landmarks for analysis of dental casts. Angle Orthodontist 1995;65(1):43-8.

Brin I, Tulloch JF, Koroluk L, Philips C. External apical root resorption in Class II malocclusion: a retrospective review of 1versus 2-phase treatment. American Journal of Orthodontics and Dentofacial Orthopedics 2003;124(2):151-6.

Dann C 4th, Phillips C, Broder HL, Tulloch JF. Self-concept, Class II malocclusion, and early treatment. Angle Orthodontist 1995;65(6):411-6.

Ehmer U, Tulloch CJ, Proffit WR, Phillips C. An international comparison of early treatment of angle Class-II/1 cases. Skeletal effects of the first phase of a prospective clinical trial. Journal of Orofacial Orthopedics 1999;60(6):392-408.

Koroluk LD, Tulloch JF, Phillips C. Incisor trauma and early treatment for Class II Division 1 malocclusion. American Journal of Orthodontics and Dentofacial Orthopedics 2003;123(2):117-26.

Proffit WR, Tulloch JF. Preadolescent Class II problems: treat now or wait?. American Journal of Orthodontics and Dentofacial Orthopedics 2002;121(6):560-2.

Tulloch JF. Early versus late treatment for Class II malocclusions. European Journal of Orthodontics 1999;21(4):453.

Tulloch JF, Phillips C, Koch G, Proffit WR. The effect of early intervention on skeletal pattern in Class II malocclusion: a randomized clinical trial. American Journal of Orthodontics and Dentofacial Orthopedics 1997;111(4):391-400.

Tulloch JF, Phillips C, Proffit WR. Benefit of early Class II treatment: progress report of a two-phase randomized clinical trial. American Journal of Orthodontics and Dentofacial Orthopedics 1998;113(1):62-72.

Tulloch JF, Proffit WR, Phillips C. Influences on the outcome of early treatment for Class II malocclusion. American Journal of Orthodontics and Dentofacial Orthopedics 1997;111(5):533-42.

* Tulloch JF, Proffit WR, Phillips C. Outcomes in a 2-phase randomized clinical trial of early Class II treatment. American Journal of Orthodontics and Dentofacial Orthopedics 2004;125(6):657-67.

Tulloch JF, Rogers L, Phillips C. Early results from a randomized clinical trial of growth modification in Class II malocclusion. Journal of Dental Research 1992;72(Spec Issue (IADR Abstracts)):523.

Showkatbakhsh 2011 \{published and unpublished data\} Showkatbakhsh R, Meybodi SE, Jamilian A, Meybodi SA, Meybodi EM. Treatment effects of R-appliance and anterior inclined bite plate in class II, division I malocclusion. Journal of Applied Oral Science : Revista FOB 2011;19(6):634-8.

\section{Thiruvenkatachari 2010 \{published data only\}}

Thiruvenkatachari B, Sandler J, Murray A, Walsh T, O'Brien K. Comparison of Twin-block and Dynamax appliances for the treatment of Class II malocclusion in adolescents: a randomized controlled trial. American Journal of Orthodontics and Dentofacial Orthopedics 2010;138(2):144.e1-9; discussion 144-5.

\section{UK (11-14) 2003 \{published and unpublished data\}}

O'Brien K, Wright J, Conboy F, Sanjie Y, Mandall N, Chadwick S, et al. Effectiveness of treatment for Class II malocclusion with the Herbst or twin-block appliances: a randomized, controlled trial. American Journal of Orthodontics and Dentofacial Orthopedics 2003;124(2):128-37.

UK (Mixed) 2009 \{published and unpublished data\}

O'Brien K, Wright J, Conboy F, Appelbe P, Davies L, Connolly I, et al. Early treatment for Class II Division 1 malocclusion with the Twin-block appliance: a multi-center, randomized, controlled trial. American Journal of Orthodontics and Dentofacial Orthopedics 2009;135(5):573-9.

O'Brien K, Wright J, Conboy F, Chadwick S, Connolly I, Cook P, et al. Effectiveness of early orthodontic treatment with the Twinblock appliance: a multicenter, randomized, controlled trial. Part 2: Psychosocial effects. American Journal of Orthodontics and Dentofacial Orthopedics 2003;124(5):488-94.

* O'Brien K, Wright J, Conboy F, Sanjie Y, Mandall N, Chadwick S, et al. Effectiveness of early orthodontic treatment with the Twin-block appliance: a multicenter, randomized, controlled trial. Part 1: Dental and skeletal effects. American Journal of Orthodontics and Dentofacial Orthopedics 2003;124(3):234-43.

Yaqoob 2012 \{published data only\}

Yaqoob O, Dibiase AT, Cobourne MT. Use of the Clark twin block with and without a labial bow in the correction of class II division 1 malocclusion: a randomized clinical trial. Journal of Orthodontics 2010;37(4):310.

* Yaqoob O, Dibiase AT, Fleming PS, Cobourne MT. Use of the Clark Twin Block functional appliance with and without an upper labial bow: a randomized controlled trial. Angle Orthodontist 2012;82(2):363-9.

\section{References to studies excluded from this review}

Aknin 2000 \{published data only\}

Aknin JJ, Morra L. Comparative study of mandibular growth and rotation in two sample groups treated according to the "Distal Active Concept" or the Edgewise technique. Orthodontie Francaise 2000;71(4):343-61.

Aksakalli 2016 \{published data only\}

Aksakalli S, Calik B, Kara B, Ezirganli S. Accelerated tooth movement with piezocision and its periodontal transversal effects in patients with Class II malocclusion. Angle Orthodontist 2016;86:59-65.

\section{Al-Sibaie 2014 \{published data only\}}

Al-Sibaie S, Hajeer MY. Assessment of changes following enmasse retraction with mini-implants anchorage compared to two-step retraction with conventional anchorage in patients 
with class II division 1 malocclusion: a randomized controlled trial. European Journal of Orthodontics 2014;36(3):275-83.

Antonarakis 2015 \{published data only\}

Antonarakis GS, Kiliaridis S. Predictive value of masseter muscle thickness and bite force on Class II functional appliance treatment: a prospective controlled study. European Journal of Orthodontics 2015;37(6):570-7.

\section{Antunes 2013 \{published data only\}}

Antunes CF, Bigliazzi R, Bertoz FA, Ortolani CL, Franchi L, Faltin K. Morphometric analysis of treatment effects of the Balters bionator in growing Class II patients. Angle Orthodontist 2013;83(3):455-9.

\section{Ashmore 2002 \{published data only\}}

Ashmore JL, Kurland BF, King GJ, Wheeler TT, Ghafari J, Ramsay DS. A 3-dimensional analysis of molar movement during headgear treatment. American Journal of Orthodontics and Dentofacial Orthopedics 2002;121(1):18-30.

\section{Aslan 2014 \{published data only\}}

Aslan BI, Kucukkaraca E, Turkoz C, Dincer M. Treatment effects of the Forsus Fatigue Resistant Device used with miniscrew anchorage. Angle Orthodontist 2014;84(1):76-87.

\section{Baccetti 2009 \{published data only\}}

Baccetti T, Franchi L, Kim LH. Effect of timing on the outcomes of 1-phase nonextraction therapy of Class II malocclusion. American Journal of Orthodontics and Dentofacial Orthopedics 2009;136(4):501-9.

\section{Bailleau 2012 \{published data only\}}

Bailleau A, Aknin JJ, Gebeile-Chauty S. One phase or twophase orthodontic treatment: comparisons [Traitements orthodontiques en une ou deux phases : comparaisons]. Orthodontie Francaise 2012;83(4):289-96.

\section{Bishara 1995 \{published data only\}}

Bishara SE, Cummins DM, Jakobsen JR, Zaher AR. Dentofacial and soft tissue changes in Class II, division 1 cases treated with and without extractions. American Journal of Orthodontics and Dentofacial Orthopedics 1995;107(1):28-37.

\section{Booij 2013 \{published data only\}}

Booij J W, Goeke J, Bronkhorst E M, Katsaros C, Ruf S. Class II treatment by extraction of maxillary first molars or Herbst appliance: dentoskeletal and soft tissue effects in comparison. Journal of Orofacial Orthopedics 2013;74(1):52-63.

\section{Bremen 2015 \{published data only\}}

Bremen J, Ludwig B, Ruf S. Anchorage loss due to Herbst mechanics-preventable through miniscrews?. European Journal of Orthodontics 2015;37(5):462-6.

\section{Burhan 2013 \{published data only\}}

Burhan A S. Combined treatment with headgear and the Frog appliance for maxillary molar distalization: a randomized controlled trial. Korean Journal of Orthodontics 2013;43(2):101-9.

\section{Chavan 2014 \{published data only\}}

Chavan SJ, Bhad WA, Doshi UH. Comparison of temporomandibular joint changes in Twin Block and Bionator appliance therapy: a magnetic resonance imaging study. Progress in Orthodontics 2014;15:57.

Chen 2013 \{published data only\}

Chen XH, Hua YM, Xie XQ, Yu XJ, Wang J, Liu LM. Clinical study of extraction treatment of Class II division I malocclusion with Empower self-ligating brackets. Shanghai Kou Qiang Yi Xue 2013;22(3):316-21.

\section{Chen 2015 \{published data only\}}

Chen H, Yagi K, Almeida FR, Pliska BT, Lowe AA. A pilot study on the dentoalveolar and skeletal effects of two functional appliances in Class II, Division 1 growing children. International Journal of Orthodontics (Milwaukee, Wis.) 2015;26(2):15-20.

\section{Chintakanon 2000 \{published data only\}}

Chintakanon K, Sampson W, Wilkinson T, Townsend G. A prospective study of Twin-block appliance therapy assessed by magnetic resonance imaging. American Journal of Orthodontics and Dentofacial Orthopedics 2000;118(5):494-504.

\section{Chiqueto 2013 \{published data only\}}

Chiqueto K, Henriques JF, Barros SE, Janson G. Angle Class II correction with MARA appliance. Dental Press Journal of Orthodontics 2013;18(1):35-44.

\section{Collett 2000 \{published data only\}}

Collett AR. Current concepts on functional appliances and mandibular growth stimulation. Australian Dental Journal 2000;45(3):173-8.

\section{Cura 1996 \{published data only\}}

Cura N, Sarac M, Ozturk Y, Surmeli N. Orthodontic and orthopedic effects of Activator, Activator-HG combination, and Bass appliances: a comparative study. American Journal of Orthodontics and Dentofacial Orthopedics 1996;110(1):36-45.

Dahan 1989 \{published data only\}

Dahan J, Serhal JB, Englebert A. Cephalometric changes in Class II, Division 1 cases after orthopedic treatment with the bioactivator. American Journal of Orthodontics and Dentofacial Orthopedics 1989;95(2):127-37.

\section{Davoody 2011 \{published data only\}}

Davoody AR, Upadhyay M, Uribe F, Nanda R. Anchorage control comparison between differential moments and mini-screws. Proceedings of the 89th General Session of the International Association for Dental Research. IADR, 2011.

\section{De Almeida 2002 \{published data only\}}

De Almeida MR, Henriques JF, Ursi W. Comparative study of the Frankel (FR-2) and bionator appliances in the treatment of Class II malocclusion. American Journal of Orthodontics and Dentofacial Orthopedics 2002;121(5):458-66.

DeVincenzo 1989 \{published data only\}

DeVincenzo JP, Winn MW. Orthopedic and orthodontic effects resulting from the use of a functional appliance with 
different amounts of protrusive activation. American Journal of Orthodontics and Dentofacial Orthopedics 1989;96(3):181-90.

dos Santos-Pinto 2013 \{published data only\}

dos Santos-Pinto PR, Martins L P, dos Santos-Pinto A, Gandini Junior LG, Raveli D B, dos Santos-Pinto CC. Mandibular growth and dentoalveolar development in the treatment of class II, division 1, malocclusion using Balters Bionator according to the skeletal maturation. Dental Press Journal of Orthodontics 2013;18(4):43-52.

\section{Du 2002 \{published data only\}}

Du X, Hagg U, Rabie AB. Effects of headgear Herbst and mandibular step-by-step advancement versus conventional Herbst appliance and maximal jumping of the mandible. European Journal of Orthodontics 2002;24(2):167-74.

\section{El-Dawlatly 2014 \{published data only\}}

El-Dawlatly MM, Abou-El-Ezz AM, El-Sharaby FA, Mostafa YA. Zygomatic mini-implant for Class II correction in growing patients. Journal of Orofacial Orthopedics 2014;75(3):213-25.

Erbas 2014 \{published data only\}

Erbas B, Kocadereli I. Upper airway changes after Xbow appliance therapy evaluated with cone beam computed tomography. Angle Orthodontist 2014;84(4):693-700.

\section{Erverdi 1995 \{published data only\}}

Erverdi N, Ozkan G. A cephalometric investigation of the effects of the Elastic Bite-block in the treatment of Class II division 1 malocclusions. European Journal of Orthodontics 1995;17(5):375-84.

\section{Falck 1989 \{published data only\}}

Falck F, Frankel R. Clinical relevance of step-by-step mandibular advancement in the treatment of mandibular retrusion using the Frankel appliance. American Journal of Orthodontics and Dentofacial Orthopedics 1989;96(4):333-41.

\section{Fang 2006 \{published data only\}}

Fang G, Xu JY, Luo Y. Use of PAR index to evaluate the treatment outcome for Class II division 1 malocclusion with different tooth extraction patterns. Shanghai Kou Qiang Yi Xue [Shanghai Journal of Stomatology] 2006;15(1):31-3.

\section{Fernandes 2010 \{published data only\}}

Fernandes ÁF, Brunharo I H, Quintão CC, Costa MG, De OliveiraCosta M R. Effectiveness of twin blocks and extraoral maxillary splint (Thurow) appliances for the correction of Class II relationships. World Journal of Orthodontics 2010;11(3):230-5.

\section{Firouz 1992 \{published data only\}}

Firouz M, Zernik J, Nanda R. Dental and orthopedic effects of high-pull headgear in treatment of Class II, division 1 malocclusion. American Journal of Orthodontics and Dentofacial Orthopedics 1992;102(3):197-205.

\section{Franchi 2013 \{published data only\}}

Franchi L, Pavoni C, Faltin K, McNamara JA, Cozza P. Long-term skeletal and dental effects and treatment timing for functional appliances in Class II malocclusion. Angle Orthodontist 2013;83(2):334-40.

Franco 2002 \{published data only\}

Franco AA, Yamashita HK, Lederman HM, Cevidanes LH, Proffit WR, Vigorito JW. Frankel appliance therapy and the temporomandibular disc: a prospective magnetic resonance imaging study. American Journal of Orthodontics and Dentofacial Orthopedics 2002;121(5):447-57.

Freeman 2009 \{published data only\}

Freeman DC, McNamara JA Jr, Baccetti T, Franchi L, Frankel C. Long-term treatment effects of the FR-2 appliance of Frankel. American Journal of Orthodontics and Dentofacial Orthopedics 2009;135(5):570.e1-6; discussion 570-1.

Ghafari 2012 \{published data only\}

Ghafari JG, Efstratiadis S, Kassab A, Saadeh ME. Dominance of specific facial components in predicting Class II outcome. Proceedings of the General Session of the International Association of Dental Research. IADR, 2012.

\section{Ghiglione 2000 \{published data only\}}

Ghiglione V, Maspero C, Garagiola U. Skeletal Class II therapy Effects of Bionator and Teuscher appliances. European Journal of Orthodontics 2000;22(4):445.

\section{Gianelly 1983 \{published data only\}}

Gianelly AA, Brosnan P, Martignoni M, Bernstein L. Mandibular growth, condyle position and Frankel appliance therapy. Angle Orthodontist 1983;53(2):131-42.

\section{Gong 2014 \{published data only\}}

Gong Y, Yu Q, Li PL, Wang HH, Wei B, Shen G. Efficacy evaluation of fixed Twin-block appliance and tooth extraction in skeletal Class II malocclusion. Shanghai Kou Qiang Yi Xue [Shanghai Journal of Stomatology] 2014;23(5):597-600.

\section{Gong 2015 \{published data only\}}

Gong Y, Li PL, Wang HH, Yu Q, Wei B, Shen G. Soft tissue linear evaluation of fixed Twin-block appliance treatment and tooth extraction in skeletal Class II malocclusion. Shanghai Kou Qiang Yi Xue [Shanghai Journal of Stomatology] 2015;24(2):232-5.

\section{Guner 2003 \{published data only\}}

Guner DD, Ozturk Y, Sayman HB. Evaluation of the effects of functional orthopaedic treatment on temporomandibular joints with single-photon emission computerized tomography. European Journal of Orthodontics 2003;25(1):9-12.

Hagg 2002 \{published data only\}

Hagg U, Tse EL, Rabie AB, Robinson W. A comparison of splinted and banded Herbst appliances: treatment changes and complications. Australian Orthodontic Journal 2002;18(2):76-81.

\section{Haj-Younis 2016 \{published data only\}}

Haj-Younis S, Khattab TZ, Hajeer MY, Farah H. A comparison between two lingual orthodontic brackets in terms of speech performance and patients' acceptance in correcting Class II, Division 1 malocclusion: a randomized controlled trial. Dental Press Journal of Orthodontics 2016;21(4):80-8. 
Harvold 1971 \{published data only\}

Harvold EP, Vargervik K. Morphogenetic response to activator treatment. American Journal of Orthodontics 1971;60(5):478-90.

\section{Hemmatpour 2017 \{published data only\}}

Hemmatpour S, Mokhtar A, Rakhshan V. Effects of Sabbagh Universal Spring 2 fixed functional appliance on class II/1 patients at their postpubertal-peak growth period compared with the extraction method: a randomized clinical trial. Journal of Orofacial Orthopedics 2017;1:41-51.

\section{Hiyama 2002 \{published data only\}}

Hiyama S, Kuribayashi G, Ono T, Ishiwata Y, Kuroda T. Nocturnal masseter and suprahyoid muscle activity induced by wearing a bionator. Angle Orthodontist 2002;72(1):48-54.

\section{Ingervall 1991 \{published data only\}}

Ingervall $\mathrm{B}$, Thuer $\mathrm{U}$. Temporal muscle activity during the first year of Class II, division 1 malocclusion treatment with an activator. American Journal of Orthodontics and Dentofacial Orthopedics 1991;99(4):361-8.

\section{Iscan 1997 \{published data only\}}

Iscan HN, Sarisoy L. Comparison of the effects of passive posterior bite-blocks with different construction bites on the craniofacial and dentoalveolar structures. American Journal of Orthodontics and Dentofacial Orthopedics 1997;112(2):171-8.

\section{Janson 2003 \{published data only\}}

Janson GR, Toruno JL, Martins DR, Henriques JF, de Freitas MR. Class II treatment effects of the Frankel appliance. European Journal of Orthodontics 2003;25(3):301-9.

\section{Jarrell 2001 \{published data only\}}

Jarrell KT, Hudson JM, Killiany DM. Activator-headgear combination appliance treatment of Class II, division I malocclusion. Journal of Dental Research 2001;80 Special Issue:180 (Abs No 1156).

\section{Jena 2013 \{published data only\}}

Jena AK, Singh SP, Utreja AK. Effectiveness of twin-block and Mandibular Protraction Appliance-IV in the improvement of pharyngeal airway passage dimensions in Class II malocclusion subjects with a retrognathic mandible. Angle Orthodontist 2013;83(4):728-34

\section{Johansson 2012 \{published data only\}}

Johansson K, Lundström F. Orthodontic treatment efficiency with self-ligating and conventional edgewise twin brackets: a prospective randomized clinical trial. Angle Orthodontist 2012;82(5):929-34

\section{Kalra 1989 \{published data only\}}

Kalra V, Burstone CJ, Nanda R. Effects of a fixed magnetic appliance on the dentofacial complex. American Journal of Orthodontics and Dentofacial Orthopedics: 1989;95(6):467-78.

\section{Kaya 2013 \{published data only\}}

Kaya B, Sar C, Arman-Özçirpici A, Polat-Özsoy O. Palatal implant versus zygoma plate anchorage for distalization of maxillary posterior teeth. European Journal of Orthodontics 2013;35(4):507-14.

Keski-Nisula 2003 \{published data only\}

Keski-Nisula K, Lehto R, Lusa V, Keski-Nisula L, Varrela J. Occurrence of malocclusion and need of orthodontic treatment in early mixed dentition. American Journal of Orthodontics and Dentofacial Orthopedics 2003;124(6):631-8.

\section{Kumar 1996 \{published data only\}}

Kumar S, Sidhu SS, Kharbanda OP. A cephalometric evaluation of the dental and facial-skeletal effects using the Bionator with stepwise protrusive activations. Journal of Clinical Pediatric Dentistry 1996;20(2):101-8.

\section{Landazuri 2013 \{published data only\}}

Landazuri DR, Raveli DB, dos Santos-Pinto A, Dib LP, Maia S. Changes on facial profile in the mixed dentition, from natural growth and induced by Balters' bionator appliance. Dental Press Journal of Orthodontics 2013;18(2):108-15.

\section{Lange 1995 \{published data only\}}

Lange DW, Kalra V, Broadbent BH Jr, Powers M, Nelson S. Changes in soft tissue profile following treatment with the bionator. Angle Orthodontist 1995;65(6):423-30.

Lee 2013 \{published data only\}

Lee J, Miyazawa K, Tabuchi M, Kawaguchi M, Shibata M, Goto S. Midpalatal miniscrews and high-pull headgear for anteroposterior and vertical anchorage control: cephalometric comparisons of treatment changes. American Journal of Orthodontics and Dentofacial Orthopedics 2013;144(2):238-50.

\section{Li 2010a \{published data only\}}

Li LG, Zuo YP, Yuan D H. Hard and soft tissue changes following the treatment of Class II division 1 malocclusion using twinblock appliance. Hua Xi Kou Qiang Yi Xue za Zhi [West China Journal of Stomatology] 2010;28(6):637-40.

\section{Li 2010b \{published data only\}}

Li LG, Zuo YP, Yuan DH. Soft tissue changes following the treatment of Class II division 1 malocclusion using Headgearactivator appliance. Shanghai Kou Qiang Yi Xue [Shanghai Journal of Stomatology] 2010;19(6):582-5.

\section{Lima 2013 \{published data only\}}

Lima K J, Henriques J F, Janson G, Pereira S C, Neves L S, Cançado R H. Dentoskeletal changes induced by the Jasper jumper and the activator-headgear combination appliances followed by fixed orthodontic treatment. American Journal of Orthodontics and Dentofacial Orthopedics 2013;143(5):684-94.

\section{Lombardo 2013 \{published data only\}}

Lombardo L, Bragazzi R, Perissinotto C, Mirabella D, Siciliani G. Cone-beam computed tomography evaluation of periodontal and bone support loss in extraction cases. Progress in Orthodontics 2013;14:29. 
Lund 1998 \{published data only\}

Lund DI, Sandler PJ. The effects of Twin Blocks: a prospective controlled study. American Journal of Orthodontics and Dentofacial Orthopedics 1998;113(1):104-10.

\section{Mai 2014 \{published data only\}}

Mai L, Yao Y, Zhang S, Wang D, Zhang Z. Comparison of temporomandibular joint changes in adolescent Class II division 1 malocclusion patients with mandibular retrusion treated with Twin-Block and Class II elastics. Zhonghua Kou Qiang Yi Xue Za Zhi [Chinese Journal of Stomatology] 2014;49(7):394-8.

\section{Malmgren 1987 \{published data only\}}

Malmgren O, Omblus J, Hagg U, Pancherz H. Treatment with an orthopedic appliance system in relation to treatment intensity and growth periods. A study of initial effects. American Journal of Orthodontics and Dentofacial Orthopedics 1987;91(2):143-51.

\section{Malta 2010 \{published data only\}}

Malta LA, Baccetti T, Franchi L, Faltin K Jr, McNamara JA Jr. Long-term dentoskeletal effects and facial profile changes induced by bionator therapy. Angle Orthodontist 2010;80(1):10-7.

\section{Mariani 2014 \{published data only\}}

Mariani L, Maino G, Caprioglio A. Skeletal versus conventional intraoral anchorage for the treatment of class II malocclusion: dentoalveolar and skeletal effects. Progress in Orthodontics 2014;15:43.

\section{Meral 2004 \{published data only\}}

Meral O, Iscan HN, Okay C, Gursoy Y. Effects of bilateral upper first premolar extraction on the mandible. European Journal of Orthodontics 2004;26(2):223-31.

\section{Miles 2016 \{published data only\}}

Miles, P, E. Fisher. Assessment of the changes in arch perimeter and irregularity in the mandibular arch during initial alignment with the AcceleDent Aura appliance vs no appliance in adolescents: a single-blind randomized clinical trial. American journal of orthodontics and dentofacial orthopedics 2016;150:928-936.

\section{Muniandy 2000 \{published data only\}}

Muniandy SD, Battagel JM, Moss JP. A prospective study of the twin block and silensor appliances. European Journal of Orthodontics 2000;22(5):604.

\section{Nelson 2000 \{published data only\}}

Nelson B, Hansen K, Hagg U. Class II correction in patients treated with class II elastics and with fixed functional appliances: a comparative study. American Journal of Orthodontics and Dentofacial Orthopedics 2000;118(2):142-9.

\section{Neves 2014 \{published data only\}}

Neves LS, Janson G, Cançado RH, de Lima KJ, Fernandes TM, Henriques JF. Treatment effects of the Jasper Jumper and the Bionator associated with fixed appliances. Progress in Orthodontics 2014;15:54.
Op Heij 1989 \{published and unpublished data\}

Op Heij DG, Callaert H, Opdebeeck HM. The effect of the amount of protrusion built into the bionator on condylar growth and displacement: a clinical study. American Journal of Orthodontics and Dentofacial Orthopedics 1989;95(5):401-9.

Ozturk 1994 \{published data only\}

Ozturk Y, Tankuter N. Class II: a comparison of activator and activator headgear combination appliances. European Journal of Orthodontics 1994;16(2):149-57.

\section{Pangrazio 1999 \{published data only\}}

Pangrazio-Kulbersh V, Kaczynski R, Shunock M. Early treatment outcome assessed by the Peer Assessment Rating index. American Journal of Orthodontics and Dentofacial Orthopedics 1999;115(5):544-50.

\section{Pangrazio 2003 \{published data only\}}

Pangrazio-Kulbersh V, Berger JL, Chermak DS, Kaczynski R, Simon ES, Haerian A. Treatment effects of the mandibular anterior repositioning appliance on patients with Class II malocclusion. American Journal of Orthodontics and Dentofacial Orthopedics 2003;123(3):286-95.

\section{Parkin 2001 \{published data only\}}

Parkin NA, McKeown HF, Sandler PJ. Comparison of 2 modifications of the twin-block appliance in matched Class II samples. American Journal of Orthodontics and Dentofacial Orthopedics 2001;119(6):572-7.

Patel 2013 \{published data only\}

Patel MP, Henriques JF, de Almeida RR, Pinzan A, Janson G, de Freitas MR. Comparative cephalometric study of Class II malocclusion treatment with Pendulum and Jones jig appliances followed by fixed corrective orthodontics. Dental Press Journal of Orthodontics 2013;18(6):58-64.

\section{Phan 2006 \{published data only\}}

Phan KL, Bendeus M, Hagg U, Hansen K, Rabie AB. Comparison of the headgear activator and Herbst appliance--effects and post-treatment changes. European Journal of Orthodontics 2006;28(6):594-604.

\section{Phelan 2012 \{published data only\}}

Phelan A, Tarraf N E, Taylor P, Hönscheid R, Drescher D, Baccetti T, et al. Skeletal and dental outcomes of a new magnetic functional appliance, the Sydney Magnoglide, in Class II correction. American Journal of Orthodontics and Dentofacial Orthopedics 2012;141(6):759-72.

\section{Pirttiniemi 2005 \{published data only\}}

Mantysaari R, Kantomaa T, Pirttiniemi P, Pykalainen A. The effects of early headgear treatment on dental arches and craniofacial morphology: a report of a 2 year randomized study. European Journal of Orthodontics 2004;26(1):59-64.

* Pirttiniemi P, Kantomaa T, Mantysaari R, Pykalainen A. The effects of early headgear treatment on dental arches and craniofacial morphology: an 8 year report of a randomized study. European Journal of Orthodontics 2005;27(5):429-36. 
Reukers 1998 \{published data only\}

Reukers EA, Sanderink GC, Kuijpers-Jagtman AM, van't Hof MA. Radiographic evaluation of apical root resorption with 2 different types of edgewise appliances. Results of a randomized clinical trial. Journal of Orofacial Orthopedics 1998;59(2):100-9.

Saikoski 2014 \{published data only\}

Saikoski L Z, CanÃßado R H, Valarelli F P, de Freitas K M. Dentoskeletal effects of Class II malocclusion treatment with the Twin Block appliance in a Brazilian sample: a prospective study. Dental Press Journal of Orthodontics 2014;19(1):36-45.

Sari 2003 \{published data only\}

Sari Z, Goyenc Y, Doruk C, Usumez S. Comparative evaluation of a new removable Jasper Jumper functional appliance vs an activator-headgear combination. Angle Orthodontist 2003;73(3):286-93.

\section{Schaefer 2004 \{published data only\}}

Schaefer AT, McNamara JA Jr, Franchi L, Baccetti T. A cephalometric comparison of treatment with the Twin-block and stainless steel crown Herbst appliances followed by fixed appliance therapy. American Journal of Orthodontics and Dentofacial Orthopedics 2004;126(1):7-15.

\section{Shannon 2004 \{published data only\}}

Shannon KR, Nanda RS. Changes in the curve of Spee with treatment and at 2 years posttreatment. American Journal of Orthodontics and Dentofacial Orthopedics 2004;125(5):589-96.

\section{Showkatbakhsh 2013 \{published data only\}}

Showkatbakhsh R, Castaldo M I, Jamilian A, Padricelli G, Fahimi Hanzayi M, Cappabianca S, et al. Treatment effects of R-appliance and Fränkel-2 in Class II division 1 malocclusions. European Journal of Paediatric Dentistry 2013;14(1):17-22.

\section{Siara-Olds 2010 \{published data only\}}

Siara-Olds NJ, Pangrazio-Kulbersh V, Berger J, Bayirli B. Longterm dentoskeletal changes with the Bionator, Herbst, Twin Block, and MARA functional appliances. Angle Orthodontist 2010;80(1):18-29.

\section{Siqueira 2007 \{published data only\}}

Siqueira DF, de Almeira RR, Janson G, Brandao AG, Coelho Filho CM. Dentoskeletal and soft-tissue changes with cervical headgear and mandibular protraction appliance therapy in the treatment of Class II malocclusions. American Journal of Orthodontics and Dentofacial Orthopedics 2007;131(4):447.e21-30.

\section{Song 2008 \{published data only\}}

Song Y, Yu YL, Shen H, Zhang J. Comparative study of the clinical effects of three different functional appliances on the treatment of skeletal class II malocclusion. Hua Xi Kou Qiang Yi Xue za Zhi [West China Journal of Stomatology] 2008;26(4):406-8.

Taner 2003 \{published data only\}

Taner TU, Yukay F, Pehlivanoglu M, Cakirer B. A comparative analysis of maxillary tooth movement produced by cervical headgear and pend-x appliance. Angle Orthodontist 2003;73(6):686-91.

\section{Thuer 1989 \{published data only\}}

Thuer U, Ingervall B, Burgin W. Does the mandible alter its functional position during activator treatment?. American Journal of Orthodontics and Dentofacial Orthopedics 1989;96(6):477-84.

\section{Tumer 1999 \{published data only\}}

Tumer N, Gultan AS. Comparison of the effects of monoblock and twin-block appliances on the skeletal and dentoalveolar structures. American Journal of Orthodontics and Dentofacial Orthopedics 1999;116(4):460-8.

Turkkahraman 2016 \{published data only\}

Turkkahraman H, Eliacik SK, Findik Y. Effects of miniplate anchored and conventional Forsus Fatigue Resistant Devices in the treatment of Class II malocclusion. Angle Orthodontist 2016;86:1026-32.

\section{Ucem 1998 \{published data only\}}

Ucem TT, Yuksel S. Effects of different vectors of forces applied by combined headgear. American Journal of Orthodontics and Dentofacial Orthopedics 1998;113(3):316-23.

Ucuncu 2001 \{published and unpublished data\}

Ucuncu N, Turk T, Carels C. Comparison of modified Teuscher and van Beek functional appliance therapies in high-angle cases. Journal of Orofacial Orthopedics 2001;62(3):224-37.

\section{Uzuner 2014 \{published data only\}}

Uzuner DF, Darendeliler N, Yucel E. Combined fixed-functional treatment of skeletal class II malocclusions with the EVAA appliance: a preliminary study. Journal of Orofacial Orthopedics 2014;75(4):275-86

\section{Wey 2007 \{published data only\}}

Wey MC, Bendeus M, Peng L, Hagg U, Rabie AB, Robinson W. Stepwise advancement versus maximum jumping with headgear activator. European Journal of Orthodontics 2007;29(3):283-93.

\section{Wieslander 1984 \{published data only\}}

Wieslander L. Intensive treatment of severe Class II malocclusions with a headgear-Herbst appliance in the early mixed dentition. American Journal of Orthodontics 1984;86(1):1-13.

\section{Witt 1999 \{published data only\}}

Witt E, Watted N. Effectiveness of intra- and extraoral aids to the bionator. A controlled study within the scope of the "Wuerzburg concept". Journal of Orofacial Orthopedics 1999;60(4):269-78.

\section{Yang 2006 \{published data only\}}

Yang TT, Mi YJ. [Assessment of upper jaw extraction versus upper and lower jaw extraction treatment for class II division 1 malocclusion using peer assessment rating index]. Hua Xi Kou Qiang Yi Xue za Zhi [West China Journal of Stomatology] 2006;24(3):231-3, 239.

\section{You 2006 \{published data only\}}

You Q L, Cai Z. A study of highpull extraoral traction on the treatment of growing patients with skeletal Class II 
malocclusion. Shanghai Kou Qiang Yi Xue [Shanghai Journal of Stomatology] 2006;15(4):375-7.

\section{Additional references}

\section{Antonarakis 2007}

Antonarakis GS, Kiliaridis S. Short-term anteroposterior treatment effects of functional appliances and extraoral traction on class II malocclusion. A meta-analysis. Angle Orthodontist 2007;77(5):907-14

\section{Barnett 2008}

Barnett GA, Higgins DW, Major PW, Flores-Mir C. Immediate skeletal and dentoalveolar effects of the crown- or banded type Herbst appliance on Class II division 1 malocclusion. Angle Orthodontist 2008;78(2):361-9.

\section{Cozza 2006}

Cozza P, Baccetti T, Franchi L, De Toffol L, McNamara JA Jr. Mandibular changes produced by functional appliances in Class II malocclusion: a systematic review. American Journal of Orthodontics and Dentofacial Orthopedics 2006;129(5):599.e1-12; discussion e1-6.

\section{Ehsani 2015}

Ehsani S, Nebbe B, Normando D, Lagravere MO, Flores-Mir C. Short-term treatment effects produced by the Twin-block appliance: a systematic review and meta-analysis. European Journal of Orthodontics 2015;37(2):170-6.

\section{El-Mangoury 1990}

El-Mangoury NH, Mostafa YA. Epidemiologic panorama of dental occlusion. Angle Orthodontist 1990;60(3):207-14.

\section{Flores-Mir 2007}

Flores-Mir C, Ayeh A, Goswani A, Charkhandeh S. Skeletal and dental changes in Class II division 1 malocclusions treated with splint-type Herbst appliances. A systematic review. The Angle Orthodontist 2007;77(2):376-81.

\section{Frujeri 2014}

Frujeri MdeLV, Frujeri JAJ, Bezerra ACB, Cortes MIde SG, Costa $J r$ ED. Socio-economic indicators and predisposing factors associated with traumatic dental injuries in schoolchildren at Brasília, Brazil: a cross-sectional, population-based study. BMC Oral Health 2014;14:91.

\section{Higgins 2011}

Higgins JPT, Green S (editors). Cochrane Handbook for Systematic Reviews of Interventions Version 5.1.0 [updated March 2011]. The Cochrane Collaboration, 2011. Available from handbook.cochrane.org.

\section{Holmes 1992}

Holmes A. The prevalence of orthodontic treatment need. British Journal of Orthodontics 1992;19(3):177-82.

\section{Johal 2007}

Johal A, Cheung MY, Marcene W. The impact of two different malocclusion traits on quality of life. British Dental Journal 2007;202:E2.

\section{Koretsi 2015}

Koretsi V, Zymperdikas VF, Papageorgiou SN, Papadopoulos MA. Treatment effects of removable functional appliances in patients with Class II malocclusion: a systematic review and meta-analysis. European Journal of Orthodontics 2015;37(4):418-34.

\section{Lefebvre 2011}

Lefebvre C, Manheimer E, Glanville J. Chapter 6: Searching for studies. In: Higgins JP, Green S, editor(s). Cochrane Handbook for Systematic Reviews of Interventions Version 5.1.0 (updated March 2011). The Cochrane Collaboration, 2011. Available from handbook.cochrane.org.

\section{Nguyen 1999}

Nguyen QV, Bezemer PD, Habets L, Prahl-Andersen B. A systematic review of the relationship between overjet size and traumatic dental injuries. European Journal of Orthodontics 1999;21(5):503-15.

\section{Pacha 2016}

Pacha MM, Fleming PS, Johal A. A comparison of the efficacy of fixed versus removable functional appliances in children with Class II malocclusion: A systematic review. European Journal of Orthodontics 2016;38(6):621-30.

\section{Perillo 2012}

Perillo L, Cannavale R, Ferro F, Franchi L, Masucci C, Chiodini P, et al. Meta-analysis of skeletal mandibular changes during Frankel appliance treatment. European Journal of Orthodontics 2012;33(1):84-92.

\section{Proffit 1993}

Proffit WR, Fields HW Jr. Contemporary Orthodontics. 2nd Edition. St Louis, USA: Mosby-Year Book, Inc, 1993.

\section{Seehra 2011}

Seehra J, Fleming PS, Newton T, DiBiase AT. Bullying in orthodontic patients and its relationship to malocclusion, self-esteem and oral health-related quality of life. Journal of Orthodontics 2011;38(4):247-56.

\section{Shaw 1980}

Shaw WC, Addy M, Ray C. Dental and social effects of malocclusion and effectiveness of orthodontic treatment: a review. Community Dentistry and Oral Epidemiology 1980;8(1):36-45.

\section{Shaw 1991}

Shaw WC, Richmond S, O'Brien KD, Brook P, Stephens CD. Quality control in orthodontics: indices of treatment need and treatment standards. British Dental Journal 1991;170(3):107-12. 


\section{Silva 2001}

Silva RG, Kang DS. Prevalence of malocclusion among Latino adolescents. American Journal of Orthodontics and Dentofacial Orthopedics 2001;119(3):313-5.

\section{Silva 2016}

Silva LF, Thomaz EB, Freitas HV, Pereira AL, Ribeiro CC, Alves CM. Impact of malocclusion on the quality of life of Brazilian adolescents: A population-based study. PLoS One 2016;11(9):e0162715.

\section{Worthington 2015}

Worthington $\mathrm{H}$, Clarkson J, Weldon J. Priority oral health research identification for clinical decision-making. Evidencebased Dentistry 2015;16(3):69-71.

\section{Yang 2016}

Yang X, Zhu Y, Long H, Zhou Y, Jian F, Ye N, Gao M, Lai W. The effectiveness of the Herbst appliance for patients with Class II malocclusion: a meta-analysis. European Journal of Orthodontics 2016;38(3):324-33.

\section{Zymperdikas 2016}

Zymperdikas VF, Koretsi V, Papageorgiou SN, Papadopoulos MA Treatment effects of fixed functional appliances in patients with

\section{CHARACTERISTICS OF STUDIES}

Characteristics of included studies [ordered by study ID]
Class II malocclusion: a systematic review and meta-analysis. European Journal of Orthodontics 2016;38(2):113-26.

\section{References to other published versions of this review Version 1}

Harrison JE, O'Brien KD, Worthington HV, Bickley SR, Scholey JM, Shaw WC. Orthodontic treatment for prominent upper front teeth in children. Cochrane Database of Systematic Reviews 2002, Issue 1. [DOI: 10.1002/14651858.CD003452]

\section{Version 2}

Harrison JE, O'Brien KD, Worthington HV. Orthodontic treatment for prominent upper front teeth in children. Cochrane Database of Systematic Reviews 2007, Issue 7. [DOI: 10.1002/14651858.CD003452.pub2]

\section{Version 3}

Thiruvenkatachari B, Harrison JE, Worthington HV, O'Brien KD. Orthodontic treatment for prominent upper front teeth (Class II malocclusion) in children. Cochrane Database of Systematic Reviews 2013, Issue 11. [DOI: 10.1002/14651858.CD003452.pub3]

* Indicates the major publication for the study

Alali 2014

\begin{tabular}{|c|c|}
\hline \multirow[t]{5}{*}{ Methods } & Location: Syria \\
\hline & Number of centres: 1 . University of Damascus \\
\hline & Recruitment period: not specified \\
\hline & Funding source: not specified \\
\hline & Trial design: parallel group RCT \\
\hline \multirow[t]{5}{*}{ Participants } & $\begin{array}{l}\text { Inclusion criteria: Class II/1 malocclusion with (overjet }>4 \mathrm{~mm} \text { ); mild to moderate skeletal Class II (ANB } \\
>4^{\circ} \text { and } \mathrm{APg} / \mathrm{NL}<80^{\circ} \text { ) with retrognathic mandible }\left(\mathrm{SNB}<76^{\circ} \text { ); the Fishman method was used to as- }\right. \\
\text { sess the hand-wrist radiographs, and only patients in the pubertal growth spurt peak, which occurs be- } \\
\text { tween stages } 4 \text { and } 7 \text { at the beginning of the treatment/observation period, were invited. }\end{array}$ \\
\hline & Exclusion criteria: none stated \\
\hline & Age at baseline: mean age 13.2 years (SD 0.9) for Group 1 and 12.5 (SD 2.1) years for group 2 \\
\hline & Number randomised: 43 \\
\hline & Number evaluated: 38 \\
\hline \multirow[t]{2}{*}{ Interventions } & Gp $1(n=21)$ : fixed lingual mandibular growth modificator \\
\hline & Gp $2(n=17):$ control - no or delayed treatment \\
\hline Outcomes & Multiple cephalometric variables \\
\hline
\end{tabular}


Alali 2014 (Continued)

Notes
Duration of randomised treatment (months): Gp 1 and Gp $2=8$ months

Sample size calculation: "Clinical and statistical significance in mandibular length change was defined, in the literature, as at least a $+2-\mathrm{mm}$ difference between Class II treated and untreated groups. Based on that difference and standard deviation from previous investigations, a power analysis determined that, for a two-sided $5 \%$ significance level and a power of $80 \%$, a sample size of 16 per group would be required. Accordingly, assignment continued until 25 patients had enrolled in the treatment group to compensate for any unexpected dropouts. In the control group, the enrollment continued until the minimum number of patients required to satisfy the statistical power was reached."

\section{Risk of bias}

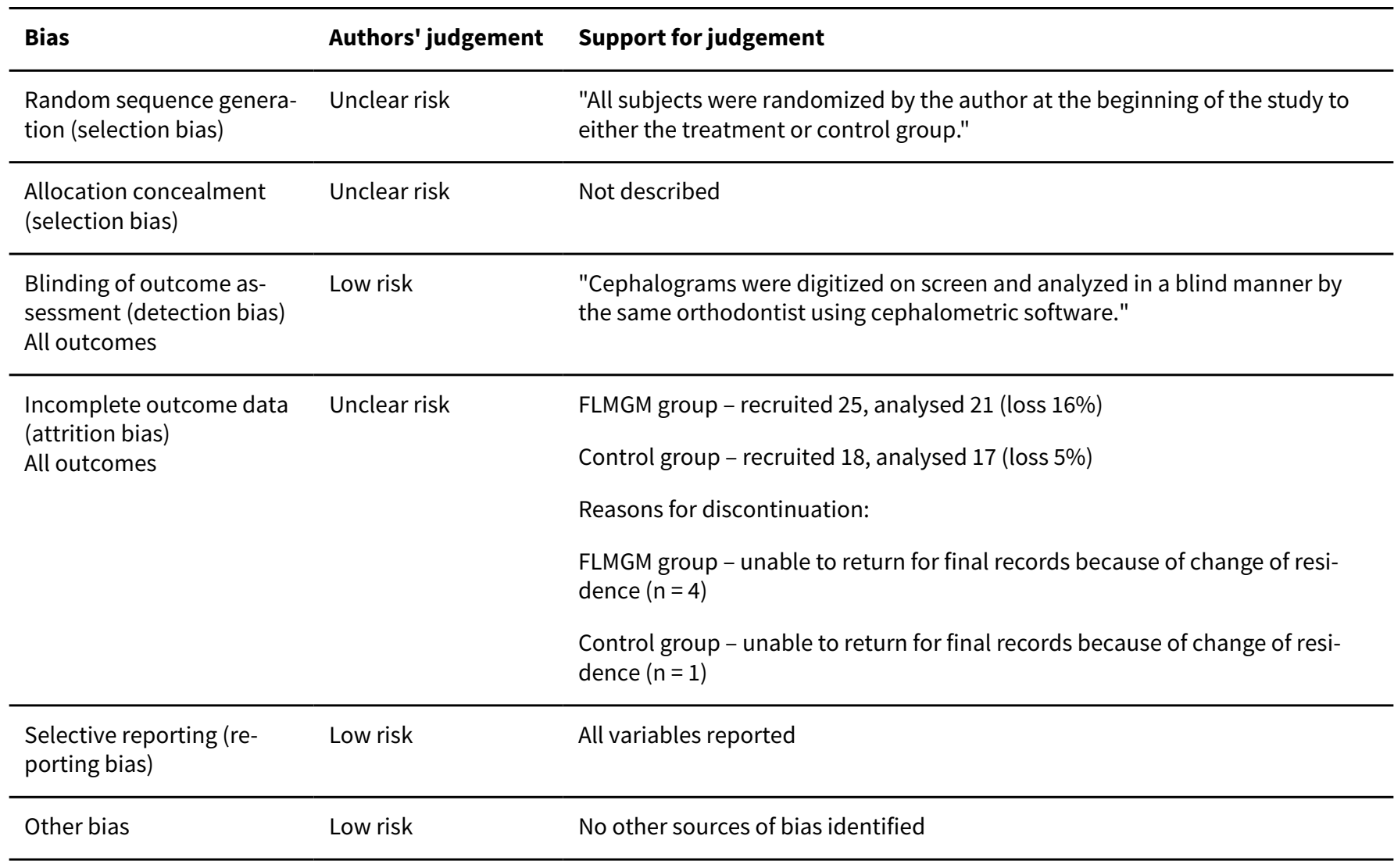

Aras 2017a

$\begin{array}{ll}\text { Methods } & \text { Location: Turkey } \\ & \text { Number of centres: } 1 \\ \text { Recruitment period: not stated } \\ \text { Funding source: not stated } \\ \text { Trial design: parallel group RCT }\end{array}$

Participants

Inclusion criteria: angle Class II Division 1 malocclusion in the permanent dentition with an overjet greater than $6 \mathrm{~mm}$ and full-cusp Cl II molar relationship; ANB greater than 48 with retrognathic mandible; mild or no crowding; growth period just before or at the peak of pubertal growth (evaluated by hand-wrist radiographs); and SN-GoGn not exceeding 388

Exclusion criteria: none stated 
Aras 2017a (Continued)

Age at baseline: Gp 1: 13.48 years (SD 0.88); Gp 2: 13.15 years (SD 0.77); Gp 3: 13.76 years (SD 0.62)

Number randomised: 36 (18 in each group)

Number evaluated: 34 (2 dropouts)

$\begin{array}{ll}\text { Interventions } & \text { Gp } 1(\mathrm{n}=17) \text { : FMA using stepwise mandibular advancement (SWG) } \\ \text { Gp } 2(\mathrm{n}=17) \text { : FMA using single-step advancement (SSG) }\end{array}$

Outcomes Cephalometric radiographs to assess soft tissues and dentoskeletal effects

\begin{tabular}{ll}
\hline Notes & Sample size: "the power analysis with 0.05 level and $80 \%$ power (based on a 0.62-mm standard devia- \\
tion and a $0.6-\mathrm{mm}$ detectable difference), the needed minimum sample size was 17 for each group"
\end{tabular}

\section{Risk of bias}

\begin{tabular}{lll}
\hline Bias & Authors' judgement & Support for judgement \\
\hline $\begin{array}{ll}\text { Random sequence genera- } \\
\text { tion (selection bias) }\end{array}$ & Low risk & $\begin{array}{l}\text { "Matched randomization was used for assigning patients to study groups. Sub- } \\
\text { jects were divided into } 18 \text { pairs using matched randomization based on sex } \\
\text { and a similar degree of malocclusion (considering SNB, ANB, SNGoGn, and } \\
\text { overjet). One patient of each pair, selected at random by tossing a coin, was } \\
\text { treated with FMA utilizing stepwise advancement, while the mandible of the } \\
\text { other patient was progressed in a single step." }\end{array}$ \\
&
\end{tabular}

\begin{tabular}{lll}
\hline $\begin{array}{l}\text { Allocation concealment } \\
\text { (selection bias) }\end{array}$ & Unclear risk & Not reported \\
\hline $\begin{array}{l}\text { Blinding of outcome as- } \\
\text { sessment (detection bias) } \\
\text { All outcomes }\end{array}$ & Low risk & $\begin{array}{l}\text { "Cephalometric measurements were performed in a blinded manner, i.e., the } \\
\text { examiner (A.P.) was unaware of the group assignment." }\end{array}$ \\
\hline
\end{tabular}

\begin{tabular}{|c|c|c|}
\hline $\begin{array}{l}\text { Incomplete outcome data } \\
\text { (attrition bias) } \\
\text { All outcomes }\end{array}$ & Low risk & $\begin{array}{l}\text { Gp 1: recruited } 18 \text {, analysed } 17 \\
\text { Gp 2: recruited 18, analysed } 17 \\
\text { "Because a male patient in the SSG discontinued treatment, the correspond- } \\
\text { ing patient in the other group was excluded from the final analysis to maintain } \\
\text { a } 1: 1 \text { intergroup ratio. Data for } 34 \text { subjects were collected." }\end{array}$ \\
\hline $\begin{array}{l}\text { Selective reporting (re- } \\
\text { porting bias) }\end{array}$ & Low risk & Expected outcomes reported \\
\hline Other bias & Low risk & No other sources of bias identified \\
\hline
\end{tabular}

Aras 2017b

\begin{tabular}{ll} 
Methods & Location: Ege University, Turkey \\
& Number of centres: 1 \\
Recruitment period: not stated \\
Funding source: not stated \\
Trial design: parallel group RCT \\
\hline
\end{tabular}


Aras 2017b (Continued)

Participants
Inclusion criteria: angle Class II subdivision malocclusion in the permanent dentition, based on the presence of Class I molar relationship on one side and at least end-to-end Class II molar relationship on the other; absence of severe crowding; normal or slightly increased overbite; mild or moderately increased overjet; maxillary midline coincident with facial midline; mandibular midline deviation to the Class II side; and no functional lateral mandibular shift during closure (determined by clinical examination)

Exclusion criteria: none stated

Age at baseline: Gp 1: 14.19 years (SD 1.02); Gp 2: 13.75 years (SD 1.16)

Number randomised: 34 (17 in each group)

Number evaluated: 28 (6 dropouts)

\begin{tabular}{ll}
\hline Outcomes & Cephalometric radiographs to assess soft tissues and dentoskeletal effects \\
& Model measurement for molar relationship and centrelines \\
\hline Notes & $\begin{array}{l}\text { Sample size: "According to the power analysis with } 0.05 \text { level and } 80 \% \text { power (based on a } 1.32 \text {-mm } \\
\text { standard deviation and a } 1.5 \text {-mm detectable difference for midline correction), the needed minimum } \\
\text { sample size was } 12 \text { for each group." }\end{array}$
\end{tabular}

\section{Risk of bias}

\begin{tabular}{lll}
\hline Bias & Authors' judgement & Support for judgement \\
\hline $\begin{array}{l}\text { Random sequence genera- } \\
\text { tion (selection bias) }\end{array}$ & Low risk & "Matched randomization was used for allocation of patients to the two study \\
& & $\begin{array}{l}\text { groups. Subjects were divided into } 17 \text { pairs. Patients within each pair were se- } \\
\text { lected so that they had a similar degree of malocclusion (based on overjet, } \\
\text { molar relationship, and crowding). One of the patients in each pair, randomly }\end{array}$ \\
& $\begin{array}{l}\text { selected through tossing a coin, received fixed appliance treatment with the } \\
\text { Forsus group (Forsus FRD) whereas the other patient received fixed appliance } \\
\text { treatment with intermaxillary elastics (elastics group)" }\end{array}$
\end{tabular}

\begin{tabular}{lll}
\hline $\begin{array}{l}\text { Allocation concealment } \\
\text { (selection bias) }\end{array}$ & Unclear risk & Not reported \\
\hline $\begin{array}{l}\text { Blinding of outcome as- } \\
\text { sessment (detection bias) } \\
\text { All outcomes }\end{array}$ & Low risk & $\begin{array}{l}\text { "Appraisal of all cephalometric radiographs and digital models were carried } \\
\text { out by one examiner in a blinded manner." }\end{array}$ \\
\hline
\end{tabular}

All outcomes

Incomplete outcome data Low risk

(attrition bias)

All outcomes

\begin{abstract}
"Two patients were removed from the elastics groups due to poor cooperation on elastics wear. Also, after leveling and alignment, the Class II molar relationship turned into a Class I in one of the Forsus patients. These and the corresponding patients in the other group were excluded from the final analysis to maintain the 1:1 intergroup ratio. Thus, 28 patients were included in the final assessment"
\end{abstract}

All relevant outcomes reported

Selective reporting (re- Low risk All relevant outcomes reported
porting bias)

Other bias

High risk

Gender bias: $\mathrm{M}: \mathrm{F}=8: 20$ 


\section{Banks 2004}

\begin{tabular}{|c|c|}
\hline \multirow[t]{5}{*}{ Methods } & Location: United Kingdom \\
\hline & Number of centres: 3 centres, 4 operators \\
\hline & Recruitment period: not stated \\
\hline & Funding source: British Orthodontic Society 1998 Research \& Audit award \\
\hline & Trial design: parallel group RCT \\
\hline \multirow[t]{5}{*}{ Participants } & $\begin{array}{l}\text { Inclusion criteria: overjet of } 7 \mathrm{~mm} \text { or more; no previous appliance therapy; permanent dentition stage, } \\
\text { age } 10 \text { to } 14 \text { years; and no significant medical history }\end{array}$ \\
\hline & Exclusion criteria: none stated \\
\hline & Age at baseline: mean age group 12.6 years \\
\hline & Number randomised: 203 (14 incorrectly included or protocol deviation), 189 started treatment \\
\hline & Number evaluated: 136 (76/95 and 60/94) \\
\hline \multirow[t]{2}{*}{ Interventions } & Gp A $(n=95)$ : Twin Block with stepwise incremental advancement \\
\hline & Gp B $(n=94):$ Twin Block with single step advancement \\
\hline Outcomes & All Cephalometric variables, duration of treatment and carstairs social deprivation score \\
\hline \multirow[t]{2}{*}{ Notes } & Duration of randomised treatment (months): $\mathrm{Gp} \mathrm{A}=7.02$ (6.34 to 7.70 ), $\mathrm{Gp} B=7.40$ (6.71 to 8.09) \\
\hline & $\begin{array}{l}\text { Sample size calculation: "A } 20 \% \text { difference between the groups in compliance rate was thought to be } \\
\text { clinically significant. On this basis, with alpha at } 0.05 \text { and the study power at } 0.85 \text {, we needed } 80 \text { pa- } \\
\text { tients per group. To allow for } 20 \% \text { treatment discontinuation, we recruited over } 200 \text { patients with an in- } \\
\text { tention to treat analysis." }\end{array}$ \\
\hline
\end{tabular}

\section{Risk of bias}

\begin{tabular}{lll}
\hline Bias & Authors' judgement & Support for judgement \\
\hline $\begin{array}{l}\text { Random sequence genera- } \\
\text { tion (selection bias) }\end{array}$ & Low risk & $\begin{array}{l}\text { "The patients were randomized to either the control or the experimental } \\
\text { group". The randomisation was made at the start of the study with pre-pre- } \\
\text { pared random number tables with a block stratification on centre and sex (un- } \\
\text { published data). }\end{array}$ \\
\hline $\begin{array}{l}\text { Allocation concealment } \\
\text { (selection bias) }\end{array}$ & Low risk & $\begin{array}{l}\text { "We performed manual allocation using sealed envelopes to blind the opera- } \\
\text { tor during enrolment of patients in the study." }\end{array}$ \\
\hline $\begin{array}{l}\text { Blinding of outcome as- } \\
\text { sessment (detection bias) } \\
\text { All outcomes }\end{array}$ & Low risk & $\begin{array}{l}\text { "When measuring the cephalograms, the examiner was unaware of the group } \\
\text { to which the patient had been allocated." }\end{array}$ \\
\hline $\begin{array}{l}\text { Incomplete outcome data } \\
\text { (attrition bias) } \\
\begin{array}{l}\text { All outcomes } \\
\hline\end{array}\end{array}$ & High risk & Experimental group - recruited 95, completed 76 (loss 20\%) \\
\hline
\end{tabular}


Banks 2004 (Continued)

Reasons for discontinuation not specified

Selective reporting (re- Low risk All variables reported

porting bias)

Other bias Low risk No other sources of bias identified

Baysal 2014

Methods
Number of centres: 1
Recruitment period: February 2007 to June 2009
Funding source: research grant from Erciyes University (SBT-07-36).
Trial design: parallel group RCT

Trial design: parallel group RCT

\begin{abstract}
Participants Inclusion criteria: skeletal Class II relationship (ANB $>4^{\circ}$ ); mandibular retrognathy $\left(\mathrm{SNB}<78^{\circ}\right)$; overjet $\geq$ $5 \mathrm{~mm}$; SN-GoGn $=32^{\circ} \pm 6^{\circ}$; minimal crowding in dental arches $(\leq 4 \mathrm{~mm})$; bilateral Class II molar and canine relation (at least $3.5 \mathrm{~mm}$ ); patients with fourth ( $\mathrm{S}$ and H2) or fifth (MP3cap, PP1cap, Rcap) epiphyseal stages on hand-wrist radiographs, as defined by Björk (1972)

Exclusion criteria: no history of orthodontic treatment either prior to or during functional appliance therapy; congenitally missing or extracted permanent tooth (except third molars); posterior crossbites or severe maxillary transverse deficiency; severe facial asymmetry determined by clinical or radiographical examination; poor oral hygiene; systemic diseases that may affect the orthodontic treatment results.
\end{abstract}

Age at baseline: Herbst group - mean age $=12.74$ years $(S D=1.43) ;$ Twin Block group - mean age $=13.0$ years $(S D=1.32)$; Control group - mean age $=12.17$ years $(S D=1.47)$

Number randomised: 47

Number evaluated: 40

\begin{tabular}{ll}
\hline Interventions & Gp A $(n=23)$ : Herbst appliance \\
$G p B(n=24):$ Twin Block
\end{tabular}

Outcomes Cephalometric radiographs to assess soft tissues and dentoskeletal effects

Notes

Duration of active treatment - 16.2 months (Twin-Block) + recruited period ( 2 years and 4 months)

Sample size: the sample size for the groups was calculated based on a significance level of 0.05 and a power of 80 per cent to detect a clinically meaningful difference of $1 \mathrm{~mm}( \pm 1.5 \mathrm{~mm})$ for the distance of the lower lip to E plane between the three groups. The power analysis showed that 18 participants in each group were required.

\title{
Risk of bias
}

\begin{tabular}{lll}
\hline Bias & Authors' judgement & Support for judgement \\
\hline $\begin{array}{ll}\text { Random sequence genera- } \\
\text { tion (selection bias) }\end{array}$ & Low risk & "Randomization was made at this stage according to previously prepared ran- \\
& & dom number tables with block stratification on gender. Twenty-three patients \\
& were included in the Herbst group and 24 patients were enrolled in the TB \\
& group. The control group comprised 20 subjects who refused treatment after
\end{tabular}


Baysal 2014 (Continued)

initial records were taken with excuses such as college entrance examination, problems in medical insurance system, or refusal to wear appliance."

\begin{tabular}{|c|c|c|}
\hline $\begin{array}{l}\text { Allocation concealment } \\
\text { (selection bias) }\end{array}$ & Unclear risk & Concealment approach not specified \\
\hline $\begin{array}{l}\text { Blinding of outcome as- } \\
\text { sessment (detection bias) } \\
\text { All outcomes }\end{array}$ & High risk & "Cephalometric tracings were performed by the same author (AB) manually." \\
\hline $\begin{array}{l}\text { Incomplete outcome data } \\
\text { (attrition bias) } \\
\text { All outcomes }\end{array}$ & Low risk & $\begin{array}{l}\text { Herbst group - recruited 23, analysed } 20 \text { (loss } 13 \%) \\
\text { TB group - recruited } 24 \text {, analysed } 20 \text { (loss } 16 \%) \\
\text { Reasons for discontinuation: } \\
\text { Herbst group - poor oral hygiene and progression of white spot lesions }(n=1) \text {; } \\
\text { non-compliance }(n=1) \\
\text { TB group - lost to follow up }(n=1) \text {; hospitalised for a systemic disease }(n= \\
\text { 1); no longer wanted treatment }(n=1) \text {; poor oral hygiene and progression of } \\
\text { white spot lesions }(n=1)\end{array}$ \\
\hline $\begin{array}{l}\text { Selective reporting (re- } \\
\text { porting bias) }\end{array}$ & Low risk & All cephalometric variables reported \\
\hline Other bias & Low risk & No other source of bias identified \\
\hline
\end{tabular}

\section{Bilgiç 2011}

\begin{tabular}{ll}
\hline Methods & Location: Diyarbakir, Turkey \\
& Number of centres: 1: Dicle University, Turkey \\
& Recruitment period: not specified \\
& Funding source: not specified \\
Trial design: parallel group
\end{tabular}

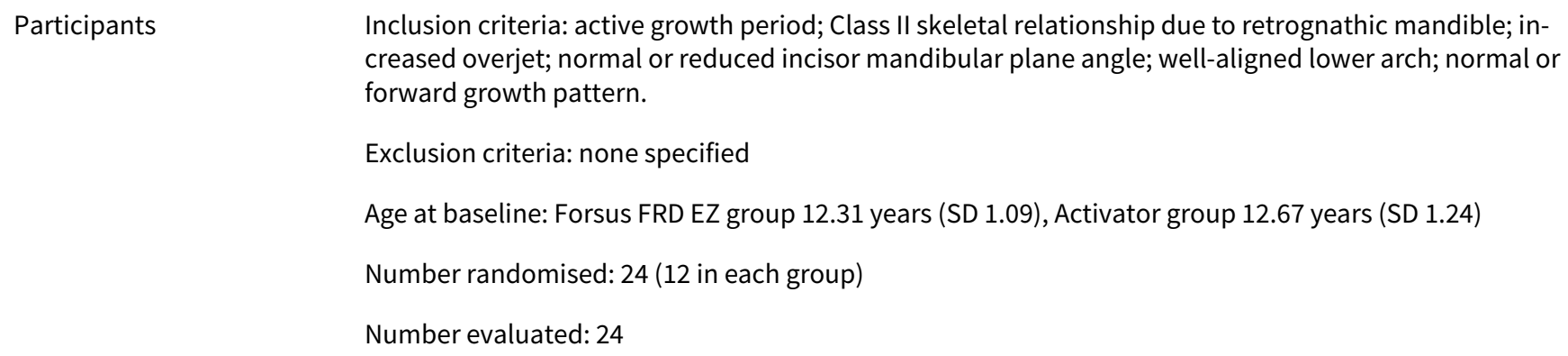
creased overjet; normal or reduced incisor mandibular plane angle; well-aligned lower arch; normal or forward growth pattern.

Exclusion criteria: none specified

Age at baseline: Forsus FRD EZ group 12.31 years (SD 1.09), Activator group 12.67 years (SD 1.24)

Number randomised: 24 (12 in each group)

Number evaluated: 24

Interventions
Gp A $(n=12)$ : Forsus FRD EZ fixed functional appliance
Gp B $(n=12)$ : Activator (Andresent-type) appliance

\begin{tabular}{ll}
\hline Outcomes & All cephalometric variables reported \\
\hline Notes & Duration of active treatment -6 months
\end{tabular}


Sample size: "A power test (Minitab 14.0) between pre-treatment and post-treatment primary result variables determined that a minimum of 20 subjects was necessary for difference comparisons."

\section{Risk of bias}

\begin{tabular}{|c|c|c|}
\hline Bias & Authors' judgement & Support for judgement \\
\hline \multirow[t]{2}{*}{$\begin{array}{l}\text { Random sequence genera- } \\
\text { tion (selection bias) }\end{array}$} & High risk & $\begin{array}{l}\text { "The patients were randomly divided into two groups" and "Patients were se- } \\
\text { lected and matched" }\end{array}$ \\
\hline & & Method of sequence generation not described \\
\hline $\begin{array}{l}\text { Allocation concealment } \\
\text { (selection bias) }\end{array}$ & Unclear risk & Not described \\
\hline $\begin{array}{l}\text { Blinding of outcome as- } \\
\text { sessment (detection bias) } \\
\text { All outcomes }\end{array}$ & Unclear risk & Not described \\
\hline $\begin{array}{l}\text { Incomplete outcome data } \\
\text { (attrition bias) } \\
\text { All outcomes }\end{array}$ & Low risk & No dropouts or losses to follow-up mentioned. 24 randomised and 24 analysed \\
\hline $\begin{array}{l}\text { Selective reporting (re- } \\
\text { porting bias) }\end{array}$ & Low risk & All variables reported \\
\hline Other bias & Low risk & No other source of bias identified \\
\hline
\end{tabular}

\section{Burhan 2015}

Location: Damascus, Syria
Number of centres: 1 . Al Baath University, Syria
Recruitment period: registered patients in pending records
Funding source: not specified
Trial design: parallel group RCT

Participants

Inclusion criteria: skeletal Class II division 1 malocclusion resulting from the retrusion of the mandible (SNB angle $<78^{\circ}$ ); convex facial profile; ANB angle $>4^{\circ}$; good mouth health; no previous orthodontic treatments; pubertal growth spurt peak at the beginning of the treatment, which was assessed using hand-wrist radiographs according to the Fishman method

Exclusion criteria: none specified

Age at baseline: Bite Jumping Appliance group 11.5 years (SD 1.0), Twin Block 11.8 years (SD 0.9)

Number randomised: 44 (22 in each group)

Number evaluated: 40
Interventions
Gp A ( $n=20)$ : Bite jumping appliance - removable functional appliance
Gp B ( $n=20)$ : Twin Block appliance - removable functional appliance 
Burhan 2015 (Continued)

Outcomes

Using cephalometric radiograms, the dentoalveolar and skeletal effects resulting from both appliances were detected.

Notes

Duration of active treatment -12 months + recruited period (not reported)

Sample size: to determine the appropriate sample size, the Minitab software was used with two-sample t-tests, a selected study power of $80 \%$, a significance level of 0.05 , and a detected difference of $1^{\circ}$. The used standard deviation (SD) of $1.09^{\circ}$ was based on a pilot study of 10 cases (five in each group). The appropriate sample size was 20 patients in each group. This number was increased to 22 participants to compensate for the potential dropouts.

\section{Risk of bias}

\begin{tabular}{|c|c|c|}
\hline Bias & Authors' judgement & Support for judgement \\
\hline $\begin{array}{l}\text { Random sequence genera- } \\
\text { tion (selection bias) }\end{array}$ & Low risk & $\begin{array}{l}\text { A computer-generated randomisation list was used to randomly divide the pa- } \\
\text { tients into two equal groups. }\end{array}$ \\
\hline $\begin{array}{l}\text { Allocation concealment } \\
\text { (selection bias) }\end{array}$ & Unclear risk & Not described \\
\hline $\begin{array}{l}\text { Blinding of outcome as- } \\
\text { sessment (detection bias) } \\
\text { All outcomes }\end{array}$ & Low risk & $\begin{array}{l}\text { Blinding of assessment was performed by (ASB) coding names of patients on } \\
\text { pre- and post-treatment cephalograms, and tracing and measurements were } \\
\text { performed by (FRN), so that the group each participant belonged to was un- } \\
\text { known when the records were evaluated. }\end{array}$ \\
\hline \multirow{5}{*}{$\begin{array}{l}\text { Incomplete outcome data } \\
\text { (attrition bias) } \\
\text { All outcomes }\end{array}$} & Low risk & BJA group - recruited 22 , completed 20 (loss $10 \%)$ \\
\hline & & TB group - recruited 22, completed 20 (loss $10 \%$ ) \\
\hline & & Reasons for discontinuation: \\
\hline & & BJA group - failed to return for follow-up appointments $(n=2)$ \\
\hline & & $\begin{array}{l}\text { TB group - failed to return for follow up appointments }(n=1) \text {; uncooperative } \\
\text { patients }(n=1)\end{array}$ \\
\hline $\begin{array}{l}\text { Selective reporting (re- } \\
\text { porting bias) }\end{array}$ & Low risk & All variables reported \\
\hline Other bias & Low risk & No other source of bias identified \\
\hline
\end{tabular}

Cevidanes 2003

Methods $\quad$ Location: North Carolina, Brazil and Ohio
Number of centres: 1: Sao Paulo, Brazil
Recruitment period: not specified
Funding source: grants from FAPESP and CNPq, Brazil

Trial design: parallel group RCT

Participants Inclusion criteria: Class II Division 1 malocclusion, with greater than or equal to three-fourths cusp Class II molars and overjet ranging from $4.5 \mathrm{~mm}$ to $10 \mathrm{~mm}$

Exclusion criteria: none specified 
Cevidanes 2003 (Continued)

Age at baseline: Frankel group 10.3 years (SD 0.9), untreated control group 10.9 years (SD 0.7)

Number randomised: 56 (28 in each group)

Number evaluated: not reported

\begin{tabular}{ll}
\hline Interventions & Gp A: Frankel appliance \\
& Gp B: Untreated control \\
\hline Outcomes & Counterpart analysis using cephalogram. Measurements included: \\
- mandibular retrusive/protrusive effects; \\
- middle cranial fossa and posterior maxilla relative alignment; \\
- ramus alignment; \\
- ramus/middle cranial fossa relative to posterior maxilla vertical dimension;
\end{tabular}

Notes Duration of randomised treatment 18 months

Sample size calculation not reported

\section{Risk of bias}

\begin{tabular}{|c|c|c|}
\hline Bias & Authors' judgement & Support for judgement \\
\hline \multirow[t]{2}{*}{$\begin{array}{l}\text { Random sequence genera- } \\
\text { tion (selection bias) }\end{array}$} & Unclear risk & $\begin{array}{l}\text { "Class II children were randomly allocated to } 2 \text { subgroups, treated and control, } \\
\text { to avoid bias in the group comparison." }\end{array}$ \\
\hline & & Method of sequence generation not reported \\
\hline $\begin{array}{l}\text { Allocation concealment } \\
\text { (selection bias) }\end{array}$ & Unclear risk & Not described \\
\hline $\begin{array}{l}\text { Blinding of outcome as- } \\
\text { sessment (detection bias) } \\
\text { All outcomes }\end{array}$ & Low risk & "Tracings were performed with blinding procedure." \\
\hline $\begin{array}{l}\text { Incomplete outcome data } \\
\text { (attrition bias) } \\
\text { All outcomes }\end{array}$ & Unclear risk & $\begin{array}{l}\text { 2-phase trial. Unclear data. Number of children evaluated at } 18 \text { months not } \\
\text { stated }\end{array}$ \\
\hline $\begin{array}{l}\text { Selective reporting (re- } \\
\text { porting bias) }\end{array}$ & Unclear risk & $\begin{array}{l}\text { The authors have not reported regular cephalometric variables. They have } \\
\text { done counterpart analysis which does not include regular cephalometric mea- } \\
\text { surements. }\end{array}$ \\
\hline Other bias & Unclear risk & Baseline characteristics (gender) not reported \\
\hline
\end{tabular}

Cirgić 2016

Location: general dental practices (GDP) in Sweden
Number of centres: 12 general dental practices at the Public Dental Health Services, Region Västra Gö-
taland
Recruitment period: 2007 to 2010 . "However, it took long time to recruit patients so we decided to stop
when 105 participants were involved in the study."


Cirgić 2016 (Continued)

Funding source: The Council for Research and Development in the Västra Götaland Region, Gothenburg Dental Society and Swedish Dental Society

Trial design: parallel group RCT

Participants

Inclusion criteria: 6 to 14 years old with central incisors erupted, Angle Class II division 1, increased overjet $\geq 6 \mathrm{~mm}$ or less if lip incompetence was present, no previous orthodontic treatment

Exclusion criteria: crossbite, severe crowding, agenesis, other malocclusions

and syndromes

Age at baseline: 97 participants (44 girls, 53 boys), mean age was 10.3 years (SD 1.64; range 7 to 14 years)

Number randomised: 105

Number evaluated: 97

Interventions

Gp $1(n=40)$ : modified Andresen activator (AA)

Gp 2 ( $n=57)$ : prefabricated functional appliances (PFAs)
Overjet change, molar relationship, overbite and lip seal, treatment time and success rate

"According to a sample size analysis, 38 patients per group were required to obtain adequate power (80 per cent, at significance level $P<0.05$ with an standard deviation (SD) of 1.3 and with the loss of 10 patients), based on a clinically significant difference of $1 \mathrm{~mm}$ in overjet reduction between the study groups."

"No harms were detected during the study."

\section{Risk of bias}

Bias Authors' judgement Support for judgement

Random sequence genera- Unclear risk "Patients were randomly allocated by lottery"

tion (selection bias)

"As we expected a high risk of dropouts and non-compliant patients, as seen in previous studies we aimed for 240 patients in total, compared with 76 patients required according to sample size analysis. However, it took long time to recruit patients so we decided to stop when 105 participants were involved in the study. This was the reason for the uneven randomization."

\begin{tabular}{ll}
\hline $\begin{array}{l}\text { Allocation concealment } \\
\text { (selection bias) }\end{array}$ & Unclear risk \\
\end{tabular}

\begin{tabular}{lll}
\hline $\begin{array}{l}\text { Blinding of outcome as- } \\
\begin{array}{l}\text { sessment (detection bias) } \\
\text { All outcomes }\end{array}\end{array}$ & High risk & "Blinding was not performed" \\
\hline $\begin{array}{l}\text { Incomplete outcome data } \\
\text { (attrition bias) }\end{array}$ & Unclear risk & $\begin{array}{l}\text { Clinical measurements: } 105 \text { recruited; } 97 \text { randomised and reported. Gp 1: } 62 \\
\text { randomised and } 57 \text { (85\%) reported; Gp 2: } 43 \text { randomised and 40 (87\%) report- } \\
\text { ed. outcomes }\end{array}$ \\
& $\begin{array}{l}\text { For the questionnaire Gp 1: } 40 \text { randomised and 20 analysed (50\%), Gp 2: } 57 \\
\text { randomised and 24 reported (42\%) }\end{array}$ \\
\hline $\begin{array}{l}\text { Selective reporting (re- } \\
\text { porting bias) }\end{array}$ & Low risk & All variables reported \\
\hline
\end{tabular}


Cirgić 2016 (Continued)

Other bias Unclear risk Uneven randomisation. "As we expected a high risk of dropouts and non-compliant patients, as seen in previous studies we aimed for 240 patients in total, compared with 76 patients required according to sample size analysis. However, it took long time to recruit patients so we decided to stop when 105 participants were involved in the study. This was the reason for the uneven randomization."

\section{Cura 1997}

\begin{tabular}{|c|c|}
\hline \multirow[t]{5}{*}{ Methods } & Location: Turkey \\
\hline & Number of centres: 1 \\
\hline & Recruitment period: not stated \\
\hline & Funding source: University of Istanbul Research Fund \\
\hline & Trial design: parallel group RCT \\
\hline
\end{tabular}

Participants Inclusion criteria: children with Class II Division 1 malocclusion, defined by Class II molar relationship and ANB difference of $5^{\circ}$

Exclusion criteria: poor co-operation

Age at baseline: 11 years

Number randomised: 60 (35 and 25 to Bass and control groups)

Number evaluated: 47 (27/35 and 20/25 respectively)

\begin{tabular}{ll}
\hline Interventions & Gp A $(n=27):$ Bass functional appliance \\
& Gp B $(n=20)$ : untreated control
\end{tabular}

\begin{tabular}{ll}
\hline Outcomes & Skeletal discrepancy measured by ANB on cephalogram, skeletal development \\
\hline Notes & Duration of randomised treatment: 6 months \\
& Sample size calculation: not reported \\
\hline
\end{tabular}

\section{Risk of bias}

Bias Authors' judgement Support for judgement

\section{Random sequence genera- Unclear risk} tion (selection bias) "The sample was randomly divided into a treatment group of 35 cases and a
control group of 25 cases."

Method of sequence generation not described

\begin{tabular}{lll}
\hline $\begin{array}{l}\text { Allocation concealment } \\
\text { (selection bias) }\end{array}$ & Unclear risk & Not described \\
\hline $\begin{array}{l}\text { Blinding of outcome as- } \\
\text { sessment (detection bias) } \\
\text { All outcomes }\end{array}$ & Unclear risk & Blinded assessment not reported \\
\hline $\begin{array}{l}\text { Incomplete outcome data } \\
\text { (attrition bias) }\end{array}$ & High risk & $\begin{array}{l}13 \text { dropouts (22\%). 8/35 participants in treatment group and 5/25 in control } \\
\text { All outcomes }\end{array}$ \\
\hline
\end{tabular}


Cura 1997 (Continued)

Dropout participants not included in analysis, but percentage similar in each group

\begin{tabular}{lll}
\hline $\begin{array}{l}\text { Selective reporting (re- } \\
\text { porting bias) }\end{array}$ & Low risk & All outcome variables reported \\
\hline Other bias & High risk & Gender imbalance at baseline \\
\hline
\end{tabular}

\section{Eissa 2017}

\begin{tabular}{ll}
\hline Methods & Location: Tanta, Egypt \\
& Number of centres: 1 \\
& Recruitment period: not reported \\
& Funding source: not reported \\
& Trial design: parallel group RCT
\end{tabular}

Inclusion criteria: skeletal Class II malocclusion with mandibular retrognathia
normal vertical growth pattern (SN-MP angle in 258 to 358 range); minimal or
mandibular arch (0 to $5 \mathrm{~mm}$ ), based on Little's irregularity index; no extracted
teeth (third molars excluded); undergoing circumpubertal phase of skeletal deve
no medical history or systemic disease that could affect normal growth of the
Exclusion criteria: not reported
Age at baseline: Gp 1: 12.76 (SD 1.0); Gp 2: 12.52 (SD 1.12); Gp 3: 12.82 (SD 0.9)
Number randomised: 45
Number evaluated: 38

Interventions

Gp 1: conventional FRD

Gp 2: miniscrew-anchored FRD

Gp 3: untreated control

\begin{tabular}{|c|c|c|}
\hline Outcomes & \multicolumn{2}{|c|}{ All cephalometric variables, success rate for screws and harms } \\
\hline Notes & \multicolumn{2}{|c|}{$\begin{array}{l}\text { "Sample size calculation was based on the ability to detect a clinically meaningful difference in } \\
\text { mandibular length of } 2 \mathrm{~mm}(61.5 \mathrm{~mm}) \text {, with an alpha error of } 0.05 \text { and a test power of } 80 \% \text {. The calcu- } \\
\text { lation was carried out using software } \mathrm{G}^{\star} \text { Power (Universitat Dusseldorf, Germany). The recommended } \\
\text { sample size was } 12 \text { patients in each group. To compensate for a possible dropout rate of } 20 \% \text { during } \\
\text { the study period, } 15 \text { patients were included in each group." }\end{array}$} \\
\hline \multicolumn{3}{|l|}{ Risk of bias } \\
\hline Bias & Authors' judgement & Support for judgement \\
\hline $\begin{array}{l}\text { Random sequence genera- } \\
\text { tion (selection bias) }\end{array}$ & Low risk & "Patients were randomly assigned using a computer generated random list." \\
\hline $\begin{array}{l}\text { Allocation concealment } \\
\text { (selection bias) }\end{array}$ & Low risk & $\begin{array}{l}\text { "The patients were randomly allocated into three groups using sequentially } \\
\text { numbered, opaque, sealed envelopes." }\end{array}$ \\
\hline
\end{tabular}


Eissa 2017 (Continued)

Blinding of outcome as sessment (detection bias)

All outcomes
Unclear risk $\quad$ "...the investigator who analyzed the cephalograms was blinded regarding the origin of the films and the group to which the individual subjects belonged.

All data were labeled with numbers and sent to the statistician, who was also blinded to the patients' groups. For the control group, it was impossible to be completely blinded as there were no appliances in the patients' mouths, but blinding was achieved regarding the time point of the cephalograms."
Incomplete outcome data Unclear risk
Gp 1: recruited 15, analysed 14
(attrition bias)
All outcomes
Gp 2: recruited 15, analysed 15
Gp 3: recruited 15, analysed 9
Uneven dropout rate between groups

\begin{tabular}{lll}
\hline $\begin{array}{l}\text { Selective reporting (re- } \\
\text { porting bias) }\end{array}$ & Low risk & All variables reported \\
\hline Other bias & Low risk & No other source of bias identified \\
\hline
\end{tabular}

Elkordy 2016

\begin{tabular}{|c|c|}
\hline \multirow[t]{5}{*}{ Methods } & Location: Cairo, Egypt \\
\hline & Number of centres: 1 \\
\hline & Recruitment period: from June 2012 to December 2013 \\
\hline & Funding source: self-funded by the authors \\
\hline & Trial design: parallel group RCT \\
\hline
\end{tabular}

Participants

Inclusion criteria: females 11 to 14 years old; skeletal angle Class II division 1 malocclusion with a deficient mandible $\left(\mathrm{SNB} \leq 76^{\circ}\right)$; horizontal or neutral growth pattern (MMP $\leq 30^{\circ}$ ); increased overjet (minimum $5 \mathrm{~mm}$ ) with Class II canine relationship (minimum of half unit); erupted full set of permanent teeth with mandibular arch crowding less than $3 \mathrm{~mm}$; at the time of insertion of the FFRD, the patients had to be in the MP3 G or MP3 H stage according to Rajagopal

Exclusion criteria: systemic disease; any signs or symptoms of temporomandibular dysfunction; extracted or missing permanent tooth/teeth; facial asymmetry; parafunctional habits; severe proclination or crowding that requires extractions in the lower arch

Age at baseline: FFRD - 16 females (13.25 SD 1.12); FMI - 15 females (13.07 SD 1.41); control (12.71 SD 1.44)

Number randomised: 46

Number evaluated: 43

Interventions
Gp A ( $=16 / 16)$ : Forsus Fatigue Resistance Device (FFRD)
Gp B ( $n=15 / 15)$ : Forsus Fatigue Resistance Device with mini-implant (FMI)
Gp C $(n=15 / 12)$ : control/no intervention

Outcomes

(i) Overjet

(ii) Skeletal changes

(iii) Dentoalveolar changes 
Elkordy 2016 (Continued)

(iv) Patient satisfaction

Dotes
$\begin{aligned} & \text { Duration of randomised treatment: } \\ & \text { - FFRD - } 4.86 \text { (SD 1.32) }\end{aligned}$
Sample size calculation: sample size calculation was done using G power software (Universität Düs-
seldorf, Düsseldorf, Germany), with an alpha value of 0.05 and a power of $80 \%$ based on the study by
Weschler and Pancherz and revealed the need for 12 participants per group.

\section{Risk of bias}

\section{Bias Authors' judgement Support for judgement}

Random sequence genera- Low risk $\quad$ "A computer-generated random list was created (https://www.ran-
tion (selection bias) dom.org/).... The patients were randomly allocated into three groups..."

The control group arm was not reported in the first part of the study.

\begin{tabular}{lll}
\hline $\begin{array}{l}\text { Allocation concealment } \\
\text { (selection bias) }\end{array}$ & Low risk & "...and allocation concealment was achieved with opaque sealed envelopes." \\
\hline $\begin{array}{l}\text { Blinding of outcome as- } \\
\text { sessment (detection bias) } \\
\begin{array}{l}\text { All outcomes } \\
\text { L }\end{array}\end{array}$ & Low risk & "The assessors were blinded during the analysis." \\
\hline
\end{tabular}

Incomplete outcome data Unclear risk (attrition bias)

All outcomes
Gp A - Forsus Fatigue Resistance Device (FFRD) recruited 16, analysed 16 (loss $0 \%)$

Gp B - Forsus Fatigue Resistance Device with mini-implant (FMI) recruited 15, analysed 15 (loss 0\%)

Gp C - control/no intervention recruited 15, analysed 12 (loss 20\%)

Reasons for discontinuation in control group:

"Two of the control patients wanted to start treatment immediately, and a third could not be reached after 3 months"

\begin{tabular}{lll}
\hline $\begin{array}{l}\text { Selective reporting (re- } \\
\text { porting bias) }\end{array}$ & Low risk & All variables reported \\
\hline Other bias & Unclear risk & The sample comprised 32 females. \\
\hline
\end{tabular}

\section{Florida 1998}

\begin{tabular}{ll}
\hline Methods & Location: University of Florida, USA \\
& Number of centres: 1 \\
& Recruitment period: not stated \\
& Funding source: funded by NIH (DE08715) \\
& Trial design: parallel group RCT over 10 years \\
\hline
\end{tabular}


Florida 1998 (Continued)

Participants
Inclusion criteria: third or fourth grade at school, at least bilateral $1 / 2$ cusp Class II molars or 1 side < $1 / 2$ cusp Class II if other side greater than $1 / 2$ cusp Class II. Fully erupted permanent first molars, emergence of not more than 3 permanent canines or premolars and positive overbite and overjet

Exclusion criteria: not willing to undergo orthodontic treatment or to be randomly allocated to treatment type. Poor general health, active dental or periodontal pathology

Age at baseline: mean 9.6 years

Screened child population (360) then referred to clinic for treatment

Number randomised: 325 randomised, 277 started treatment: 95, 100 and 82 in bionator, headgear and control respectively

Number evaluated: end of treatment phase (I) 79/95, 92/100, 78/82; end of retention phase 75/95, $85 / 100$ and 75/82; and end of follow-up (II) 70/95, 81/100, 74/82 in bionator, headgear and control groups respectively

\begin{tabular}{ll}
\hline Outcomes & (i) Overjet \\
& (ii) Skeletal discrepancy \\
(iii) Dental alignment measured with the PAR index
\end{tabular}

\begin{tabular}{ll}
\hline Notes & Duration of randomised treatment: 2 years initially \\
Sample size calculation not reported
\end{tabular}

\section{Risk of bias}

Bias Authors' judgement Support for judgement

Random sequence genera- High risk A stratified block randomisation procedure was used:

tion (selection bias)

"Subjects initially were selected in blocks of six and randomized to the treatment protocols. This procedure of assigning subjects to groups only after a block had filled was modified in year 3 , after we recognised slow entry rate and many partially filled blocks ( $23 \%$ of the sample) were randomized to groups."

\begin{tabular}{lll}
\hline $\begin{array}{l}\text { Allocation concealment } \\
\text { (selection bias) }\end{array}$ & Unclear risk & Not described \\
\hline $\begin{array}{l}\text { Blinding of outcome as- } \\
\begin{array}{l}\text { sessment (detection bias) } \\
\text { All outcomes }\end{array}\end{array}$ & Low risk & $\begin{array}{l}\text { "All cephalometric radiographs were encoded by the staff assistant and then } \\
\text { decoded for analysis." }\end{array}$ \\
\hline $\begin{array}{l}\text { Incomplete outcome data } \\
\text { (attrition bias) }\end{array}$ & High risk & $\begin{array}{l}\text { Clear information on withdrawals. Dropouts: 24\%. Number of dropouts ap- } \\
\text { proximately equal in each group but rate of withdrawal was significantly high- } \\
\text { er for non-whites }\end{array}$ \\
\hline $\begin{array}{l}\text { Selective reporting (re- } \\
\text { porting bias) }\end{array}$ & Low risk & All variables reported \\
\hline
\end{tabular}

Orthodontic treatment for prominent upper front teeth (Class II malocclusion) in children and adolescents (Review) Copyright @ 2018 The Cochrane Collaboration. Published by John Wiley \& Sons, Ltd. 
Florida 1998 (Continued)

Other bias Low risk No other sources of bias identified

Ghafari 1998

Methods
Location: The University of Pennsylvania, USA
Recruitment period: not stated
Funding source: this study was supported by grants RO1-DE08722 and RR-00040 (NIH)
Trial design: parallel group RCT
Inclusion criteria: Class II, Division 1 malocclusion associated with bilateral distocclusion (unilateral
Class I excluded) and a minimum ANB angle of $4.5^{\circ}$; between 7 and $12.5 / 13$ years of age; no prior ortho-
dontic treatment; and expected residential stability of 3 years
Exclusion criteria: children with systemic, mental, behavioural, bleeding, and craniofacial disorders
were excluded. If siblings presented with the same malocclusion, only 1 of them was recruited because
they share in both the genetic background and environment
Age at baseline: chronological age range 7 years 2 months to 13 years 4 months. Skeletal age range at
baseline 5 years 9 months to 13 years 9 months and was basis of grouping participants into early $(<10$
years for girls and $<10.5$ years for boys) and late childhood
Number randomised: 84
Number evaluated: 63

Interventions

Gp A ( $n=35 / 41)$ : headgear - straight pull headgear inserted into the buccal tubes of bands cemented on permanent maxillary front molars

Gp B ( $n=28 / 43)$ : Frankel function regulator type II to be worn at least 16 hours per day

\begin{tabular}{ll}
\hline Outcomes & Skeletal measurements from cephalograms, occlusal changes \\
\hline Notes & Duration of randomised treatment: 2 years \\
& Sample size calculation: not specified \\
\hline
\end{tabular}

\section{Risk of bias}

\begin{tabular}{lll}
\hline Bias & Authors' judgement & Support for judgement \\
\hline $\begin{array}{l}\text { Random sequence genera- } \\
\text { tion (selection bias) }\end{array}$ & Unclear risk & $\begin{array}{l}\text { Randomised. "Within each severity group, the children were assigned at ran- } \\
\text { dom to treatment with either a headgear }(n=41) \text { or a Frankel FR ( } n=43) . "\end{array}$ \\
& Sequence generation method not described \\
\hline $\begin{array}{l}\text { Allocation concealment } \\
\text { (selection bias) }\end{array}$ & Unclear risk & Not described \\
\hline $\begin{array}{l}\text { Blinding of outcome as- } \\
\text { sessment (detection bias) } \\
\text { All outcomes }\end{array}$ & Unclear risk & Not described \\
\hline $\begin{array}{l}\text { Incomplete outcome data } \\
\text { (attrition bias) }\end{array}$ & High risk & $\begin{array}{l}\text { "Non cooperative children were those patients who, at some point in time, re- } \\
\text { fused to receive treatment, despite all efforts to retain them. The largest per- }\end{array}$ \\
\hline
\end{tabular}

Orthodontic treatment for prominent upper front teeth (Class II malocclusion) in children and adolescents (Review) 
Ghafari 1998 (Continued) All outcomes centage of these children were girls who wore the Fränkel regulator (42\%); by contrast, the smallest number discontinued were girls in the headgear group $(5 \%)$. The difference between these two groups of girls was statistically significant $(P<0.05)$. The percentages of boys lost to the study were similar in the headgear (24\%) and FR (25\%) groups."

Dropouts in headgear 6/41 (15\%), Frankel 15/43 (35\%). This statistically significant difference between groups is likely to introduce bias.
Selective reporting (re- Low risk $\quad$ All variables reported porting bias)
No other sources of bias identified

Complete set of data not reported. Data for only 26/84 participants reported

Jamilian 2011

\begin{tabular}{|c|c|}
\hline \multirow[t]{5}{*}{ Methods } & Location: University of Islamic Azad and Shahid Beheshti, Tehran, Iran \\
\hline & Number of centres: not specified \\
\hline & Recruitment period: not stated \\
\hline & Funding source: not stated \\
\hline & Trial design: parallel group RCT \\
\hline \multirow[t]{4}{*}{ Participants } & $\begin{array}{l}\text { Inclusion criteria: ANB }>4^{\circ}, \mathrm{SNB}<78^{\circ} \text { degrees, overjet } \geq 5 \mathrm{~mm} \text { at the start of treatment, no syndromic } \\
\text { or medically compromised patients, no previous surgical intervention, no use of other appliances be- } \\
\text { fore or during the period of functional treatment, a normal mandibular growth pattern: neither hori- } \\
\text { zontal nor vertical, no skeletal asymmetry }\end{array}$ \\
\hline & Age at baseline: R-appliance group 10.5 (SD 0.7) years and Twin Block group 11.3 (SD 1.3) years \\
\hline & Number randomised: 55 \\
\hline & Number evaluated: 55 (no dropouts) \\
\hline \multirow[t]{2}{*}{ Interventions } & Gp A ( $n=30)$ : R-appliance - Tooth- and tissue-born functional appliance worn full time \\
\hline & Gp B ( $n=25)$ : Twin Block appliance with upper labial bow worn full time \\
\hline Outcomes & Skeletal measurements from cephalograms, occlusal changes \\
\hline \multirow[t]{2}{*}{ Notes } & $\begin{array}{l}\text { Duration of randomised treatment: R-appliance } 16.2 \text { months (SD 0.3) months, Twin Block appliance } \\
16.1 \text { (SD 1.4) months }\end{array}$ \\
\hline & Sample size calculation: not specified \\
\hline
\end{tabular}

\section{Risk of bias}

\begin{tabular}{lll}
\hline Bias & Authors' judgement & Support for judgement \\
\hline $\begin{array}{l}\text { Random sequence genera- } \\
\text { tion (selection bias) }\end{array}$ & Low risk & $\begin{array}{l}\text { Randomised. "...patients were randomly divided to two groups using random } \\
\text { number tables" (unpublished data) }\end{array}$ \\
\hline $\begin{array}{l}\text { Allocation concealment } \\
\text { (selection bias) }\end{array}$ & Unclear risk & $\begin{array}{l}\text { Allocation concealment not clearly described. "Specific codes were assigned } \\
\text { to each patient for their concealment" (unpublished data) }\end{array}$ \\
\hline \hline
\end{tabular}


Jamilian 2011 (Continued)

Blinding of outcome as- Low risk Outcome assessors were blinded (unpublished data). However, the method of sessment (detection bias) blinding was not described.

All outcomes

\begin{tabular}{lll}
$\begin{array}{l}\text { Incomplete outcome data } \\
\text { (attrition bias) } \\
\text { All outcomes }\end{array}$ & Low risk & No dropouts \\
\hline $\begin{array}{l}\text { Selective reporting (re- } \\
\text { porting bias) }\end{array}$ & Low risk & All variables reported \\
\hline Other bias & Low risk & No other bias detected \\
\hline
\end{tabular}

\section{Jin 2015}

\begin{tabular}{|c|c|}
\hline \multirow[t]{5}{*}{ Methods } & Location: Department of Orthodontics, Shenyang Stomatological Hospital, China \\
\hline & Number of centres: not specified \\
\hline & Recruitment period: not stated \\
\hline & Funding source: not stated \\
\hline & Trial design: parallel group RCT \\
\hline \multirow[t]{4}{*}{ Participants } & $\begin{array}{l}\text { Inclusion criteria: dissolution, slightly dentition crowding, maxillary protrusion, mandibular retrusion, } \\
\text { ANB }>5^{\circ} \text {, low angle or medium mandibular plane angle. }\end{array}$ \\
\hline & Age at baseline: straight wire appliance 12.34 years and Twin Block group 12.05 years \\
\hline & Number randomised: 30 \\
\hline & Number evaluated: 30 (no dropouts) \\
\hline \multirow[t]{2}{*}{ Interventions } & Gp A ( $n=15)$ : straight wire appliance \\
\hline & Gp B $(n=15):$ Twin Block appliance \\
\hline Outcomes & Skeletal and soft tissues measurements from cephalograms \\
\hline \multirow[t]{2}{*}{ Notes } & Duration of randomised treatment: from 2006 to 2008 \\
\hline & Sample size calculation: not specified \\
\hline
\end{tabular}

\section{Risk of bias}

\begin{tabular}{lll}
\hline Bias & Authors' judgement & Support for judgement \\
\hline $\begin{array}{l}\text { Random sequence genera- } \\
\text { tion (selection bias) }\end{array}$ & Low risk & $\begin{array}{l}\text { Randomised. "30 patients were divided into 2 groups according to the random } \\
\text { number table method (15 patients per group)" }\end{array}$ \\
\hline $\begin{array}{l}\text { Allocation concealment } \\
\text { (selection bias) }\end{array}$ & Unclear risk & Not described \\
\hline $\begin{array}{l}\text { Blinding of outcome as- } \\
\text { sessment (detection bias) } \\
\text { All outcomes }\end{array}$ & Unclear risk & Outcome assessors blinding not described \\
\hline
\end{tabular}


Jin 2015 (Continued)

Incomplete outcome data Low risk No dropouts
(attrition bias)

All outcomes

\begin{tabular}{lll}
\hline $\begin{array}{l}\text { Selective reporting (re- } \\
\text { porting bias) }\end{array}$ & Low risk & All variables reported \\
\hline Other bias & Low risk & No other bias detected \\
\hline
\end{tabular}

Lee 2007

\begin{tabular}{|c|c|}
\hline \multirow[t]{5}{*}{ Methods } & Location: London, UK \\
\hline & Number of centres: 1 \\
\hline & Recruitment period: not stated \\
\hline & Funding source: not stated \\
\hline & Trial design: parallel group RCT \\
\hline \multirow[t]{5}{*}{ Participants } & $\begin{array}{l}\text { Inclusion criteria: Class II Division } 1 \text { malocclusion, minimum overjet of } 7 \mathrm{~mm} \text {, mandibular retrognathia } \\
\text { contributing to the Skeletal II pattern as assessed clinically. Male Caucasians aged } 11 \text { to } 14 \text { years and } \\
\text { female Caucasians aged } 10 \text { to } 13 \text { years }\end{array}$ \\
\hline & Exclusion criteria: previous orthodontic treatment or extraction of permanent teeth \\
\hline & Age at baseline: 28 males 12 to 14.7 years, 34 females 10.6 to 13.7 years \\
\hline & Number randomised: 62 \\
\hline & Number evaluated: 56 \\
\hline \multirow[t]{2}{*}{ Interventions } & $\begin{array}{l}\text { Gp A }(n=31) \text { : Twin Block without upper labial bow. Blocks designed to interlock at inclination of ap- } \\
\text { proximately } 70^{\circ}\end{array}$ \\
\hline & Gp B $(n=31):$ Dynamax functional appliance \\
\hline Outcomes & $\begin{array}{l}\text { Skeletal discrepancy measured by cephalometric radiographs, soft tissue changes measured by optical } \\
\text { surface laser scanner }\end{array}$ \\
\hline \multirow[t]{3}{*}{ Notes } & Duration of randomised treatment: 9 months \\
\hline & $\begin{array}{l}\text { Sample size calculation: "The recruitment of } 62 \text { subjects allowed the creation of } 31 \text { matched pairs who } \\
\text { were subsequently randomly allocated. This was the minimum number of patients required to satisfy } \\
\text { the statistical power calculation." }\end{array}$ \\
\hline & Email sent to authors requesting clarification of sequence generation procedure. No reply to date \\
\hline
\end{tabular}

\section{Risk of bias}

\begin{tabular}{lll}
\hline Bias & Authors' judgement & Support for judgement \\
\hline $\begin{array}{l}\text { Random sequence genera- } \\
\text { tion (selection bias) }\end{array}$ & Unclear risk & $\begin{array}{l}\text { "...patients were matched for gender and age and then randomly allocated to } \\
\text { an appliance group by a non-clinician" }\end{array}$ \\
& & Method of sequence generation not reported
\end{tabular}


Lee 2007 (Continued)

\begin{tabular}{lll}
$\begin{array}{l}\text { Allocation concealment } \\
\text { (selection bias) }\end{array}$ & Unclear risk & Not described \\
\hline $\begin{array}{l}\text { Blinding of outcome as- } \\
\text { sessment (detection bias) }\end{array}$ & Unclear risk & Not specified \\
All outcomes & &
\end{tabular}

\begin{tabular}{ll}
\hline $\begin{array}{l}\text { Incomplete outcome data } \\
\text { (attrition bias) }\end{array}$ & $\begin{array}{l}6 \text { participants failed to complete trial. } 3 \text { in Twin Block group and } 3 \text { in Dynamax } \\
\text { group. Reasons not specified }\end{array}$ \\
\hline
\end{tabular}

\begin{tabular}{lll}
\hline $\begin{array}{l}\text { Selective reporting (re- } \\
\text { porting bias) }\end{array}$ & Low risk & Uncleariables reported \\
\hline Other bias & $\begin{array}{l}\text { "A higher percentage of subjects were found to present with appliance break- } \\
\text { ages in the Dynamax group (55\%) than in the Twin Block group (35\%)." }\end{array}$ \\
\hline
\end{tabular}

London 1998

\begin{tabular}{ll}
\hline Methods & Location: London, UK \\
& Number of centres: 1 \\
& Recruitment period: not stated \\
& Funding source: not stated \\
& Trial design: parallel group RCT (3 interventions randomly allocated) \\
\hline
\end{tabular}

Participants Inclusion criteria: children aged 8 to 15 years old with Class II Division 1 malocclusion and an overjet
greater than $7 \mathrm{~mm}$. Moderate Skeletal II base relationship with mandibular retrognathia

Exclusion criteria: previous orthodontic therapy or extraction of permanent teeth, or significant adverse medical history

Age at baseline: mean 12 years

Number randomised: 58 (18, 21, 19 to Gps A, B and C respectively)

Number evaluated: 47 (13, 18, 16 from Gps A, B and C respectively)

\begin{tabular}{ll}
\hline Interventions & Gp A ( $=13)$ : Bass appliance \\
& Gp B $(\mathrm{n}=18)$ : Bionator appliance \\
& Gp C $(\mathrm{n}=16)$ : Twin Block appliance \\
\hline Outcomes & (i) Overjet \\
& (ii) Skeletal discrepancy - ANB method unclear \\
& (iii) Soft tissue variables \\
\hline Notes & Duration of randomised treatment: 9 months \\
& Sample size calculation: not reported. Numbers of participants completing trial are very small and trial \\
& likely to be underpowered
\end{tabular}

\section{Risk of bias}

Orthodontic treatment for prominent upper front teeth (Class II malocclusion) in children and adolescents (Review) 
London 1998 (Continued)

\section{Bias Authors' judgement Support for judgement}

Random sequence genera- Unclear risk
tion (selection bias)

Randomised to treatment groups and control group not randomised

Method of sequence generation not described

\begin{tabular}{lll}
\hline $\begin{array}{l}\text { Allocation concealment } \\
\text { (selection bias) }\end{array}$ & Unclear risk & Unclear \\
\hline $\begin{array}{l}\text { Blinding of outcome as- } \\
\text { sessment (detection bias) }\end{array}$ & Unclear risk & \\
All outcomes & & \\
\hline
\end{tabular}

\begin{tabular}{|c|c|c|}
\hline $\begin{array}{l}\text { Incomplete outcome data } \\
\text { (attrition bias) } \\
\text { All outcomes }\end{array}$ & High risk & $\begin{array}{l}\text { Clear information on withdrawals. Dropouts: } 19 \% .58 \text { enrolled and } 47 \text { complet- } \\
\text { ed } \\
\text { Dropouts } 5(27 \%), 3(15 \%) \text { and } 3(17 \%) \text { in Bass, Bionator and Twin Block group } \\
\text { respectively. Reasons not reported }\end{array}$ \\
\hline $\begin{array}{l}\text { Selective reporting (re- } \\
\text { porting bias) }\end{array}$ & Low risk & All variables reported \\
\hline Other bias & Unclear risk & $\begin{array}{l}\text { Differences in age at baseline between randomised groups. Not statistically } \\
\text { significant but this may be due to small numbers in each group }\end{array}$ \\
\hline
\end{tabular}

Mao 1997

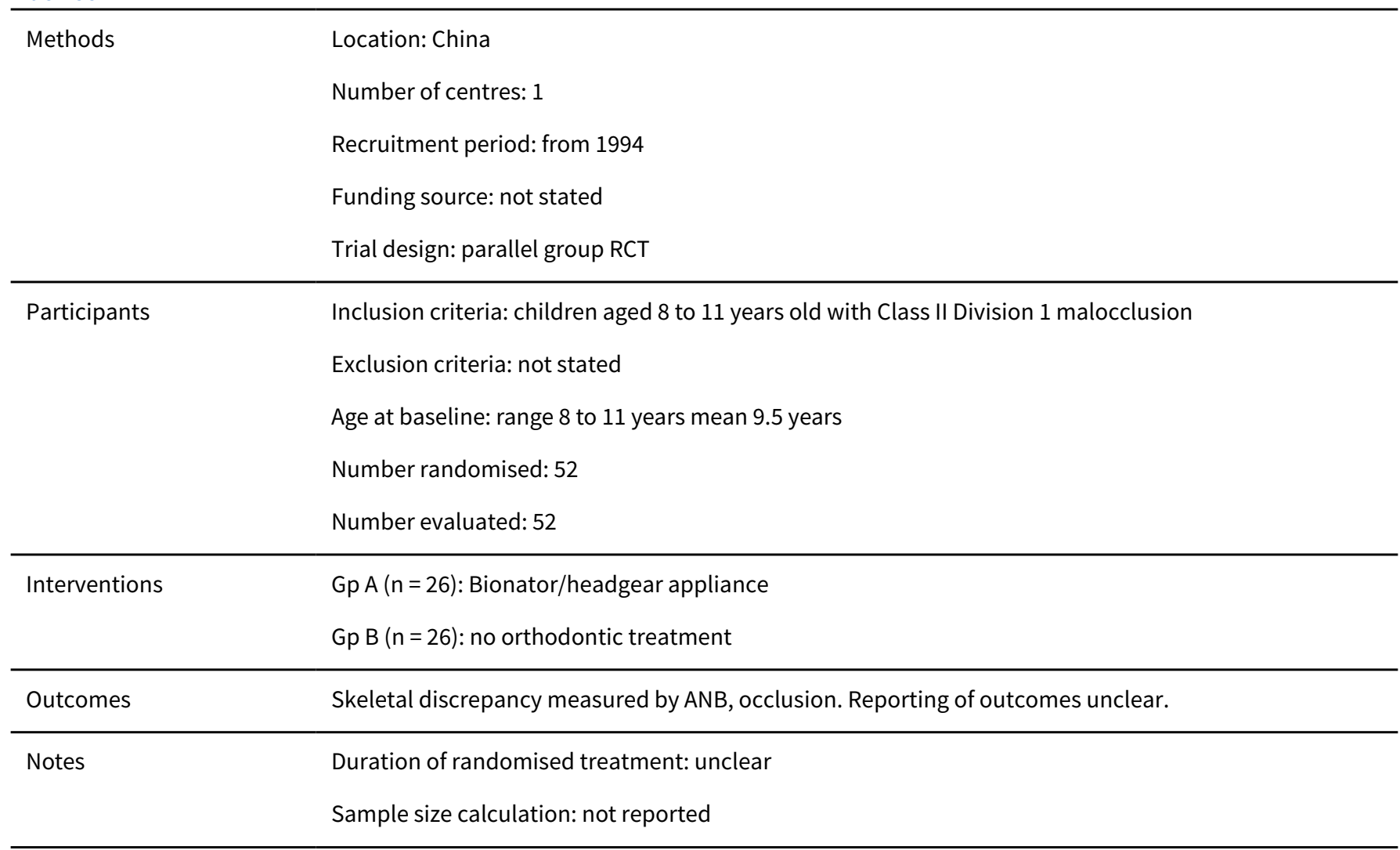

\section{Risk of bias}

Orthodontic treatment for prominent upper front teeth (Class II malocclusion) in children and adolescents (Review) 
Mao 1997 (Continued)

\section{Bias Authors'judgement Support for judgement}

Random sequence genera- Unclear risk tion (selection bias)

Randomly allocated. "The 52 children were randomly divided into two groups, treated group ( $n=26,18$ males and 8 females) and untreated group $(n=26,9$ males and 17 females)."

Method of sequence generation not specified

\begin{tabular}{lll}
\hline $\begin{array}{l}\text { Allocation concealment } \\
\text { (selection bias) }\end{array}$ & Unclear risk & Not reported \\
\hline $\begin{array}{l}\text { Blinding of outcome as- } \\
\text { sessment (detection bias) }\end{array}$ & Unclear risk & Unclear on blinding \\
All outcomes & & \\
\hline
\end{tabular}

Incomplete outcome data Unclear risk Dropouts not specified

(attrition bias)

Dropouts not specified

All outcomes

\begin{tabular}{lll}
\hline $\begin{array}{l}\text { Selective reporting (re- } \\
\text { porting bias) }\end{array}$ & Unclear risk & Reporting of data not clear \\
\hline Other bias & High risk & $\begin{array}{l}\text { Data reported unclear. Groups very different at baseline (Bionator group 18 } \\
\text { males, } 6 \text { females and untreated group 9 males and 17 females) }\end{array}$ \\
\hline
\end{tabular}

Martina 2013

$\begin{array}{ll}\text { Methods } & \text { Location: Italy } \\ & \text { Number of centres: } 1 \\ & \text { Recruitment period: April } 2006 \text { to June } 2007 \\ & \text { Funding source: Italian Ministry of University and Research } \\ & \text { Trial design: parallel group RCT }\end{array}$

Participants Inclusion criteria: "Full class II molar relationships, overjet $\geq 6 \mathrm{~mm}$, an age range of $10-13$ years for boys and of 9-12 years for girls".

Exclusion criteria: "Cervical vertebral maturation stage (CVMS) $<2$ or $>3$ (25), lack of parent's willingness to sign an informed consent form, sella-nasion to mandibular plane (Me-Go) angle equal to or greater than the normal value plus a standard deviation, periodontal diseases, orofacial inflammatory conditions, tooth agenesis, congenital syndromes, and previous orthodontic treatment.

Age at baseline: range 10 to 13 years for boys and 9 to 12 years for girls

Number randomised: 61

Number evaluated: 46

Interventions
Gp A $(n=23)$ : Sander Bite jump appliance
Gp $(n=23)$ : no orthodontic treatment

Outcomes Dentoalveolar, sagittal, and vertical changes assessed trough cephalometric analysis

Notes Duration of randomised treatment: 18 months (BJA) and 12 months (control group)


Martina 2013 (Continued)

Sample size calculation: "The determination of sample size was based upon previous estimates of changes in mandibular length (Pg/OLp) during growth. By setting type I error at 0.05 and type II error at 0.20 ( $80 \%$ power), it was found that at least 19 patients per group were needed to detect an increase in mandibular length $\geq 2.0 \mathrm{~mm}$.

\title{
Risk of bias
}

Bias Authors' judgement Support for judgement

Random sequence genera- Low risk tion (selection bias)

"Enrolled patients were allocated to either a treatment (BJA) or control (CTR) group by balanced block randomization using gender as a stratifying factor. $\mathrm{A}$ custom-made Java script was used to generate the randomization procedure by a single investigator (SP) that was not involved in the clinical management of patients and control subjects."

$\begin{array}{ll}\begin{array}{l}\text { Allocation concealment } \quad \text { Low risk } \\ \text { (selection bias) }\end{array} & \text { "The randomization sequence was carefully concealed to the other investiga- } \\ & \text { tors and was disclosed immediately after obtaining written informed consent. } \\ & \text { Patients allocated to the BJA group were treated with the BJA, whereas pa- } \\ & \text { tients allocated to the CTR group did not receive any treatment and acted as } \\ \text { passive controls." }\end{array}$

Blinding of outcome as- Low risk "A single operator (IC), who was blinded to patient allocation (i.e. the alloca-
sessment (detection bias) tion was masked to him in the dataset) performed the statistical analyses." All outcomes

Incomplete outcome data High risk
(attrition bias)

All outcomes

\author{
Gp A - BJA recruited 31, analysed 23 (loss 25\%) \\ Gp B - control recruited 30, analysed 23 (loss 23\%) \\ Reasons for discontinuation:
}

BJA group - did not receive allocated intervention ( $n=6 ; 4$ not willing to go further in the trial, 2 transferred); lost to follow-up $(n=2)$

Control group - lost to follow-up $(n=7)$

\begin{tabular}{lll}
\hline $\begin{array}{l}\text { Selective reporting (re- } \\
\text { porting bias) }\end{array}$ & Low risk & All variables reported \\
\hline Other bias & Low risk & No other bias found \\
\hline
\end{tabular}

New Zealand 2000

\begin{tabular}{ll}
\hline Methods & Location: New Zealand \\
& Number of centres: 1 \\
& Funding source: Medical Research Council of New Zealand \\
& Trial design: parallel group RCT (3 groups) \\
\hline
\end{tabular}

Inclusion criteria: children in clinic with Class II Division 1 malocclusion
Exclusion criteria: none specified
Age at baseline: range 10 to 13 years, mean age (boys) 11.28 (SD 0.91) and girls 11.89 (SD 0.68$)$
Number randomised: 50 (18 'triads')


New Zealand 2000 (Continued)

Number evaluated: 42 (12, 13, 17 in Gps A, B and C respectively)

\begin{tabular}{l}
\hline Gp A: Harvold Activator functional appliance \\
Gp B: Frankel functional regulator (FR-2) \\
Appliances to be worn for 14 hours per day (times of wearing slowly increased over first month of treat- \\
ment) \\
Gp C: untreated control group
\end{tabular}

\begin{tabular}{ll}
\hline Outcomes & (i) Change in skeletal pattern; (ii) Change in overjet; (iii) PAR score \\
& ANB was not reported \\
\hline Notes & Duration of randomised treatment: 18 months \\
& $\begin{array}{l}\text { Sample size calculation: "The study was large enough to have a power of about } 80 \% \text { of detecting a } 1 \\
\text { standard deviation difference with } \mathrm{P}<0.05 . "\end{array}$
\end{tabular}

\section{Risk of bias}

\begin{tabular}{|c|c|c|}
\hline Bias & Authors' judgement & Support for judgement \\
\hline \multirow[t]{2}{*}{$\begin{array}{l}\text { Random sequence genera- } \\
\text { tion (selection bias) }\end{array}$} & Unclear risk & $\begin{array}{l}\text { "...were matched in triads according to age and sex and randomly assigned to } \\
\text { either the control group }(\mathrm{C}) \text {, the Frankel function regulator group (FFR), or the } \\
\text { Harvold activator group (HA)" }\end{array}$ \\
\hline & & Method of sequence generation not described \\
\hline $\begin{array}{l}\text { Allocation concealment } \\
\text { (selection bias) }\end{array}$ & High risk & Not described. Allocation likely to be predictable within each group of 3 \\
\hline $\begin{array}{l}\text { Blinding of outcome as- } \\
\text { sessment (detection bias) } \\
\text { All outcomes }\end{array}$ & Unclear risk & Not reported \\
\hline Incomplete outcome data & High risk & 50 enrolled and 42 completed. Dropouts: $16 \%$ \\
\hline All outcomes & & $\begin{array}{l}\text { Reasons for dropouts reported "Six children were removed from the study be- } \\
\text { cause they either repeatedly failed appointments or refused to wear the appli- } \\
\text { ance as instructed. Two children moved to another region." All dropouts from } \\
\text { the } 2 \text { treatment groups. } 5 / 17(29 \%) \text { from Activator group and 3/16 (19\%) from } \\
\text { Frankel group. }\end{array}$ \\
\hline $\begin{array}{l}\text { Selective reporting (re- } \\
\text { porting bias) }\end{array}$ & Low risk & All variables reported \\
\hline Other bias & Low risk & Groups similar at baseline for age group and gender \\
\hline
\end{tabular}

North Carolina 2004

\begin{tabular}{ll}
\hline Methods & Location: USA \\
& Number of centres: 1 \\
& Recruitment period: August 1988 to November 1993 \\
& Funding source: grants from NIH, and Orthodontic Fund, Dental Foundation of North Carolina \\
\hline
\end{tabular}


North Carolina 2004 (Continued)

Trial design: parallel group RCT with 2 treatment phases

Participants Inclusion criteria: children with mixed dentition, with all permanent teeth developing, with growth potential throughout phase 1 of treatment. Overjet $>7 \mathrm{~mm}$, all incisors erupted, second molars not erupted

Exclusion criteria: clinically obvious facial asymmetry, cleft or syndrome patients, more than 2 standard deviations from normal vertical proportionality, and those with prior orthodontic treatment

Age group: mean 9.4 years (SD 1.0)

Screened child population (2164) then referred to clinic for treatment

Number randomised: 192 randomised, 175 started treatment

Number evaluated: 53, 52, 61 at the end of phase 1, and 39, 47, 51 at the end of phase 2 for bionator, headgear and control groups respectively

Gp A ( $n=53)$ : functional appliance - modified bionator with the bite taken with $4 \mathrm{~mm}$ to $6 \mathrm{~mm}$ of protrusion and minimal vertical opening. Reactivation of appliance when necessary was by construction of a new appliance

Gp B ( $n=52)$ : headgear - combination headgear with supershort outer bow, adjusted to deliver 8 to 10 ounces to the headcap, with neck strap force just sufficient to prevent buccal flaring of upper molars

All appliances delivered within 1 month of patient's initial records being taken

Gp C ( $n=61)$ : control (observation only)

\begin{tabular}{ll} 
Outcomes & Skeletal growth changes; maxilla, mandible, skeletal relationship, dental relationship \\
\hline Notes & Duration of intervention: phase $1-15$ months; and phase $2-25.5,30.1$ and 34.5 for functional, head- \\
gear and control group & \\
Frequency of treatment visits: every 6 to 8 weeks for active treatment groups and every 6 months for \\
control group \\
Sample size calculation: sample size of 40 per group was calculated as necessary to detect a mean dif- \\
ference between any 2 groups equivalent to the doubling in annualised change of SNPg (with alpha = \\
0.01 and power $=0.90)$ \\
Patients were re-randomised at the end of phase 2 for different clinicians.
\end{tabular}

\section{Risk of bias}

\begin{tabular}{lll}
\hline Bias & Authors' judgement & Support for judgement \\
\hline $\begin{array}{l}\text { Random sequence genera- } \\
\text { tion (selection bias) }\end{array}$ & Low risk & $\begin{array}{l}\text { "Randomization was performed within gender in blocks of six patients with } \\
\text { Proc Plan in SAS" }\end{array}$ \\
\hline $\begin{array}{l}\text { Allocation concealment } \\
\text { (selection bias) }\end{array}$ & Unclear risk & Not described \\
\hline
\end{tabular}

Blinding of outcome assessment (detection bias) All outcomes

\section{High risk}

Because the molar bands were not removed at the end of phase 1 , the technician was not masked as to the treatment groups of these participants.

\begin{tabular}{|c|c|c|}
\hline $\begin{array}{l}\text { Incomplete outcome data } \\
\text { (attrition bias) }\end{array}$ & Unclear risk & Number of participants randomised in different groups not reported \\
\hline All outcomes & & 192 randomised, 175 started, 166 finished phase 1 and 137 finished phase 2 \\
\hline
\end{tabular}


North Carolina 2004 (Continued)

Dropout rate of $13.5 \%$ (low risk) for phase 1 and $28.6 \%$ (high risk) for phase 2 .

Reasons for dropouts reported, but not for each treatment group

\begin{tabular}{lll}
\hline $\begin{array}{l}\text { Selective reporting (re- } \\
\text { porting bias) }\end{array}$ & Low risk & All variables reported \\
\hline Other bias & Low risk & No other bias found \\
\hline
\end{tabular}

\section{Showkatbakhsh 2011}

\begin{tabular}{ll}
\hline Methods & Location: Tehran, Iran \\
& Number of centres: not specified \\
& Recruitment period: not stated \\
& Funding source: not stated \\
& Trial design: parallel group RCT
\end{tabular}

\section{Participants}

Inclusion criteria: $\mathrm{ANB}>4^{\circ}, \mathrm{SNB}<78^{\circ}$, overjet $>5 \mathrm{~mm}$ in the initial lateral cephalogram. No syndromic or medically compromised patients, no surgical intervention, no use of other appliances before or during the period of functional treatment, normal growth pattern of the mandible (MP-SN), symmetric relationship between maxilla and mandible

Exclusion criteria: not stated

Age at baseline: R-appliance mean age 10.4 (SD 0.8). Anterior Inclined Bite Plate (AIBP) 9 (SD 1.2) years

Number randomised: 50 randomised, 50 started treatment

Number evaluated: 50 at the end of functional phase (no dropouts) (unpublished data)

$\begin{array}{ll}\text { Interventions } & \text { Gp A }(n=25): \text { R-appliance } \\ \text { Gp B }(n=25): \text { Anterior Inclined Bite Plate (AIBP) }\end{array}$

Outcomes

Skeletal growth changes; maxilla, mandible, skeletal relationship reported. Dental measurements were not reported

Notes

Duration of intervention: Gp A (R-appliance): 11 (SD 2) months. Gp B: 9 (SD 1.2) months

Sample size calculation: not specified

\section{Risk of bias}

\begin{tabular}{lll}
\hline Bias & Authors' judgement & Support for judgement \\
\hline $\begin{array}{l}\text { Random sequence genera- } \\
\text { tion (selection bias) }\end{array}$ & Low risk & $\begin{array}{l}\text { "Patients were randomly assigned to two groups using standardised random } \\
\text { number table" }\end{array}$ \\
\hline $\begin{array}{l}\text { Allocation concealment } \\
\text { (selection bias) }\end{array}$ & Unclear risk & Not specified \\
\hline $\begin{array}{l}\text { Blinding of outcome as- } \\
\text { sessment (detection bias) } \\
\text { All outcomes }\end{array}$ & Unclear risk & Not stated \\
\hline
\end{tabular}


Showkatbakhsh 2011 (Continued)

\begin{tabular}{lll}
$\begin{array}{l}\text { Incomplete outcome data } \\
\text { (attrition bias) } \\
\text { All outcomes }\end{array}$ & Low risk & No dropouts \\
\hline $\begin{array}{l}\text { Selective reporting (re- } \\
\text { porting bias) }\end{array}$ & Unclear risk & $\begin{array}{l}\text { Only skeletal measurements reported. No linear dental measurements report- } \\
\text { ed }\end{array}$ \\
\hline Other bias & Low risk & No other bias detected \\
\hline
\end{tabular}

Thiruvenkatachari 2010

\begin{tabular}{|c|c|}
\hline \multirow[t]{5}{*}{ Methods } & Location: United Kingdom \\
\hline & Number of centres: 2 \\
\hline & Recruitment period: January 2008 to January 2009 \\
\hline & Funding source: not stated \\
\hline & Trial design: parallel group RCT \\
\hline \multirow[t]{5}{*}{ Participants } & Inclusion criteria: children aged 10 to 14 years with overjet greater than $6 \mathrm{~mm}$ \\
\hline & Exclusion criteria: craniofacial syndrome, previous orthodontic treatment or premolar extractions \\
\hline & Age group: not stated \\
\hline & Number randomised: 64 \\
\hline & Number evaluated: 64 \\
\hline \multirow[t]{3}{*}{ Interventions } & Gp A ( $n=32):$ Twin Block appliance \\
\hline & Gp B ( $n=32)$ : Dynamax appliance \\
\hline & $\begin{array}{l}\text { Participants were asked to wear appliances } 24 \text { hours per day except during contact sports and swim- } \\
\text { ming }\end{array}$ \\
\hline Outcomes & $\begin{array}{l}\text { Skeletal measurement from cephalometric radiographs. Clinical measure of overjet. Appliance break- } \\
\text { ages and adverse events }\end{array}$ \\
\hline \multirow[t]{2}{*}{ Notes } & Duration of randomised treatment: Trial stopped early based on planned interim analysis \\
\hline & $\begin{array}{l}\text { Sample size calculation: "The sample size calculation was based on the data from a previous investi- } \\
\text { gation into the effectiveness of the Twin-block and Herbst appliances. We considered that a minimum } \\
\text { clinically meaningful difference in treatment duration between } 2 \text { competing treatments was } 4 \text { months } \\
\text { (common SD 4.61). For a trial with a power of } 80 \% \text { and an alpha of } 0.05 \text {, a sample of } 32 \text { patients in each } \\
\text { group was required, with an estimated noncompliance rate of } 30 \% \text {." }\end{array}$ \\
\hline
\end{tabular}

\section{Risk of bias}

\section{Bias \\ Authors' judgement Support for judgement}

Random sequence genera- Low risk tion (selection bias)
Central randomisation allocation and allocation by a computer using minimisation software

"Patients were then allocated by using minimization to one of the treatments by using MINIM software, with sex as a prognostic factor." 
Thiruvenkatachari 2010 (Continued)

$\begin{array}{ll}\begin{array}{l}\text { Allocation concealment } \\ \text { (selection bias) }\end{array} & \text { Low risk }\end{array}$

$\begin{array}{ll}\text { Blinding of outcome as- } & \text { Unclear risk }\end{array}$

sessment (detection bias)

All outcomes

DMC assessors and trial statistician blinded to treatment allocation

\begin{tabular}{|c|c|c|}
\hline $\begin{array}{l}\text { Incomplete outcome data } \\
\text { (attrition bias) } \\
\text { All outcomes }\end{array}$ & Unclear risk & $\begin{array}{l}\text { Trial stopped early due to adverse events and clinical improvement } \\
7 / 32 \text { Twin Block participants and 3/32 Dynamax participants dropped out of } \\
\text { the trial }\end{array}$ \\
\hline & & $\begin{array}{l}\text { Reasons for dropouts: } 9 \text { failed to attend the follow-up appointment and } 1 \text { re- } \\
\text { quired headgear }\end{array}$ \\
\hline
\end{tabular}

\begin{tabular}{lll}
\hline $\begin{array}{l}\text { Selective reporting (re- } \\
\text { porting bias) }\end{array}$ & Low risk & $\begin{array}{l}\text { Not all outcome variables (cephalometric data) assessed due to premature } \\
\text { termination }\end{array}$ \\
\hline Other bias & High risk & Trial stopped early based on interim analysis \\
\hline
\end{tabular}

UK (11-14) 2003

\begin{tabular}{ll} 
Methods & Location: United Kingdom \\
& Number of centres: 13 centres \\
& Recruitment period: March 1997 to June 1998 \\
& Funding source: Medical Research Council (99410454) \\
& Trial design: parallel group RCT \\
\hline Inclusion criteria: children aged 11 to 14 with overjet greater than 7 mm, and second premolars erupted \\
Exclusion criteria: craniofacial syndrome \\
Age at baseline: Gp A mean 12.41 (95\% Cl 12.17 to 12.63), Gp B 12.74 (95\% Cl 12.48 to 12.99) \\
Number randomised: 215 \\
Number evaluated: 183
\end{tabular}

Gp A: Twin Block appliance
Gp B: Herbst appliance
Participants were requested to wear the appliances 24 hours per day except during contact sports or
swimming. Treatment with functional appliances was followed by treatment with fixed appliances if
necessary

Outcomes (i) Overjet

(ii) Skeletal discrepancy measured by Pancherz analysis

(iii) Dental alignment measured with the PAR index

(iv) Duration of treatment

\begin{tabular}{|c|c|}
\hline Notes & $\begin{array}{l}\text { Duration of intervention: as required to reduce overjet. } G p A=11.22 \text { (9.58 to } 12.86), G p B=5.81 \text { ( } 5.13 \text { to } \\
6.48 \text { ) }\end{array}$ \\
\hline
\end{tabular}


UK (11-14) 2003 (Continued)

Sample size calculation: "We based our sample size calculation for the number of patients necessary to achieve $80 \%$ power with an alpha of 0.05 on a clinically meaningful difference in peer assessment rating (PAR) scores of $15 \%$ between the study groups. The calculation showed that we needed to recruit 80 patients into each arm of the study to account for an estimated non-completion rate of $15 \%$."

\section{Risk of bias}

Bias Authors' judgement Support for judgement

Random sequence genera- Low risk tion (selection bias)

"...the patient was randomized to receive treatment with either a Twinblock or a Herbst appliance. ....At the beginning of the study, random number tables were used to prepare randomization lists, stratified by centre and sex into permuted blocks."

\begin{tabular}{ll}
\hline $\begin{array}{l}\text { Allocation concealment } \\
\text { (selection bias) }\end{array}$ & Low risk
\end{tabular}

\begin{tabular}{ll}
\hline $\begin{array}{l}\text { Blinding of outcome as- } \\
\text { sessment (detection bias) }\end{array}$ & Low risk
\end{tabular}$\quad \begin{aligned} & \text { "Cephalograms and study casts were both scored with the examiner unaware } \\
& \text { of the group to which the patient had been allocated." }\end{aligned}$

All outcomes

\begin{tabular}{ll}
\hline $\begin{array}{l}\text { Incomplete outcome data } \\
\text { (attrition bias) }\end{array}$ & High risk \\
All outcomes & $\begin{array}{l}215 \text { enrolled and } 183 \text { evaluated. 25/110 (23\%) lost in Twin Block group and } \\
7 / 105(7 \%) \text { in Herbst appliance group. Reasons for dropouts specified (unpub- } \\
\text { lished data). Dropouts significantly different between groups }\end{array}$ \\
& $\begin{array}{l}\text { Herbst group: } 5 \text { had problems with appliance and discontinued, } 1 \text { moved } \\
\text { away/lost to follow-up }\end{array}$ \\
& $\begin{array}{l}\text { Twin Block group: } 14 \text { had multiple DNAs and were discharged with no fol- } \\
\text { low-up records, } 5 \text { moved away/lost to follow-up, } 5 \text { refused to wear the appli- } \\
\text { ance, } 1 \text { fitted with wrong appliance }\end{array}$
\end{tabular}

\begin{tabular}{lll}
\hline $\begin{array}{l}\text { Selective reporting (re- } \\
\text { porting bias) }\end{array}$ & Low risk & All variables reported \\
\hline Other bias & Low risk & Groups appear similar at baseline \\
\hline
\end{tabular}

\begin{tabular}{|c|c|}
\hline \multirow[t]{5}{*}{ Methods } & Location: United Kingdom \\
\hline & Number of centres: 13 centres \\
\hline & Recruitment period: March 1997 to August 1999 \\
\hline & Funding source: Medical Research Council (G9410454) \\
\hline & Trial design: randomised parallel group trial \\
\hline
\end{tabular}

Participants

Inclusion criteria: children in the mixed dentition with overjet greater than $7 \mathrm{~mm}$, and willingness of the patient and a parent to participate in the study. Participants had to be in the mixed dentition with at least the permanent incisors and first molars erupted, but there was no age criterion

Exclusion criteria: craniofacial syndromes

Age at baseline: the average age was 9.7 (SD 0.98) years for the treatment group and 9.8 (SD 0.94) years for the control group.

Number randomised: 174 
UK (Mixed) 2009 (Continued)

Number evaluated: 127

Interventions $\quad$ Gp A: Twin Block early treatment: randomised 89, completed 67

Gp B: Twin Block delayed treatment: randomised 85, completed 73

Outcomes
(i) Overjet
(ii) Skeletal discrepancy measured by Pancherz analysis
(iii) Dental alignment measured with the PAR index
(iv) Sociopsychological effects of treatment

Notes Duration of intervention: 15 months

Sample size calculation: "This showed that the mean duration of treatment for patients who had later treatment after early treatment was 25 months (SD 11). It was decided that a meaningful difference between the treatment duration for children who did, or did not, receive early treatment was 6 months. To give a study a power of $80 \%$ and an alpha of 0.05 , the sample size needed to be 60 in each group."

\section{Risk of bias}

\begin{tabular}{|c|c|c|}
\hline Bias & Authors' judgement & Support for judgement \\
\hline $\begin{array}{l}\text { Random sequence genera- } \\
\text { tion (selection bias) }\end{array}$ & Low risk & $\begin{array}{l}\text { "The randomization was made at the start of the study with pre-prepared ran- } \\
\text { dom number tables with a block stratification on centre and sex." }\end{array}$ \\
\hline $\begin{array}{l}\text { Allocation concealment } \\
\text { (selection bias) }\end{array}$ & Low risk & $\begin{array}{l}\text { Randomisation carried out using a central telephone line and minimisation } \\
\text { software }\end{array}$ \\
\hline $\begin{array}{l}\text { Blinding of outcome as- } \\
\text { sessment (detection bias) } \\
\text { All outcomes }\end{array}$ & Low risk & $\begin{array}{l}\text { Assessor blinded to outcomes. "The cephalograms and the study casts were } \\
\text { scored with the examiner unaware of the patient's group." }\end{array}$ \\
\hline \multirow{4}{*}{$\begin{array}{l}\text { Incomplete outcome data } \\
\text { (attrition bias) } \\
\text { All outcomes }\end{array}$} & Low risk & $\begin{array}{l}\text { Clear information on withdrawals, but rates different in each group. 22/89 } \\
(25 \%) \text { in the Twin Block group and } 12 / 85(14 \%) \text { in the control group }\end{array}$ \\
\hline & & Reasons for exclusion specified (unpublished data) \\
\hline & & $\begin{array}{l}\text { Control group: } 4 \text { refused to consent for phase } 2 \text { treatment, } 1 \text { withdrew due to } \\
\text { illness, } 3 \text { had multiple DNAs with no final records, } 1 \text { moved away/lost contact, } \\
2 \text { had Twin Blocks fitted in phase } 1 \text { in error, } 1 \text { had sore mouth and required } \\
\text { treatment in phase } 1\end{array}$ \\
\hline & & $\begin{array}{l}\text { Treatment group: } 2 \text { moved away/lost contact, } 9 \text { had multiple DNA with no fol- } \\
\text { low-up records, } 4 \text { did not start as eligibility criteria was not met, } 5 \text { refused to } \\
\text { continue, } 1 \text { had poor oral health, } 1 \text { removed from study due to health prob- } \\
\text { lems }\end{array}$ \\
\hline $\begin{array}{l}\text { Selective reporting (re- } \\
\text { porting bias) }\end{array}$ & Low risk & All variables reported \\
\hline Other bias & Low risk & Groups appear similar at baseline \\
\hline
\end{tabular}

Yaqoob 2012

Methods Location: United Kingdom


Yaqoob 2012 (Continued)

Number of centres: 1 (Kent and Canterbury Hospital)

Recruitment period: not stated

Funding source: not stated

Trial design: parallel group RCT

\begin{tabular}{|c|c|}
\hline \multirow[t]{5}{*}{ Participants } & $\begin{array}{l}\text { Inclusion criteria: children aged } 10 \text { to } 14 \text { years with Class II Division } 1 \text { incisor relationship (British Stan- } \\
\text { dards Institute), overjet greater than } 6 \mathrm{~mm} \text {, molar relationship at least a half unit Angle Class II, white } \\
\text { ethnic origin }\end{array}$ \\
\hline & $\begin{array}{l}\text { Exclusion criteria: previous history of orthodontic therapy or permanent tooth extraction, no signifi- } \\
\text { cant or adverse medical history or craniofacial syndrome }\end{array}$ \\
\hline & $\begin{array}{l}\text { Age at baseline: mean Gp A } 12.5 \text { years (range } 10.5 \text { to } 13.5 \text { years), Gp B } 12.3 \text { years (range } 10.8 \text { to } 13.2 \\
\text { years) }\end{array}$ \\
\hline & Number randomised: 64 \\
\hline & Number evaluated: 60 \\
\hline \multirow[t]{3}{*}{ Interventions } & Gp A: Twin Block appliance with a passive upper labial bow (CTB-LB) \\
\hline & Gp B: Twin Block appliance was constructed with no labial bow (CTB-NLB) \\
\hline & $\begin{array}{l}\text { Both appliances to be worn full time and only removed for cleaning or during participation of child in } \\
\text { contact sports }\end{array}$ \\
\hline \multirow[t]{2}{*}{ Outcomes } & (i) Overjet \\
\hline & (ii) Skeletal discrepancy \\
\hline \multirow[t]{2}{*}{ Notes } & Duration of intervention: 12 months \\
\hline & $\begin{array}{l}\text { Sample size calculation: "Based on previous research and statistical analysis, a minimum of } 52 \text { subjects } \\
\text { were required ( } 26 \text { in each group) for the study to have a power of } 0.95 \text { to detect a significant difference } \\
\text { of } 5 \text { degrees in upper incisor retroclination at the } 5 \% \text { significance level. To compensate for attrition of } \\
\text { the sample, } 64 \text { subjects were recruited overall. Power calculations were performed on G*Power } 3 \text { (Insti- } \\
\text { tute for Experimental Psychology, Dusseldorf, Germany)." }\end{array}$ \\
\hline
\end{tabular}

\section{Risk of bias}

\section{Bias}

Authors' judgement Support for judgement

Random sequence genera- Low risk tion (selection bias)
"A stratified allocation sequence was generated using an electronic computer program. Patients were stratified according to age and gender. All patients were placed into age- $(62 \mathrm{mo})$ and gender-matched pairs. Pairs of patients were matched according to age and sex, with one patient from each pair randomly selected and allocated to either treatment group (using www.random.org)."

\begin{tabular}{lll}
\hline $\begin{array}{l}\text { Allocation concealment } \\
\text { (selection bias) }\end{array}$ & Low risk & Allocation performed using central website \\
\hline $\begin{array}{l}\text { Blinding of outcome as- } \\
\text { sessment (detection bias) }\end{array}$ & Low risk & "Tracings were carried out in a blind manner by one researcher." \\
$\begin{array}{l}\text { All outcomes } \\
\text { Incomplete outcome data }\end{array}$ & Low risk \\
$\begin{array}{l}\text { (attrition bias) } \\
\text { All outcomes }\end{array}$ & 4 dropouts. 2 in CTB-LB and 2 in CTB-NLB
\end{tabular}

Orthodontic treatment for prominent upper front teeth (Class II malocclusion) in children and adolescents (Review) 
Yaqoob 2012 (Continued)

Reasons for dropouts: failed to attend the follow-up appointment Unlikely to have introduced bias

\begin{tabular}{lll}
\hline $\begin{array}{l}\text { Selective reporting (re- } \\
\text { porting bias) }\end{array}$ & Low risk & All variables reported \\
\hline Other bias & Low risk & No other sources of bias identified \\
\hline
\end{tabular}

$\mathrm{Cl}=$ confidence interval $; \mathrm{Gp}=$ group $\mathrm{mm}=$ millimetre; $\mathrm{RCT}=$ randomised controlled trial; $\mathrm{SD}=$ standard deviation

Characteristics of excluded studies [ordered by study ID]

\begin{tabular}{|c|c|}
\hline Study & Reason for exclusion \\
\hline Aknin 2000 & Comparative study but not randomly allocated to interventions \\
\hline Aksakalli 2016 & $\begin{array}{l}\text { Mean age not less than } 16 \text { years and does not satisfy inclusion criteria for prominent upper } \\
\text { front teeth }\end{array}$ \\
\hline Al-Sibaie 2014 & Inclusion of adults \\
\hline \multirow[t]{2}{*}{ Antonarakis 2015} & Comparative study but not randomly allocated to interventions \\
\hline & Primary outcome was bite force \\
\hline Antunes 2013 & Not RCT \\
\hline Ashmore 2002 & Not RCT \\
\hline Aslan 2014 & Inclusion of Class II division 2 patients \\
\hline Baccetti 2009 & Not RCT \\
\hline Bailleau 2012 & Not RCT \\
\hline Bishara 1995 & Not RCT \\
\hline Booij 2013 & Not RCT \\
\hline Bremen 2015 & Not RCT \\
\hline Burhan 2013 & Inclusion of Class II division 2 patients \\
\hline Chavan 2014 & $\begin{array}{l}\text { Not RCT } \\
\text { Contacted authors. No response received }\end{array}$ \\
\hline Chen 2013 & Inclusion of adults \\
\hline Chen 2015 & $\begin{array}{l}\text { Not RCT } \\
\text { Contacted authors. No response received }\end{array}$ \\
\hline Chintakanon 2000 & Not RCT \\
\hline Chiqueto 2013 & $\begin{array}{l}\text { Not RCT } \\
\text { Contacted authors. No response received }\end{array}$ \\
\hline
\end{tabular}




\begin{tabular}{|c|c|}
\hline Study & Reason for exclusion \\
\hline Collett 2000 & Not RCT \\
\hline Cura 1996 & Not RCT \\
\hline Dahan 1989 & Not RCT \\
\hline Davoody 2011 & $\begin{array}{l}\text { Abstract only. No subsequent publication identified. Insufficient information to include in } \\
\text { review }\end{array}$ \\
\hline De Almeida 2002 & Not RCT \\
\hline DeVincenzo 1989 & Comparative study but not randomly allocated to interventions \\
\hline dos Santos-Pinto 2013 & Not RCT \\
\hline Du 2002 & Comparative study but not randomly allocated to interventions \\
\hline El-Dawlatly 2014 & Not RCT \\
\hline Erbas 2014 & Not RCT \\
\hline Erverdi 1995 & $\begin{array}{l}\text { Not RCT } \\
\text { Contacted authors. No response received }\end{array}$ \\
\hline Falck 1989 & Not RCT \\
\hline Fang 2006 & Not RCT \\
\hline Fernandes 2010 & Not RCT \\
\hline Firouz 1992 & Not RCT \\
\hline Franchi 2013 & Not RCT \\
\hline Franco 2002 & Imaging study of effects of orthodontic treatment on TMJ. Not relevant \\
\hline Freeman 2009 & Not RCT \\
\hline Ghafari 2012 & $\begin{array}{l}\text { Abstract only. No subsequent publication identified. Insufficient information to include in } \\
\text { review }\end{array}$ \\
\hline Ghiglione 2000 & $\begin{array}{l}\text { Abstract only. No subsequent publication identified. Insufficient information to include in } \\
\text { review }\end{array}$ \\
\hline Gianelly 1983 & Not RCT \\
\hline Gong 2014 & Not RCT \\
\hline Gong 2015 & Not RCT \\
\hline Guner 2003 & Not RCT \\
\hline Hagg 2002 & Comparative study but not randomly allocated to interventions \\
\hline Haj-Younis 2016 & Included adults. Average age 22.3 years \\
\hline
\end{tabular}




\begin{tabular}{|c|c|}
\hline Study & Reason for exclusion \\
\hline Harvold 1971 & Not RCT \\
\hline Hemmatpour 2017 & Not an RCT \\
\hline Hiyama 2002 & Not RCT \\
\hline Ingervall 1991 & Comparative study but not randomly allocated to interventions \\
\hline Iscan 1997 & Comparative study but not randomly allocated to interventions \\
\hline Janson 2003 & Not RCT \\
\hline Jarrell 2001 & $\begin{array}{l}\text { Abstract only. No subsequent publication found and insufficient information to include in } \\
\text { review }\end{array}$ \\
\hline Jena 2013 & Not RCT \\
\hline Johansson 2012 & Inclusion of Class II division 2 patients \\
\hline Kalra 1989 & Not RCT \\
\hline Kaya 2013 & Not RCT \\
\hline Keski-Nisula 2003 & Not RCT \\
\hline Kumar 1996 & Not RCT \\
\hline Landazuri 2013 & Not RCT \\
\hline Lange 1995 & Not RCT \\
\hline Lee 2013 & Not RCT \\
\hline Li 2010a & Not RCT \\
\hline Li 2010b & Not RCT \\
\hline Lima 2013 & Not RCT \\
\hline Lombardo 2013 & Not RCT \\
\hline Lund 1998 & Not RCT \\
\hline Mai 2014 & $\begin{array}{l}\text { No information on ANB and overjet } \\
\text { Contacted authors. No response received }\end{array}$ \\
\hline Malmgren 1987 & Not RCT \\
\hline Malta 2010 & Not RCT \\
\hline Mariani 2014 & Not RCT \\
\hline Meral 2004 & Inclusion criteria - not increased overjet \\
\hline
\end{tabular}




\begin{tabular}{|c|c|}
\hline Study & Reason for exclusion \\
\hline Miles 2016 & $\begin{array}{l}\text { No comparison group (no untreated control or another type of orthodontic appliance). } \\
\text { Study not primarily for prominent upper front teeth patients. Outcome of interest not rele- } \\
\text { vant }\end{array}$ \\
\hline Muniandy 2000 & Not Class II \\
\hline Nelson 2000 & Comparative study but not randomly allocated to interventions \\
\hline Neves 2014 & Not RCT \\
\hline Op Heij 1989 & Not RCT \\
\hline Ozturk 1994 & Comparative study but no randomisation \\
\hline Pangrazio 1999 & Retrospective \\
\hline Pangrazio 2003 & Not RCT \\
\hline Parkin 2001 & Not RCT \\
\hline Patel 2013 & Not RCT \\
\hline Phan 2006 & Not RCT \\
\hline Phelan 2012 & Not RCT \\
\hline Pirttiniemi 2005 & Only $20 \%$ of participants had Class II malocclusion \\
\hline Reukers 1998 & Included participants with Class II Division 2 malocclusion \\
\hline Saikoski 2014 & Not RCT \\
\hline Sari 2003 & Comparative study but not randomly allocated to interventions \\
\hline Schaefer 2004 & Not RCT \\
\hline Shannon 2004 & Not RCT \\
\hline Showkatbakhsh 2013 & Not RCT \\
\hline Siara-Olds 2010 & Not RCT \\
\hline Siqueira 2007 & Not RCT \\
\hline Song 2008 & Not RCT \\
\hline Taner 2003 & Comparative retrospective study \\
\hline Thuer 1989 & Comparative study but not randomly allocated to interventions \\
\hline Tumer 1999 & Comparative study but not randomly allocated to interventions \\
\hline Turkkahraman 2016 & Not an RCT \\
\hline Ucem 1998 & Comparison of matched groups \\
\hline
\end{tabular}




\begin{tabular}{|c|c|}
\hline Study & Reason for exclusion \\
\hline Ucuncu 2001 & Comparison of matched groups \\
\hline Uzuner 2014 & Not RCT \\
\hline Wey 2007 & Not RCT \\
\hline Wieslander 1984 & Not RCT \\
\hline Witt 1999 & Comparison of matched groups \\
\hline Yang 2006 & Inclusion of adults \\
\hline You 2006 & Not RCT \\
\hline
\end{tabular}

$\mathrm{RCT}=$ randomised controlled trial; $\mathrm{TMJ}$ = temporomandibular joint

\section{DATA AND ANALYSES}

\section{Comparison 1. Early orthodontic treatment: two-phase versus one-phase treatment}

\begin{tabular}{|c|c|c|c|c|}
\hline Outcome or subgroup title & No. of studies & $\begin{array}{l}\text { No. of partici- } \\
\text { pants }\end{array}$ & Statistical method & Effect size \\
\hline $\begin{array}{l}1 \text { Outcomes at the end of phase I: } \\
\text { functional versus observation }\end{array}$ & 3 & & $\begin{array}{l}\text { Mean Difference (IV, Fixed, } \\
95 \% \mathrm{CI} \text { ) }\end{array}$ & Subtotals only \\
\hline 1.1 Final overjet & 3 & 432 & $\begin{array}{l}\text { Mean Difference (IV, Fixed, } \\
95 \% \mathrm{CI} \text { ) }\end{array}$ & $-4.17[-4.61,-3.73]$ \\
\hline 1.2 Final ANB & 3 & 419 & $\begin{array}{l}\text { Mean Difference (IV, Fixed, } \\
95 \% \mathrm{CI} \text { ) }\end{array}$ & $-0.89[-1.38,-0.40]$ \\
\hline 1.3 PAR score & 2 & 349 & $\begin{array}{l}\text { Mean Difference (IV, Fixed, } \\
95 \% \mathrm{CI} \text { ) }\end{array}$ & $\begin{array}{l}-10.52[-12.32 \\
-8.71]\end{array}$ \\
\hline 1.4 Self concept & 1 & 135 & $\begin{array}{l}\text { Mean Difference (IV, Fixed, } \\
95 \% \mathrm{CI})\end{array}$ & $-3.63[-7.66,0.40]$ \\
\hline $\begin{array}{l}2 \text { Incidence of new incisal trauma } \\
\text { during phase I treatment: functional } \\
\text { versus observation }\end{array}$ & 2 & 281 & $\begin{array}{l}\text { Odds Ratio (M-H, Fixed, 95\% } \\
\mathrm{Cl})\end{array}$ & $0.72[0.35,1.49]$ \\
\hline $\begin{array}{l}3 \text { Outcomes at the end of phase I: } \\
\text { headgear versus observation }\end{array}$ & 2 & & $\begin{array}{l}\text { Mean Difference (IV, Fixed, } \\
95 \% \mathrm{CI})\end{array}$ & Subtotals only \\
\hline 3.1 Final overjet & 2 & 278 & $\begin{array}{l}\text { Mean Difference (IV, Fixed, } \\
95 \% \mathrm{CI} \text { ) }\end{array}$ & $-1.07[-1.63,-0.51]$ \\
\hline 3.2 Final ANB & 2 & 277 & $\begin{array}{l}\text { Mean Difference (IV, Fixed, } \\
95 \% \mathrm{CI} \text { ) }\end{array}$ & $-0.72[-1.18,-0.27]$ \\
\hline
\end{tabular}




\begin{tabular}{|c|c|c|c|c|}
\hline Outcome or subgroup title & No. of studies & $\begin{array}{l}\text { No. of partici- } \\
\text { pants }\end{array}$ & Statistical method & Effect size \\
\hline $\begin{array}{l}4 \text { Incidence of new incisal trauma } \\
\text { during phase I treatment: headgear } \\
\text { versus observation }\end{array}$ & 2 & 285 & $\begin{array}{l}\text { Odds Ratio (M-H, Fixed, 95\% } \\
\mathrm{Cl} \text { ) }\end{array}$ & $0.76[0.37,1.54]$ \\
\hline $\begin{array}{l}5 \text { Outcomes at the end of phase II: } \\
\text { functional ( } 2 \text {-phase) versus adoles- } \\
\text { cent (1-phase) treatment }\end{array}$ & 3 & & $\begin{array}{l}\text { Mean Difference (IV, Fixed, } \\
95 \% \mathrm{Cl} \text { ) }\end{array}$ & Subtotals only \\
\hline 5.1 Final overjet & 3 & 343 & $\begin{array}{l}\text { Mean Difference (IV, Fixed, } \\
95 \% \mathrm{Cl} \text { ) }\end{array}$ & $0.21[-0.10,0.51]$ \\
\hline 5.2 Final ANB & 3 & 347 & $\begin{array}{l}\text { Mean Difference (IV, Fixed, } \\
95 \% \mathrm{Cl} \text { ) }\end{array}$ & $-0.02[-0.47,0.43]$ \\
\hline 5.3 PAR score & 3 & 360 & $\begin{array}{l}\text { Mean Difference (IV, Fixed, } \\
95 \% \mathrm{Cl} \text { ) }\end{array}$ & $0.62[-0.66,1.91]$ \\
\hline 5.4 Self concept & 1 & 132 & $\begin{array}{l}\text { Mean Difference (IV, Fixed, } \\
95 \% \mathrm{Cl} \text { ) }\end{array}$ & $-0.83[-3.97,2.31]$ \\
\hline $\begin{array}{l}6 \text { Incidence of new incisal trauma by } \\
\text { the end of phase II treatment: func- } \\
\text { tional ( } 2 \text {-phase) versus adolescent (1- } \\
\text { phase) treatment }\end{array}$ & 3 & 332 & $\begin{array}{l}\text { Odds Ratio (M-H, Fixed, 95\% } \\
\mathrm{Cl})\end{array}$ & $0.56[0.33,0.95]$ \\
\hline $\begin{array}{l}7 \text { Outcomes at the end of phase II: } \\
\text { headgear ( } 2 \text {-phase) versus adoles- } \\
\text { cent (1-phase) treatment }\end{array}$ & 2 & & $\begin{array}{l}\text { Mean Difference (IV, Fixed, } \\
95 \% \mathrm{Cl} \text { ) }\end{array}$ & Subtotals only \\
\hline 7.1 Final overjet & 2 & 238 & $\begin{array}{l}\text { Mean Difference (IV, Fixed, } \\
95 \% \mathrm{CI} \text { ) }\end{array}$ & $-0.22[-0.56,0.12]$ \\
\hline 7.2 Final ANB & 2 & 231 & $\begin{array}{l}\text { Mean Difference (IV, Fixed, } \\
95 \% \mathrm{CI} \text { ) }\end{array}$ & $-0.27[-0.80,0.26]$ \\
\hline 7.3 PAR score & 2 & 177 & $\begin{array}{l}\text { Mean Difference (IV, Fixed, } \\
95 \% \mathrm{Cl} \text { ) }\end{array}$ & $-1.55[-3.70,0.60]$ \\
\hline $\begin{array}{l}8 \text { Incidence of new incisal trauma by } \\
\text { the end of phase II treatment: head- } \\
\text { gear ( } 2 \text {-phase) versus adolescent (1- } \\
\text { phase) treatment }\end{array}$ & 2 & 237 & $\begin{array}{l}\text { Odds Ratio (M-H, Fixed, 95\% } \\
\mathrm{Cl})\end{array}$ & $0.45[0.25,0.80]$ \\
\hline
\end{tabular}

Analysis 1.1. Comparison 1 Early orthodontic treatment: two-phase versus one-phase treatment, Outcome 1 Outcomes at the end of phase I: functional versus observation.

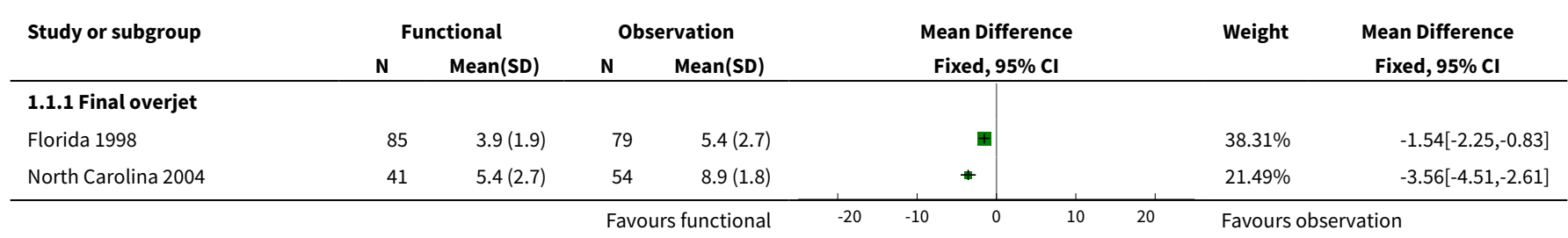




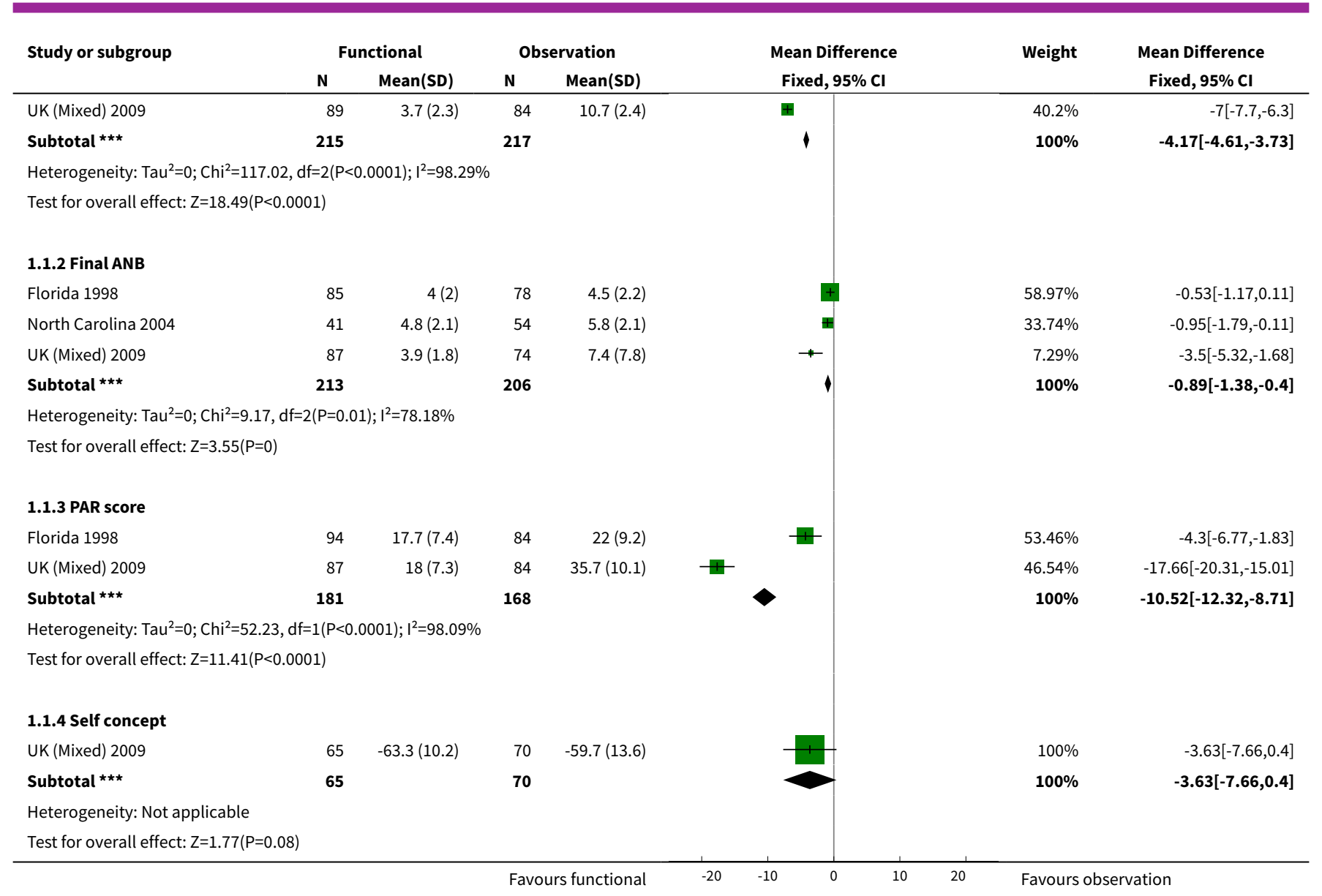

Analysis 1.2. Comparison 1 Early orthodontic treatment: two-phase versus one-phase treatment, Outcome 2 Incidence of new incisal trauma during phase I treatment: functional versus observation.

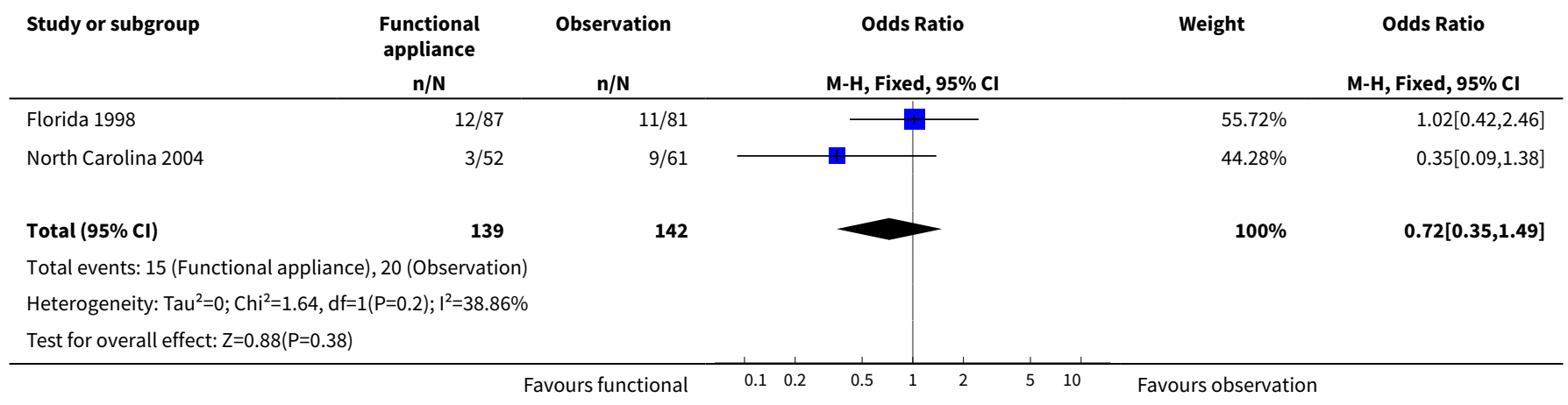


Analysis 1.3. Comparison 1 Early orthodontic treatment: two-phase versus one-phase treatment, Outcome 3 Outcomes at the end of phase l: headgear versus observation.

\begin{tabular}{|c|c|c|c|c|c|c|c|}
\hline \multirow{3}{*}{$\begin{array}{l}\text { Study or subgroup } \\
\text { 1.3.1 Final overjet }\end{array}$} & \multicolumn{2}{|c|}{ Headgear } & \multicolumn{2}{|c|}{ Observation } & \multirow{2}{*}{$\begin{array}{c}\text { Mean Difference } \\
\text { Fixed, } 95 \% \mathrm{Cl}\end{array}$} & \multirow[t]{2}{*}{ Weight } & \multirow{2}{*}{$\begin{array}{c}\text { Mean Difference } \\
\text { Fixed, } 95 \% \mathrm{Cl}\end{array}$} \\
\hline & \multirow[t]{2}{*}{$\mathbf{N}$} & \multirow[t]{2}{*}{ Mean(SD) } & \multirow[t]{2}{*}{$\mathbf{N}$} & \multirow[t]{2}{*}{ Mean(SD) } & & & \\
\hline & & & & & & & \\
\hline Florida 1998 & 95 & $4(2.3)$ & 79 & $5(2.7)$ & & $55.75 \%$ & $-1.01[-1.76,-0.26]$ \\
\hline North Carolina 2004 & 50 & $7.8(2.5)$ & 54 & $8.9(1.8)$ & & $44.25 \%$ & $-1.14[-1.98,-0.3]$ \\
\hline Subtotal $\star \star \star$ & 145 & & 133 & & & $100 \%$ & $-1.07[-1.63,-0.51]$ \\
\hline \multicolumn{8}{|c|}{ Heterogeneity: $\mathrm{Tau}^{2}=0 ; \mathrm{Chi}^{2}=0.05, \mathrm{df}=1(\mathrm{P}=0.82) ; \mathrm{I}^{2}=0 \%$} \\
\hline \multicolumn{8}{|l|}{ 1.3.2 Final ANB } \\
\hline Florida 1998 & 95 & $3.9(1.9)$ & 78 & $4.5(2.2)$ & & $54.98 \%$ & $-0.6[-1.21,0.01]$ \\
\hline North Carolina 2004 & 50 & $4.8(1.5)$ & 54 & $5.7(2)$ & & $45.02 \%$ & $-0.87[-1.55,-0.19]$ \\
\hline Subtotal $\star \star \star$ & 145 & & 132 & & & $100 \%$ & $-0.72[-1.18,-0.27]$ \\
\hline \multicolumn{8}{|c|}{ Heterogeneity: $\operatorname{Tau}^{2}=0 ; \mathrm{Chi}^{2}=0.34, \mathrm{df}=1(\mathrm{P}=0.56) ; \mathrm{I}^{2}=0 \%$} \\
\hline
\end{tabular}

Analysis 1.4. Comparison 1 Early orthodontic treatment: two-phase versus one-phase treatment, Outcome 4 Incidence of new incisal trauma during phase I treatment: headgear versus observation.

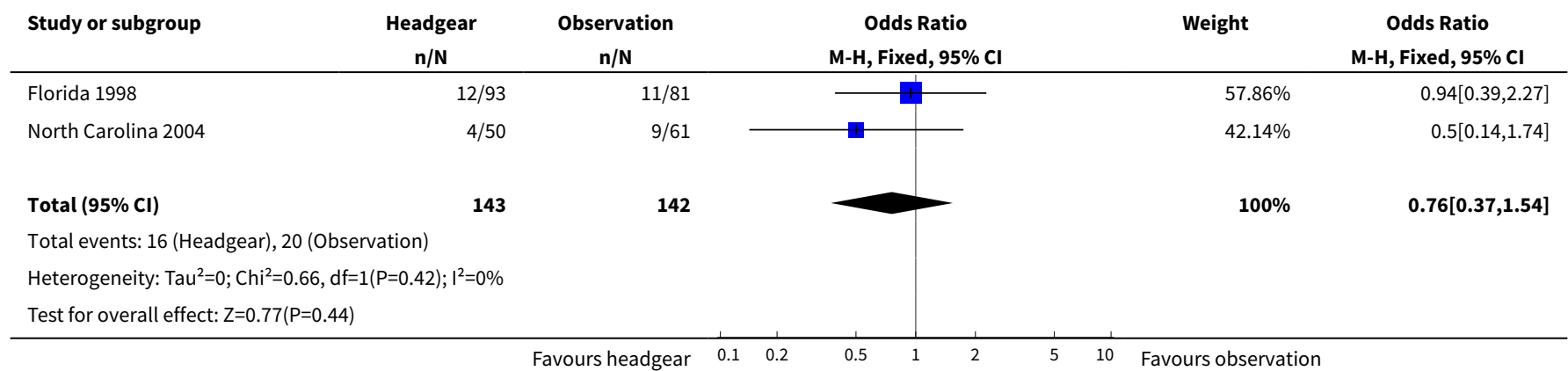

Analysis 1.5. Comparison 1 Early orthodontic treatment: two-phase versus one-phase treatment, Outcome 5 Outcomes at the end of phase II: functional (2-phase) versus adolescent (1-phase) treatment.

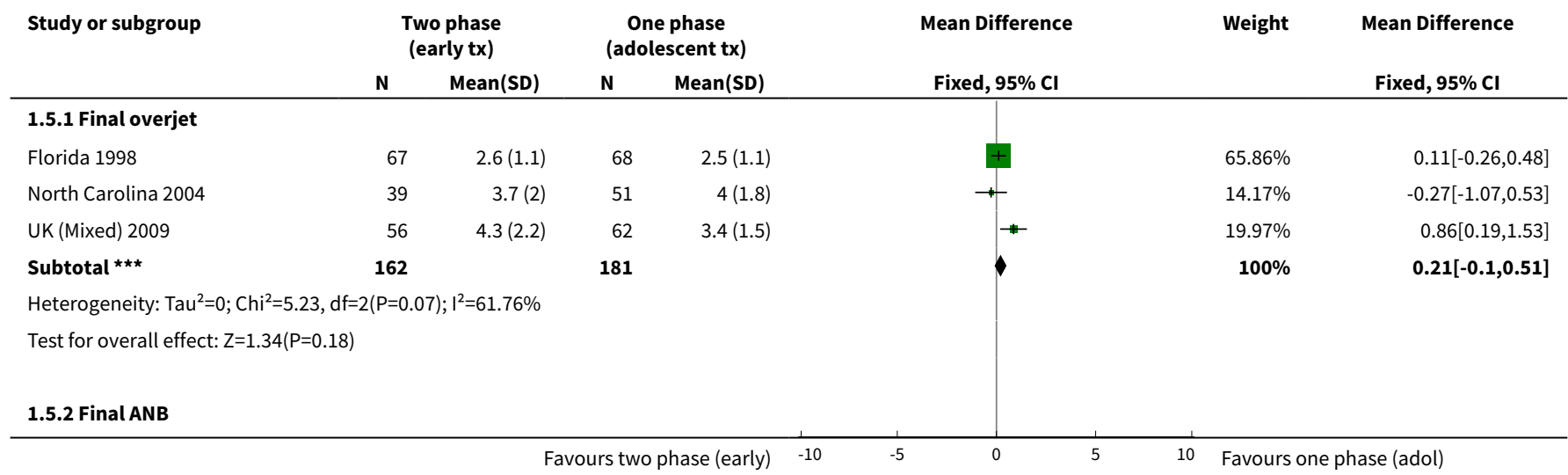




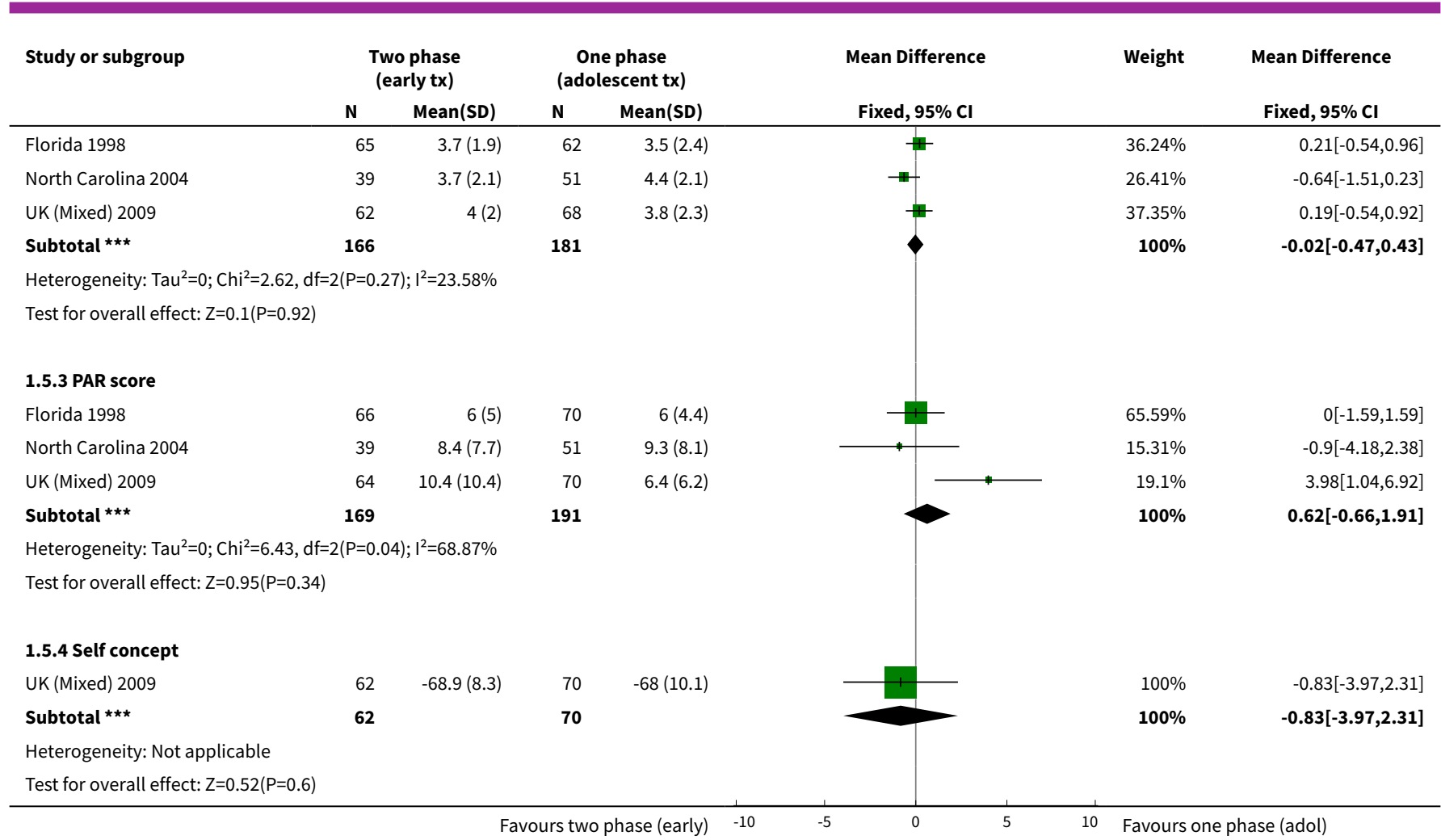

Analysis 1.6. Comparison 1 Early orthodontic treatment: two-phase versus onephase treatment, Outcome 6 Incidence of new incisal trauma by the end of phase II treatment: functional (2-phase) versus adolescent (1-phase) treatment.

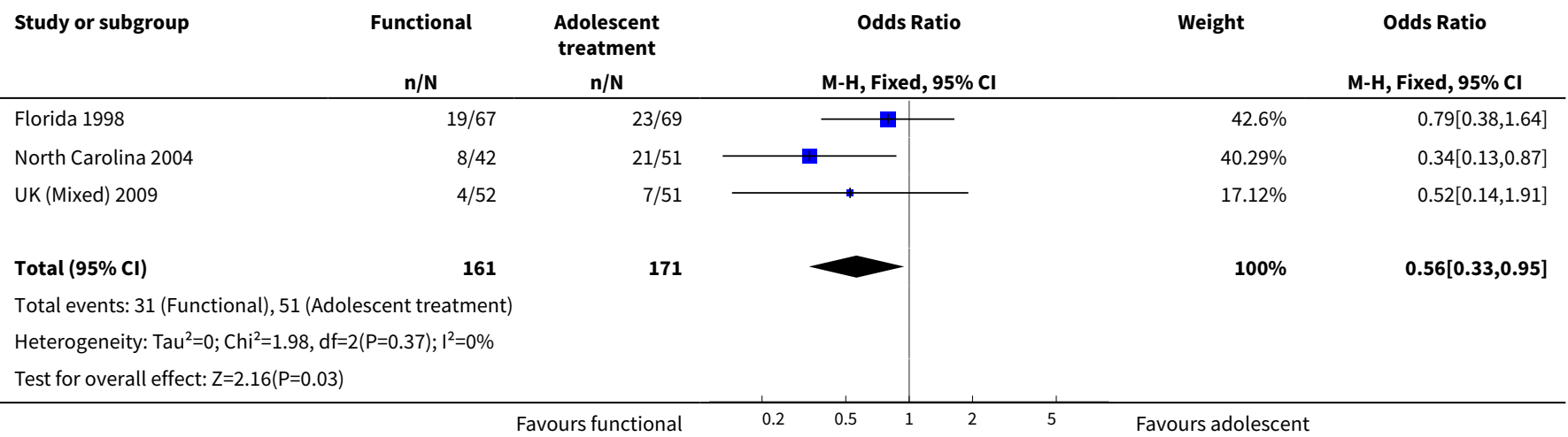

Analysis 1.7. Comparison 1 Early orthodontic treatment: two-phase versus one-phase treatment, Outcome 7 Outcomes at the end of phase II: headgear (2-phase) versus adolescent (1-phase) treatment.

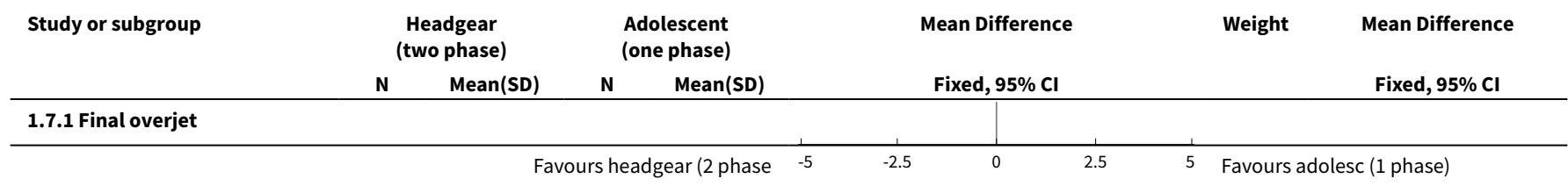




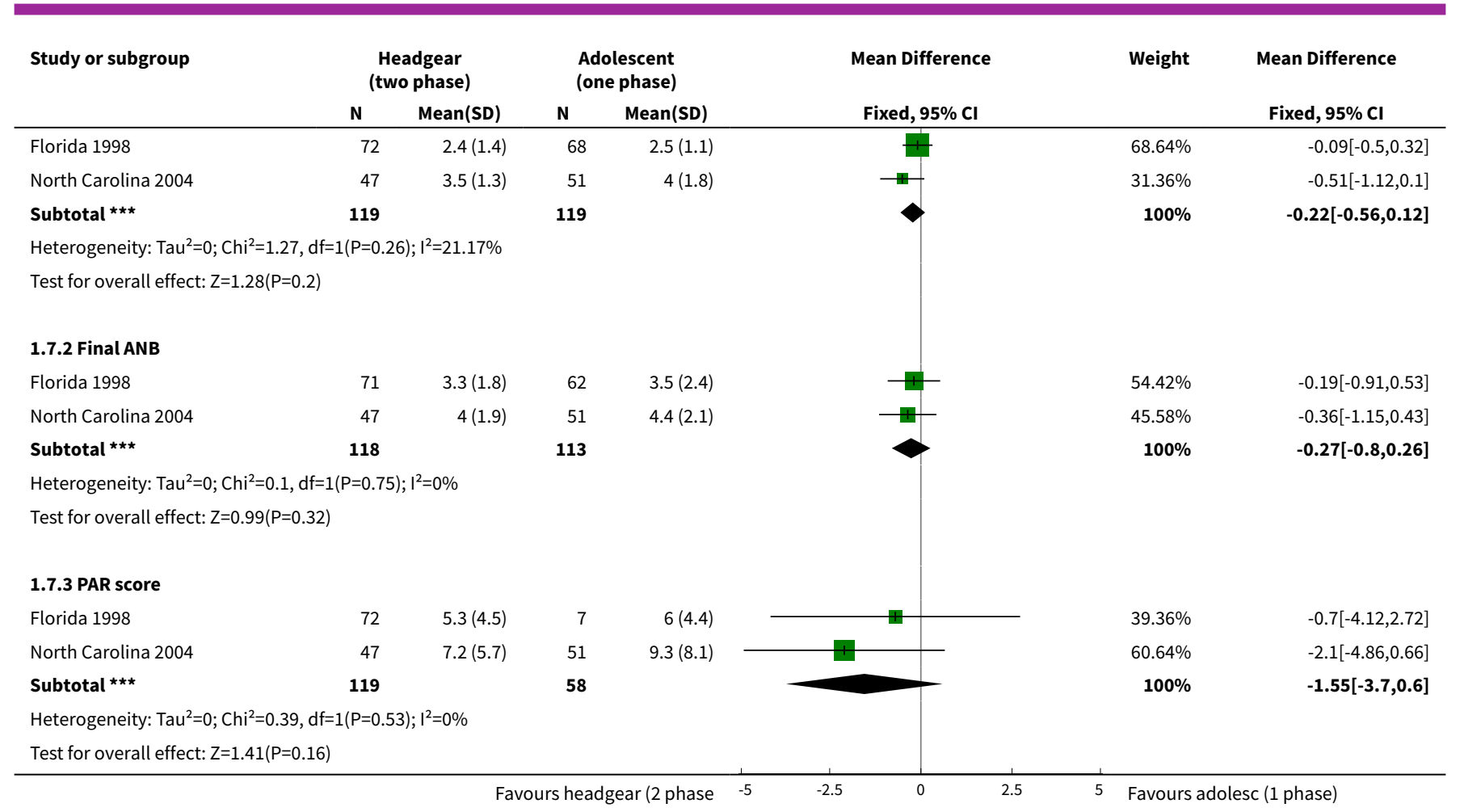

Analysis 1.8. Comparison 1 Early orthodontic treatment: two-phase versus onephase treatment, Outcome 8 Incidence of new incisal trauma by the end of phase II treatment: headgear (2-phase) versus adolescent (1-phase) treatment.

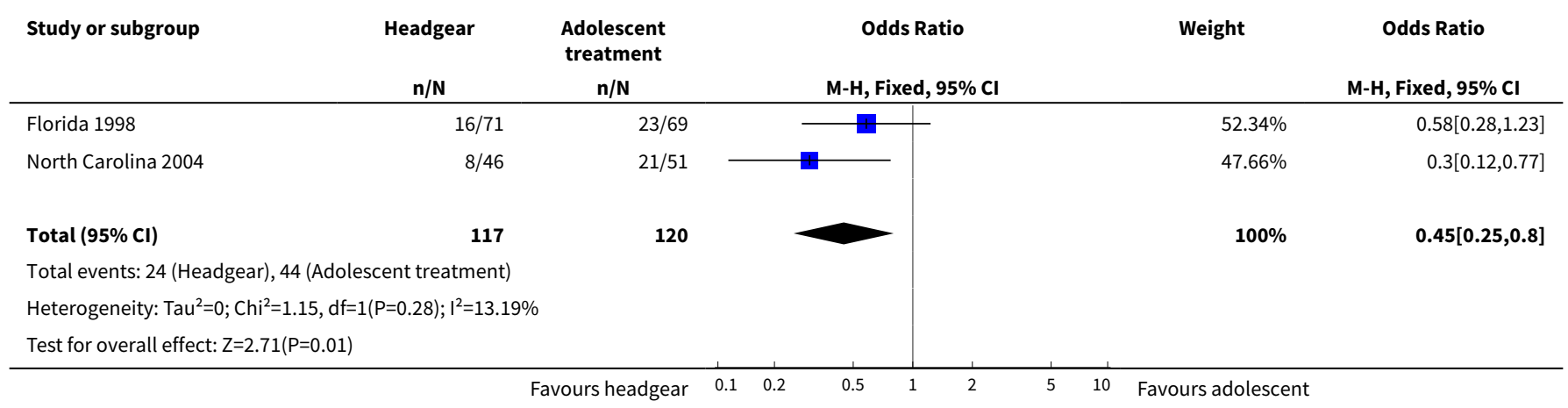

\section{Comparison 2. Early orthodontic treatment: two-phase appliance 1 (headgear) versus appliance 2 (functional)}

\begin{tabular}{|c|c|c|c|c|}
\hline Outcome or subgroup title & No. of studies & $\begin{array}{l}\text { No. of partici- } \\
\text { pants }\end{array}$ & Statistical method & Effect size \\
\hline $\begin{array}{l}1 \text { Outcomes at the end of phase I: } \\
\text { headgear versus functional }\end{array}$ & 2 & & $\begin{array}{l}\text { Mean Difference (IV, Fixed, } \\
95 \% \mathrm{Cl} \text { ) }\end{array}$ & Subtotals only \\
\hline 1.1 Final overjet & 2 & 271 & $\begin{array}{l}\text { Mean Difference (IV, Fixed, } \\
95 \% \mathrm{CI} \text { ) }\end{array}$ & $0.75[0.21,1.29]$ \\
\hline
\end{tabular}




\begin{tabular}{|c|c|c|c|c|}
\hline Outcome or subgroup title & No. of studies & $\begin{array}{l}\text { No. of partici- } \\
\text { pants }\end{array}$ & Statistical method & Effect size \\
\hline 1.2 Final ANB & 2 & 271 & $\begin{array}{l}\text { Mean Difference (IV, Fixed, } \\
95 \% \mathrm{CI})\end{array}$ & $-0.04[-0.49,0.41]$ \\
\hline $\begin{array}{l}2 \text { Incidence of new incisal trauma } \\
\text { during phase I treatment: headgear } \\
\text { versus functional }\end{array}$ & 2 & 282 & $\begin{array}{l}\text { Odds Ratio (M-H, Fixed, 95\% } \\
\mathrm{Cl} \text { ) }\end{array}$ & $1.02[0.48,2.17]$ \\
\hline $\begin{array}{l}3 \text { Outcomes at the end of phase II: } \\
\text { headgear versus functional }\end{array}$ & 2 & & $\begin{array}{l}\text { Mean Difference (IV, Fixed, } \\
95 \% \mathrm{CI})\end{array}$ & Subtotals only \\
\hline 3.1 Final overjet & 2 & 225 & $\begin{array}{l}\text { Mean Difference (IV, Fixed, } \\
95 \% \mathrm{CI})\end{array}$ & $-0.21[-0.57,0.15]$ \\
\hline 3.2 Final ANB & 2 & 222 & $\begin{array}{l}\text { Mean Difference (IV, Fixed, } \\
95 \% \mathrm{CI})\end{array}$ & $-0.17[-0.67,0.34]$ \\
\hline 3.3 PAR score & 2 & 224 & $\begin{array}{l}\text { Mean Difference (IV, Fixed, } \\
95 \% \mathrm{CI})\end{array}$ & $-0.81[-2.21,0.58]$ \\
\hline $\begin{array}{l}4 \text { Incidence of new incisal trauma by } \\
\text { the end of phase II treatment: head- } \\
\text { gear versus functional appliance }\end{array}$ & 2 & 226 & $\begin{array}{l}\text { Odds Ratio (M-H, Fixed, 95\% } \\
\text { Cl) }\end{array}$ & $0.78[0.42,1.47]$ \\
\hline
\end{tabular}

\section{Analysis 2.1. Comparison 2 Early orthodontic treatment: two-phase appliance 1 (headgear) versus appliance 2 (functional), Outcome 1 Outcomes at the end of phase I: headgear versus functional.}

\begin{tabular}{|c|c|c|c|c|c|c|c|}
\hline \multirow[t]{2}{*}{ Study or subgroup } & \multicolumn{2}{|c|}{ Headgear } & \multicolumn{2}{|c|}{ Functional } & \multirow{2}{*}{$\begin{array}{c}\text { Mean Difference } \\
\text { Fixed, } 95 \% \mathrm{Cl}\end{array}$} & \multirow[t]{2}{*}{ Weight } & \multirow{2}{*}{$\begin{array}{c}\text { Mean Difference } \\
\text { Fixed, } 95 \% \mathrm{Cl}\end{array}$} \\
\hline & $\mathbf{N}$ & $\operatorname{Mean}(S D)$ & $\mathbf{N}$ & $\operatorname{Mean}(\mathrm{SD})$ & & & \\
\hline \multicolumn{8}{|l|}{ 2.1.1 Final overjet } \\
\hline Florida 1998 & 95 & $4(2.3)$ & 85 & $3.8(1.9)$ & & $74.88 \%$ & $0.19[-0.43,0.81]$ \\
\hline North Carolina 2004 & 50 & $7.8(2.5)$ & 41 & $5.4(2.7)$ & —- & $25.12 \%$ & $2.42[1.35,3.49]$ \\
\hline Subtotal $\star \star \star$ & 145 & & 126 & & & $100 \%$ & $0.75[0.21,1.29]$ \\
\hline \multicolumn{8}{|c|}{ Heterogeneity: Tau $^{2}=0 ; \mathrm{Chi}^{2}=12.54, \mathrm{df}=1(\mathrm{P}=0) ; \mathrm{I}^{2}=92.03 \%$} \\
\hline \multicolumn{8}{|c|}{ Test for overall effect: $Z=2.75(P=0.01)$} \\
\hline \multicolumn{8}{|l|}{ 2.1.2 Final ANB } \\
\hline Florida 1998 & 95 & $3.9(1.9)$ & 85 & $4(2)$ & & $65.08 \%$ & $-0.07[-0.63,0.49]$ \\
\hline North Carolina 2004 & 50 & $4.8(1.5)$ & 41 & $4.8(2.1)$ & & $34.92 \%$ & $0.01[-0.75,0.77]$ \\
\hline 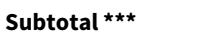 & 145 & & 126 & & & $100 \%$ & $-0.04[-0.49,0.41]$ \\
\hline \multicolumn{8}{|c|}{ Heterogeneity: $\mathrm{Tau}^{2}=0 ; \mathrm{Chi}^{2}=0.03, \mathrm{df}=1(\mathrm{P}=0.87) ; \mathrm{I}^{2}=0 \%$} \\
\hline
\end{tabular}


Analysis 2.2. Comparison 2 Early orthodontic treatment: two-phase appliance 1 (headgear) versus appliance 2 (functional), Outcome $\mathbf{2}$ Incidence of new incisal trauma during phase I treatment: headgear versus functional.

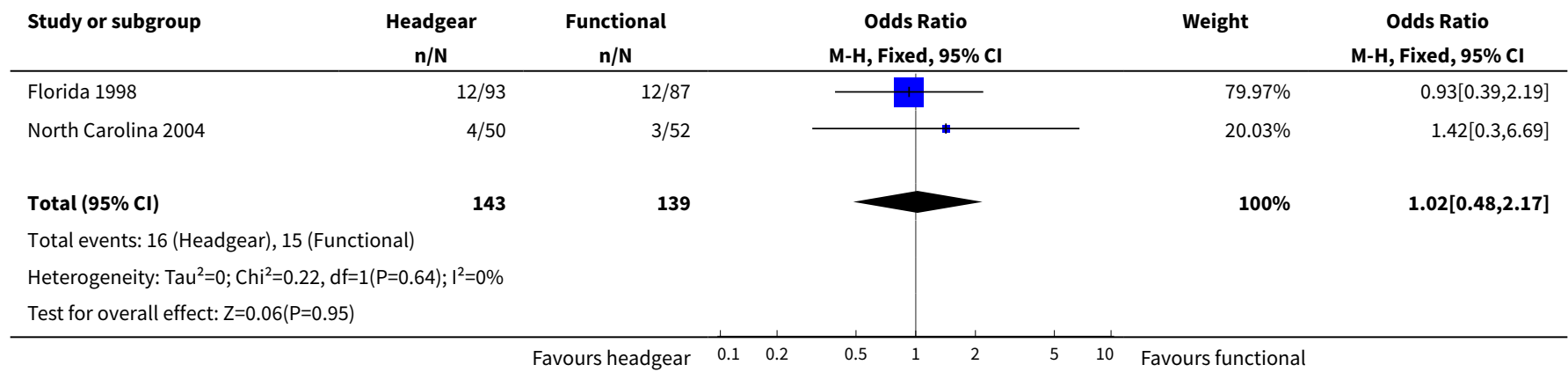

Analysis 2.3. Comparison 2 Early orthodontic treatment: two-phase appliance 1 (headgear) versus appliance 2 (functional), Outcome 3 Outcomes at the end of phase II: headgear versus functional.

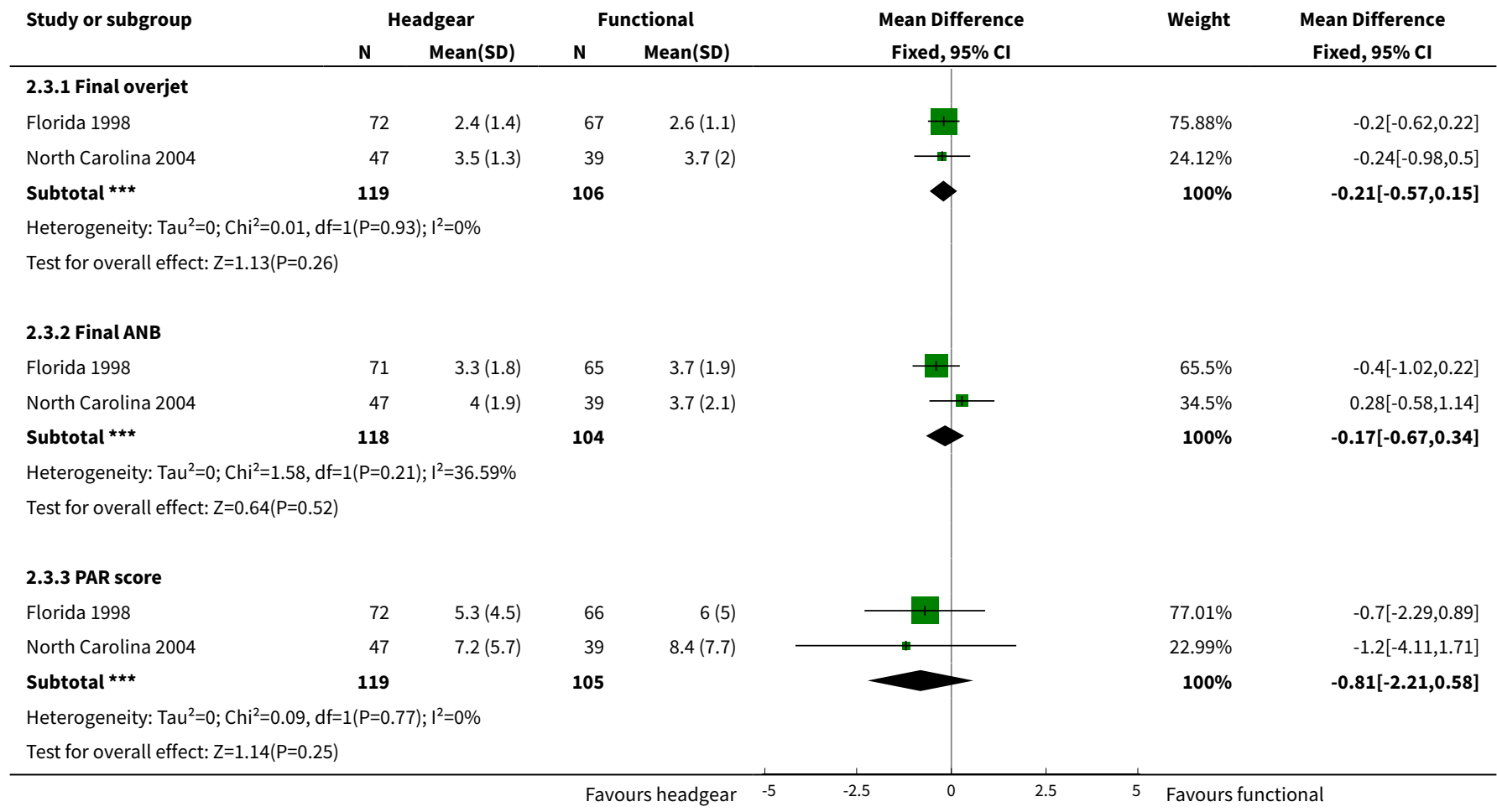

Analysis 2.4. Comparison 2 Early orthodontic treatment: two-phase appliance 1 (headgear) versus appliance 2 (functional), Outcome 4 Incidence of new incisal trauma by the end of phase II treatment: headgear versus functional appliance.

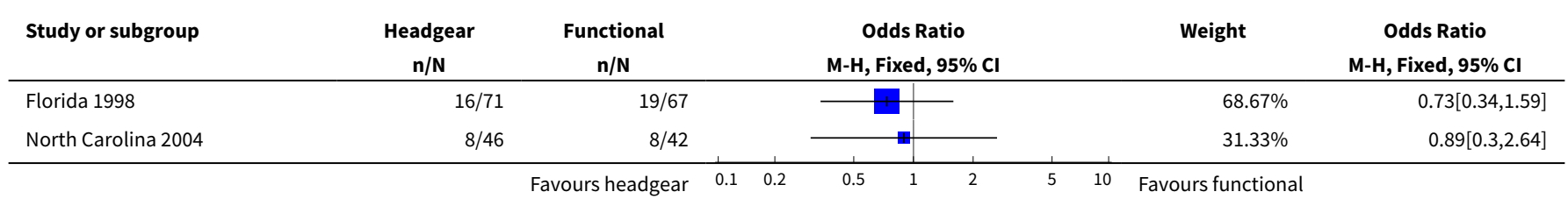




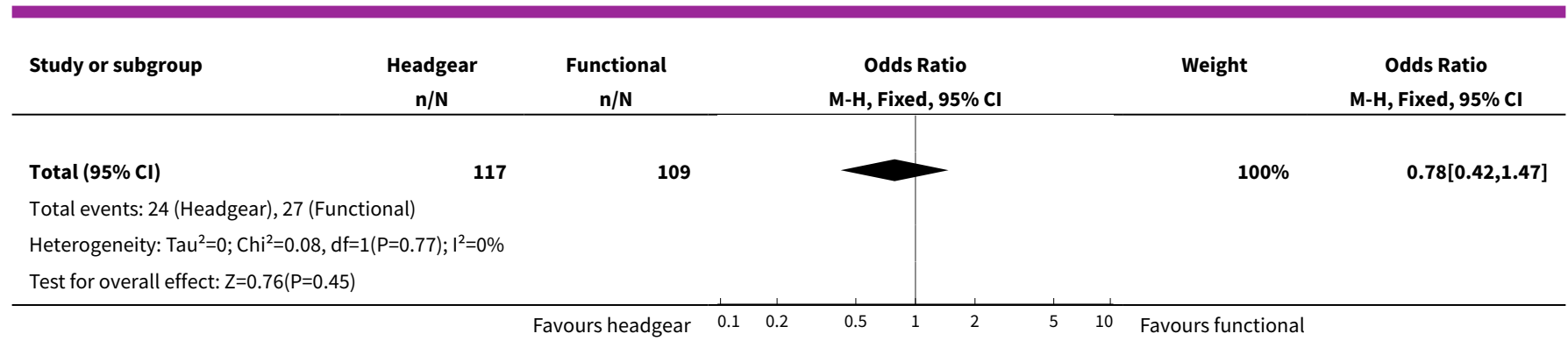

\section{Comparison 3. Late orthodontic treatment: functional versus no treatment}

\begin{tabular}{lllll}
\hline $\begin{array}{l}\text { Outcome or subgroup } \\
\text { title }\end{array}$ & No. of studies & $\begin{array}{l}\text { No. of partici- } \\
\text { pants }\end{array}$ & Statistical method & Effect size \\
\hline 1 Final overjet & 5 & & Mean Difference (IV, Fixed, 95\% CI) & Subtotals only \\
\hline $\begin{array}{l}1.1 \text { Fixed functional } \\
\text { 1.2 Removable func- } \\
\text { tional }\end{array}$ & 2 & 61 & Mean Difference (IV, Fixed, 95\% CI) & $-5.46[-6.63,-4.28]$ \\
\hline $\begin{array}{l}2 \text { Final ANB } \\
\text { 2.1 Fixed functional }\end{array}$ & 5 & 122 & Mean Difference (IV, Fixed, 95\% CI) & $-4.62[-5.33,-3.92]$ \\
\hline $\begin{array}{l}2.2 \text { Removable func- } \\
\text { tional }\end{array}$ & 2 & 89 & Mean Difference (IV, Fixed, 95\% CI) & Subtotals only \\
\hline
\end{tabular}

\section{Analysis 3.1. Comparison 3 Late orthodontic treatment: functional versus no treatment, Outcome 1 Final overjet.}

\begin{tabular}{|c|c|c|c|c|c|c|c|}
\hline \multirow{3}{*}{$\begin{array}{l}\text { Study or subgroup } \\
\text { 3.1.1 Fixed functiona }\end{array}$} & \multicolumn{2}{|c|}{ Favours functional } & \multicolumn{2}{|c|}{ No treatment } & \multirow{2}{*}{$\begin{array}{c}\text { Mean Difference } \\
\text { Fixed, } 95 \% \mathrm{Cl}\end{array}$} & \multirow[t]{2}{*}{ Weight } & \multirow{2}{*}{$\begin{array}{c}\text { Mean Difference } \\
\text { Fixed, } 95 \% \mathrm{Cl}\end{array}$} \\
\hline & \multirow[t]{2}{*}{$\mathbf{N}$} & \multirow[t]{2}{*}{ Mean(SD) } & \multirow[t]{2}{*}{$\mathbf{N}$} & \multirow[t]{2}{*}{$\operatorname{Mean}(S D)$} & & & \\
\hline & & & & & & & \\
\hline Alali 2014 & 21 & $4.4(1.5)$ & 17 & $7.5(3)$ & + & $55.86 \%$ & $-3.05[-4.62,-1.48]$ \\
\hline Eissa 2017 & 14 & $2.1(1.2)$ & 9 & $10.6(2.5)$ & 廿 & $44.14 \%$ & $-8.5[-10.27,-6.73]$ \\
\hline 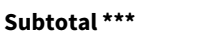 & 35 & & 26 & & 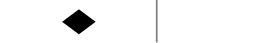 & $100 \%$ & $-5.46[-6.63,-4.28]$ \\
\hline \multicolumn{8}{|c|}{ Heterogeneity: Tau $^{2}=0 ; \mathrm{Chi}^{2}=20.37, \mathrm{df}=1(P<0.0001) ;\left.\right|^{2}=95.09 \%$} \\
\hline \multicolumn{8}{|c|}{ 3.1.2 Removable functional } \\
\hline Cura 1997 & 27 & $4.7(1.8)$ & 20 & $9.9(2.5)$ & $\rightarrow$ & $29.7 \%$ & $-5.22[-6.51,-3.93]$ \\
\hline Martina 2013 & 23 & $3.6(1.3)$ & 23 & $7.8(1.8)$ & + & $60.06 \%$ & $-4.2[-5.11,-3.29]$ \\
\hline New Zealand 2000 & 12 & $-5.2(3.8)$ & 17 & $0.2(1.2)$ & 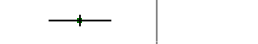 & $10.23 \%$ & $-5.38[-7.58,-3.18]$ \\
\hline Subtotal $* \star \star$ & 62 & & 60 & & $\diamond$ & $100 \%$ & $-4.62[-5.33,-3.92]$ \\
\hline \multicolumn{8}{|c|}{ Test for overall effect: $Z=12.89(P<0.0001)$} \\
\hline & & & Fave & functional & -10 & Favours & tment \\
\hline
\end{tabular}


Analysis 3.2. Comparison 3 Late orthodontic treatment: functional versus no treatment, Outcome 2 Final ANB.

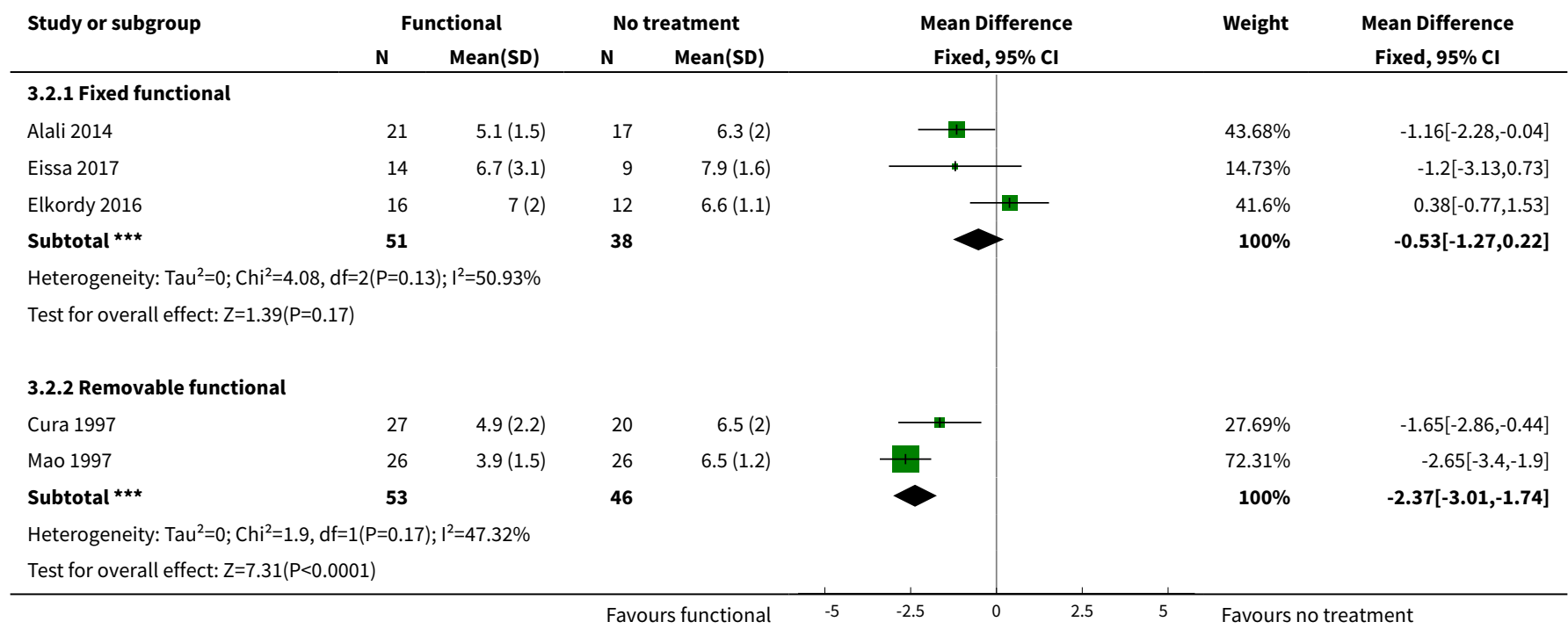

\section{Comparison 4. Late orthodontic treatment: different types of appliances used for late treatment}

\begin{tabular}{|c|c|c|c|c|}
\hline Outcome or subgroup title & No. of studies & $\begin{array}{l}\text { No. of partici- } \\
\text { pants }\end{array}$ & Statistical method & Effect size \\
\hline $\begin{array}{l}1 \text { Twin Block versus other func- } \\
\text { tional appliances (R-appliance, } \\
\text { Bionator, Bite-Jumping appli- } \\
\text { ance, Dynamax and Herbst) }\end{array}$ & 6 & & $\begin{array}{l}\text { Mean Difference (IV, Random, } \\
95 \% \mathrm{CI})\end{array}$ & Subtotals only \\
\hline 1.1 Final overjet & 4 & 259 & $\begin{array}{l}\text { Mean Difference (IV, Random, } \\
95 \% \mathrm{CI})\end{array}$ & $0.08[-0.60,0.76]$ \\
\hline 1.2 Final ANB & 6 & 320 & $\begin{array}{l}\text { Mean Difference (IV, Random, } \\
95 \% \mathrm{CI} \text { ) }\end{array}$ & $-0.56[-0.96,-0.16]$ \\
\hline $\begin{array}{l}2 \text { Twin Block conventional versus } \\
\text { other Twin Block modifications }\end{array}$ & 2 & & $\begin{array}{l}\text { Mean Difference (IV, Fixed, 95\% } \\
\mathrm{CI})\end{array}$ & Subtotals only \\
\hline 2.1 Final overjet & 2 & 196 & $\begin{array}{l}\text { Mean Difference (IV, Fixed, 95\% } \\
\text { CI) }\end{array}$ & $-0.23[-0.67,0.22]$ \\
\hline $\begin{array}{l}3 \text { Functional (Activator) versus } \\
\text { prefabricated functional my- } \\
\text { obrace appliance (PFA) }\end{array}$ & 1 & & $\begin{array}{l}\text { Mean Difference (IV, Fixed, 95\% } \\
\mathrm{CI} \text { ) }\end{array}$ & Subtotals only \\
\hline 3.1 Final overjet & 1 & 97 & $\begin{array}{l}\text { Mean Difference (IV, Fixed, 95\% } \\
\mathrm{CI} \text { ) }\end{array}$ & $-0.60[-1.63,0.43]$ \\
\hline $\begin{array}{l}4 \text { Functional (Activator) versus } \\
\text { fixed functional (FORSUS FRD EZ) }\end{array}$ & 1 & & $\begin{array}{l}\text { Mean Difference (IV, Fixed, 95\% } \\
\text { Cl) }\end{array}$ & Subtotals only \\
\hline 4.1 Final overjet & 1 & 24 & $\begin{array}{l}\text { Mean Difference (IV, Fixed, 95\% } \\
\text { CI) }\end{array}$ & $2.19[0.58,3.80]$ \\
\hline
\end{tabular}




\begin{tabular}{|c|c|c|c|c|}
\hline Outcome or subgroup title & No. of studies & $\begin{array}{l}\text { No. of partici- } \\
\text { pants }\end{array}$ & Statistical method & Effect size \\
\hline 4.2 Final ANB & 1 & 24 & $\begin{array}{l}\text { Mean Difference (IV, Fixed, 95\% } \\
\mathrm{CI} \text { ) }\end{array}$ & $-1.74[-3.28,-0.20]$ \\
\hline $\begin{array}{l}5 \text { Fixed functional (FORSUS FRD) } \\
\text { versus fixed functional with mi- } \\
\text { ni-implants (FMI) }\end{array}$ & 2 & & $\begin{array}{l}\text { Mean Difference (IV, Fixed, 95\% } \\
\mathrm{CI} \text { ) }\end{array}$ & Subtotals only \\
\hline 5.1 Final overjet & 1 & 29 & $\begin{array}{l}\text { Mean Difference (IV, Fixed, 95\% } \\
\mathrm{Cl} \text { ) }\end{array}$ & $-0.36[-1.07,0.35]$ \\
\hline 5.2 Final ANB & 2 & 60 & $\begin{array}{l}\text { Mean Difference (IV, Fixed, 95\% } \\
\mathrm{CI} \text { ) }\end{array}$ & $0.22[-0.86,1.30]$ \\
\hline $\begin{array}{l}6 \text { Fixed functional (FORSUS FRD) } \\
\text { versus fixed functional with mi- } \\
\text { ni-implants (FMI) - patient satis- } \\
\text { faction with results }\end{array}$ & 1 & 32 & Odds Ratio (M-H, Fixed, 95\% Cl) & $0.18[0.01,3.97]$ \\
\hline 7 R-appliance versus AIBP & 1 & & $\begin{array}{l}\text { Mean Difference (IV, Fixed, 95\% } \\
\mathrm{Cl} \text { ) }\end{array}$ & Subtotals only \\
\hline 7.1 Final ANB & 1 & 50 & $\begin{array}{l}\text { Mean Difference (IV, Fixed, 95\% } \\
\mathrm{CI} \text { ) }\end{array}$ & $-0.30[-0.99,0.39]$ \\
\hline $\begin{array}{l}8 \text { Removable functional appli- } \\
\text { ance versus fixed functional ap- } \\
\text { pliance }\end{array}$ & 3 & & $\begin{array}{l}\text { Mean Difference (IV, Fixed, 95\% } \\
\mathrm{CI} \text { ) }\end{array}$ & Subtotals only \\
\hline 8.1 Final overjet & 2 & 154 & $\begin{array}{l}\text { Mean Difference (IV, Fixed, 95\% } \\
\mathrm{CI} \text { ) }\end{array}$ & $0.74[0.15,1.33]$ \\
\hline 8.2 Final ANB & 3 & 185 & $\begin{array}{l}\text { Mean Difference (IV, Fixed, 95\% } \\
\mathrm{CI} \text { ) }\end{array}$ & $-1.04[-1.60,-0.49]$ \\
\hline $\begin{array}{l}9 \text { FORSUS versus intermaxillary } \\
\text { elastics }\end{array}$ & 1 & & $\begin{array}{l}\text { Mean Difference (IV, Fixed, 95\% } \\
\mathrm{CI} \text { ) }\end{array}$ & Subtotals only \\
\hline 9.1 Final overjet & 1 & 28 & $\begin{array}{l}\text { Mean Difference (IV, Fixed, 95\% } \\
\mathrm{CI} \text { ) }\end{array}$ & $0.28[-0.35,0.91]$ \\
\hline 9.2 Final ANB & 1 & 28 & $\begin{array}{l}\text { Mean Difference (IV, Fixed, 95\% } \\
\mathrm{Cl} \text { ) }\end{array}$ & $-0.90[-1.96,0.16]$ \\
\hline $\begin{array}{l}10 \text { FMA stepwise (SWG) versus } \\
\text { FMA single step (SSG) }\end{array}$ & 1 & & $\begin{array}{l}\text { Mean Difference (IV, Fixed, 95\% } \\
\mathrm{Cl} \text { ) }\end{array}$ & Subtotals only \\
\hline 10.1 Final overjet & 1 & 34 & $\begin{array}{l}\text { Mean Difference (IV, Fixed, 95\% } \\
\mathrm{CI} \text { ) }\end{array}$ & $0.23[-0.26,0.72]$ \\
\hline 10.2 Final ANB & 1 & 34 & $\begin{array}{l}\text { Mean Difference (IV, Fixed, 95\% } \\
\mathrm{CI} \text { ) }\end{array}$ & $-0.69[-1.19,-0.19]$ \\
\hline $\begin{array}{l}11 \text { Harvold Activator versus } \\
\text { Frankel function regulator }\end{array}$ & 1 & 25 & $\begin{array}{l}\text { Mean Difference (IV, Fixed, 95\% } \\
\mathrm{CI} \text { ) }\end{array}$ & $-2.93[-5.37,-0.49]$ \\
\hline
\end{tabular}




\begin{tabular}{lllll}
\hline Outcome or subgroup title & No. of studies & $\begin{array}{l}\text { No. of partici- } \\
\text { pants }\end{array}$ & Statistical method & Effect size \\
\hline 11.1 Overjet change & 1 & 25 & $\begin{array}{l}\text { Mean Difference (IV, Fixed, 95\% } \\
\text { CI) }\end{array}$ & $-2.93[-5.37,-0.49]$ \\
\hline
\end{tabular}

Analysis 4.1. Comparison 4 Late orthodontic treatment: different types of appliances used for late treatment, Outcome 1 Twin Block versus other functional appliances (R-appliance, Bionator, Bite-Jumping appliance, Dynamax and Herbst).

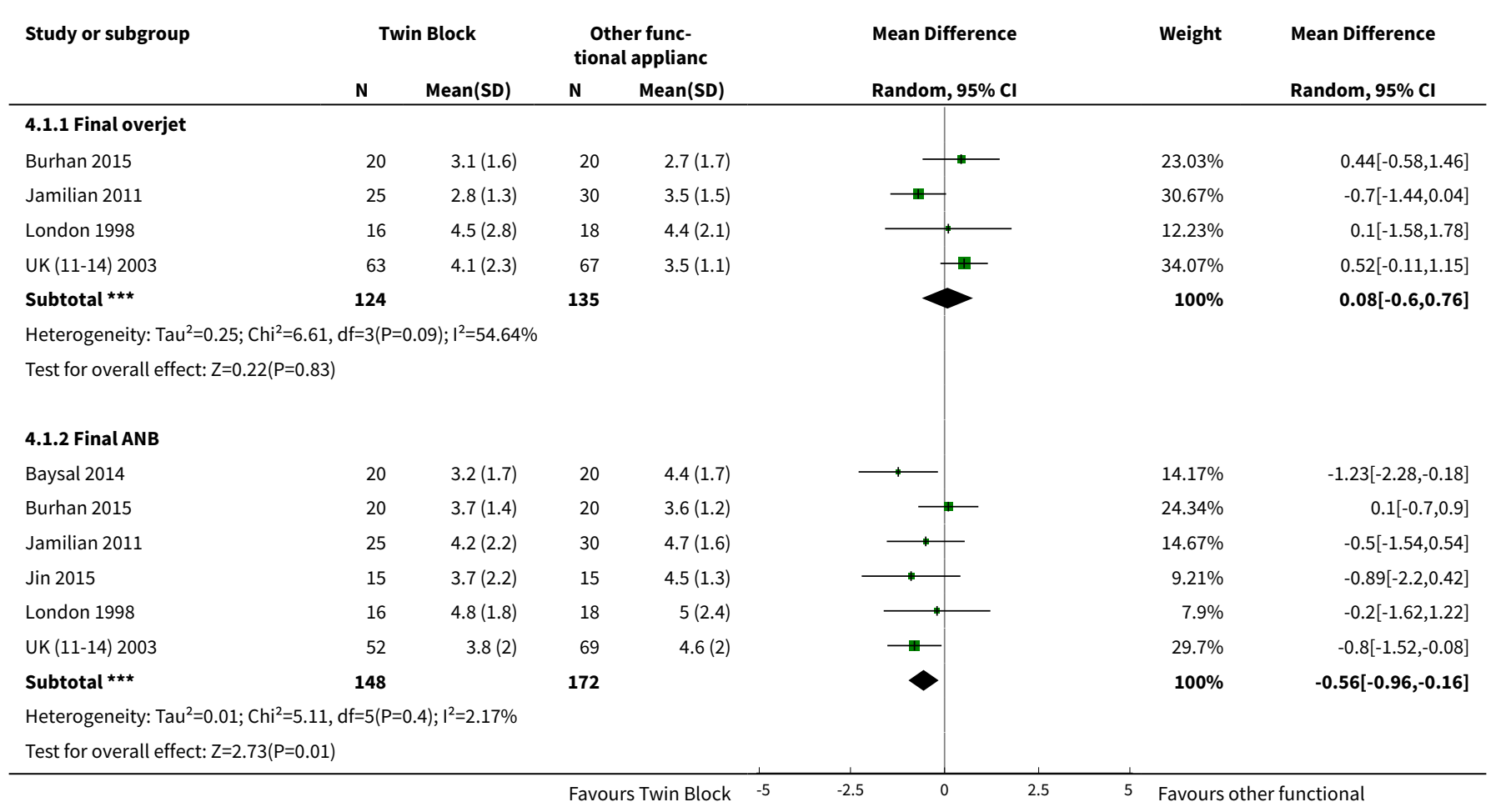

Analysis 4.2. Comparison 4 Late orthodontic treatment: different types of appliances used for late treatment, Outcome $\mathbf{2}$ Twin Block conventional versus other Twin Block modifications.

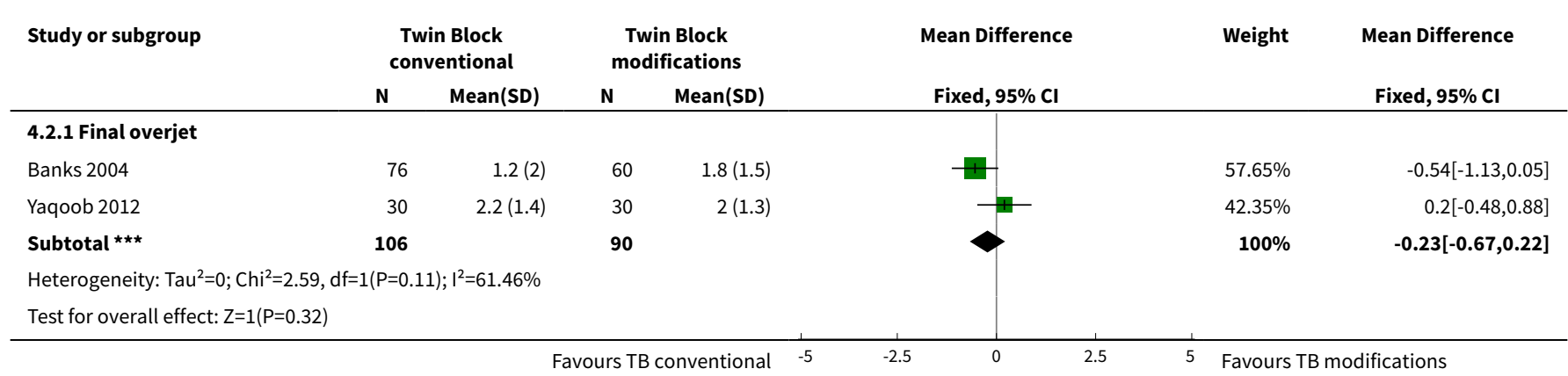


Analysis 4.3. Comparison 4 Late orthodontic treatment: different types of appliances used for late treatment, Outcome 3 Functional (Activator) versus prefabricated functional myobrace appliance (PFA).

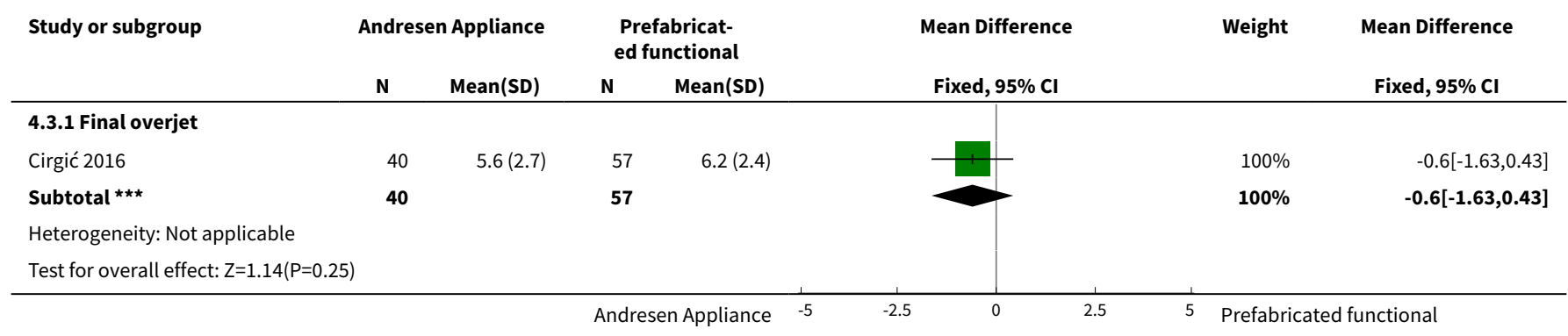

Analysis 4.4. Comparison 4 Late orthodontic treatment: different types of appliances used for late treatment, Outcome 4 Functional (Activator) versus fixed functional (FORSUS FRD EZ).

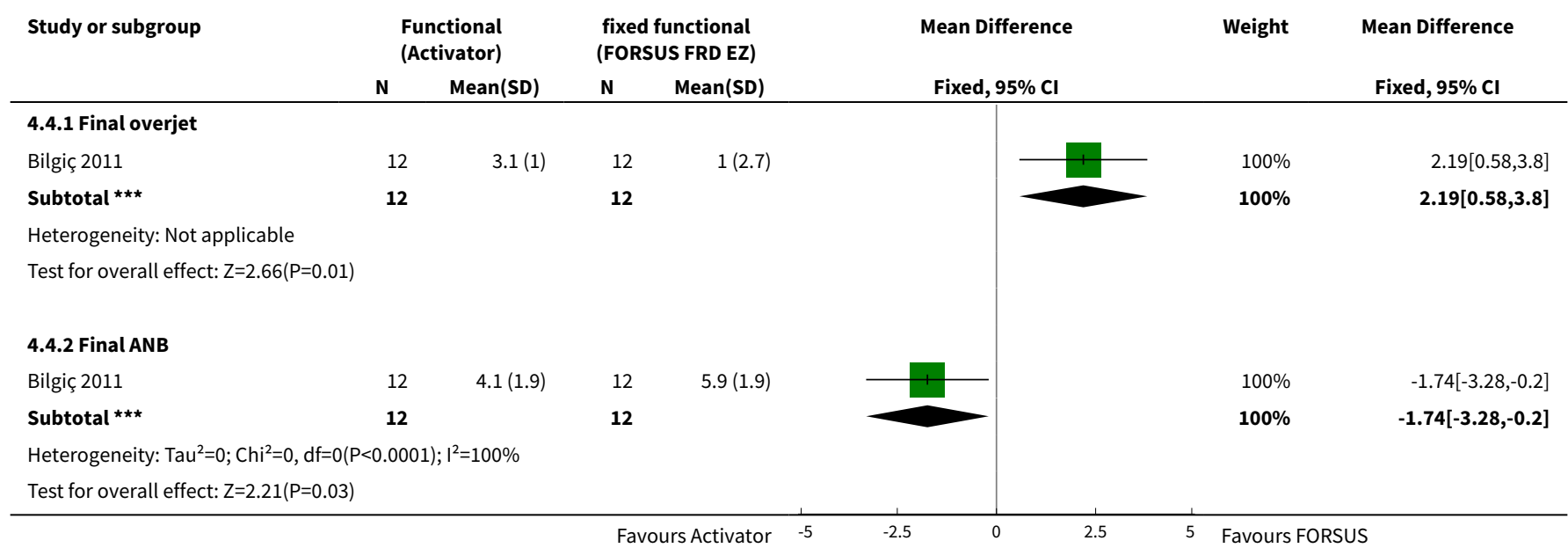

Analysis 4.5. Comparison 4 Late orthodontic treatment: different types of appliances used for late treatment, Outcome 5 Fixed functional (FORSUS FRD) versus fixed functional with mini-implants (FMI).

\begin{tabular}{|c|c|c|c|c|c|c|c|}
\hline \multirow[t]{2}{*}{ Study or subgroup } & \multicolumn{2}{|c|}{ FFRD } & \multicolumn{2}{|c|}{ FMI } & \multirow{2}{*}{$\begin{array}{c}\text { Mean Difference } \\
\text { Fixed, } 95 \% \mathrm{Cl}\end{array}$} & \multirow[t]{2}{*}{ Weight } & \multirow{2}{*}{$\begin{array}{c}\text { Mean Difference } \\
\text { Fixed, } 95 \% \mathrm{Cl}\end{array}$} \\
\hline & $\mathbf{N}$ & Mean(SD) & $\mathbf{N}$ & Mean(SD) & & & \\
\hline \multicolumn{8}{|l|}{ 4.5.1 Final overjet } \\
\hline Eissa 2017 & 14 & $2.1(1.2)$ & 15 & $2.4(0.7)$ & & $100 \%$ & $-0.36[-1.07,0.35]$ \\
\hline Subtotal $\star \star \star$ & 14 & & 15 & & & $100 \%$ & $-0.36[-1.07,0.35]$ \\
\hline \multicolumn{8}{|c|}{ Heterogeneity: Not applicable } \\
\hline \multicolumn{8}{|c|}{ Test for overall effect: $Z=1(P=0.32)$} \\
\hline \multicolumn{8}{|l|}{ 4.5.2 Final ANB } \\
\hline Eissa 2017 & 14 & $6.7(3.1)$ & 15 & $7.2(1.5)$ & - & $35.83 \%$ & $-0.52[-2.32,1.28]$ \\
\hline Elkordy 2016 & 16 & $7(2)$ & 15 & $6.4(1.8)$ & & $64.17 \%$ & $0.63[-0.71,1.97]$ \\
\hline Subtotal $\star \star \star$ & 30 & & 30 & & & $100 \%$ & $0.22[-0.86,1.3]$ \\
\hline \multicolumn{8}{|c|}{ Heterogeneity: $\mathrm{Tau}^{2}=0 ; \mathrm{Chi}^{2}=1.01, \mathrm{df}=1(\mathrm{P}=0.32) ; \mathrm{I}^{2}=0.63 \%$} \\
\hline \multicolumn{8}{|c|}{ Test for overall effect: $\mathrm{Z}=0.4(\mathrm{P}=0.69)$} \\
\hline
\end{tabular}


Analysis 4.6. Comparison 4 Late orthodontic treatment: different types of appliances used for late treatment, Outcome 6 Fixed functional (FORSUS FRD) versus fixed functional with mini-implants (FMI) - patient satisfaction with results.

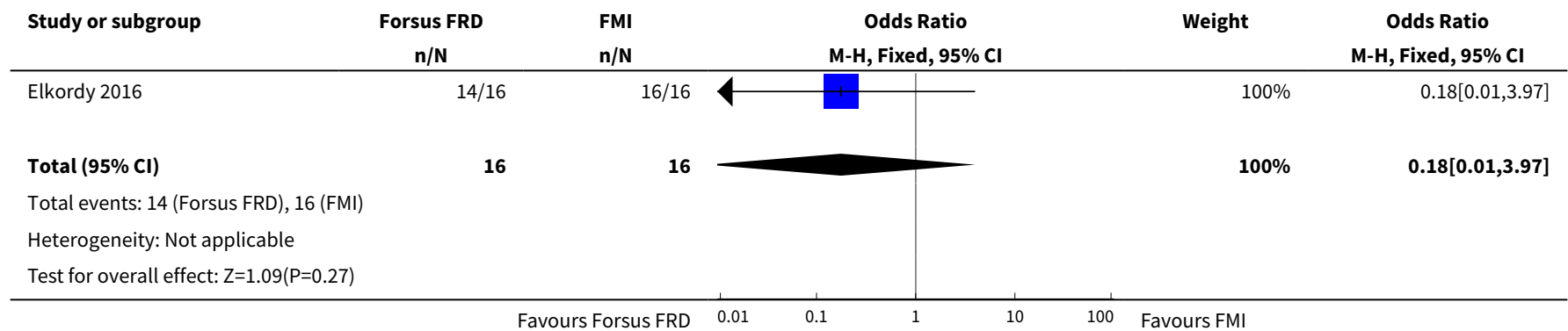

Analysis 4.7. Comparison 4 Late orthodontic treatment: different types of appliances used for late treatment, Outcome 7 R-appliance versus AIBP.

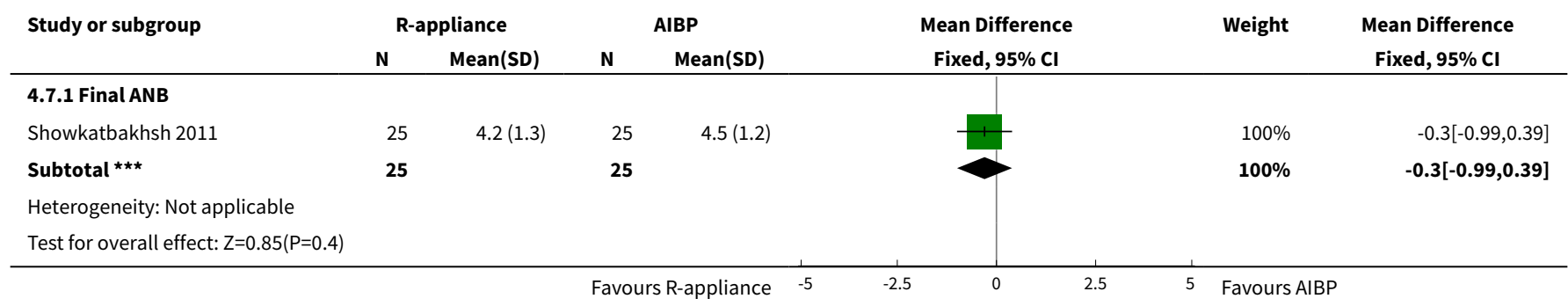

Analysis 4.8. Comparison 4 Late orthodontic treatment: different types of appliances used for late treatment, Outcome 8 Removable functional appliance versus fixed functional appliance.

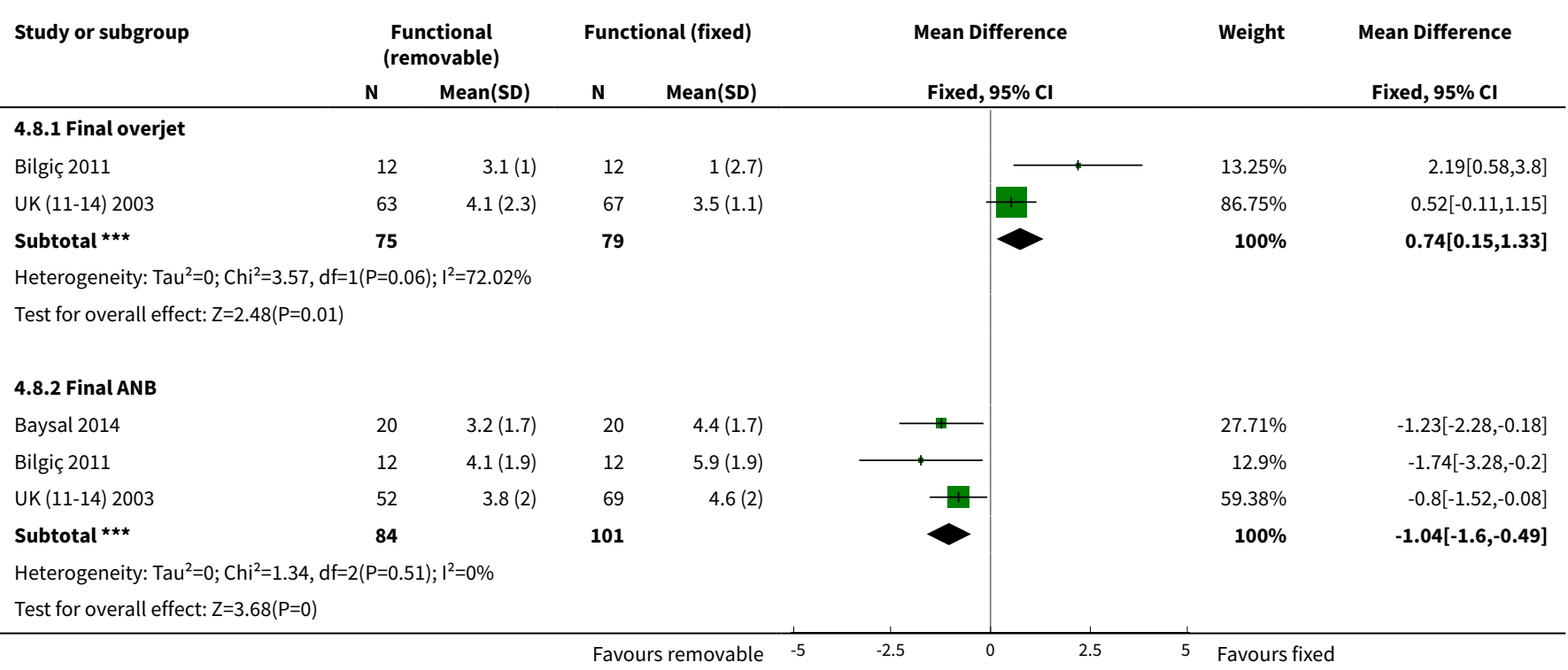


Analysis 4.9. Comparison 4 Late orthodontic treatment: different types of appliances used for late treatment, Outcome 9 FORSUS versus intermaxillary elastics.

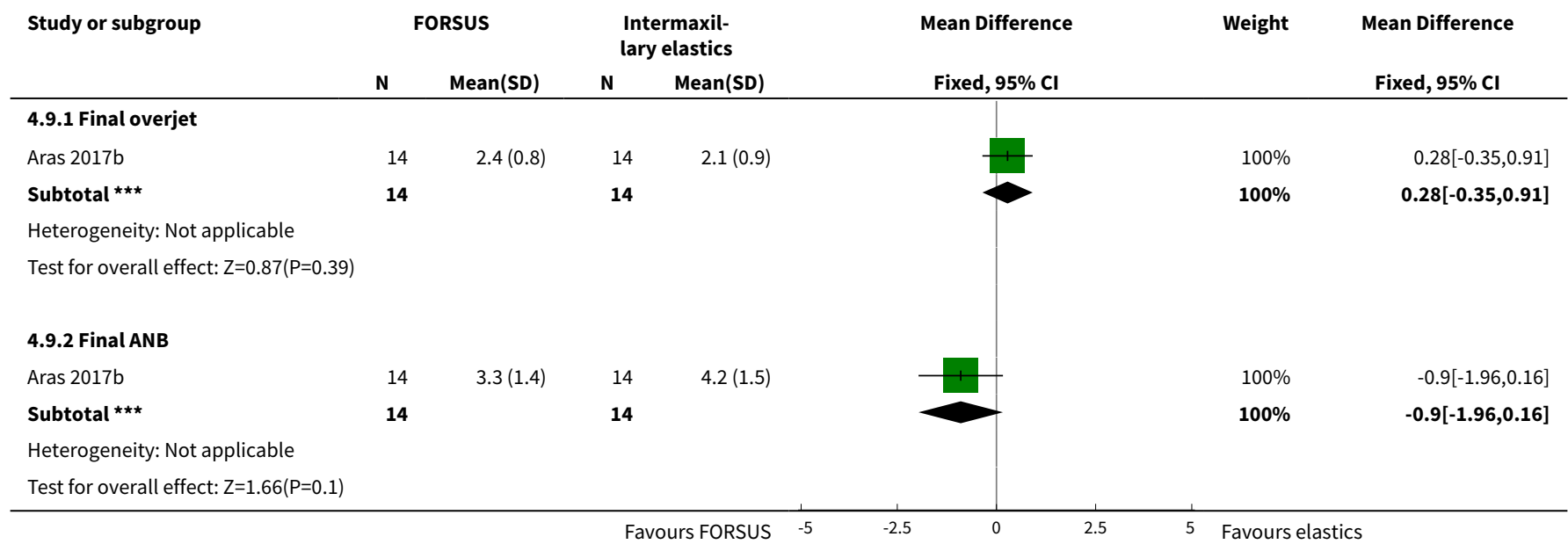

Analysis 4.10. Comparison 4 Late orthodontic treatment: different types of appliances used for late treatment, Outcome 10 FMA stepwise (SWG) versus FMA single step (SSG).

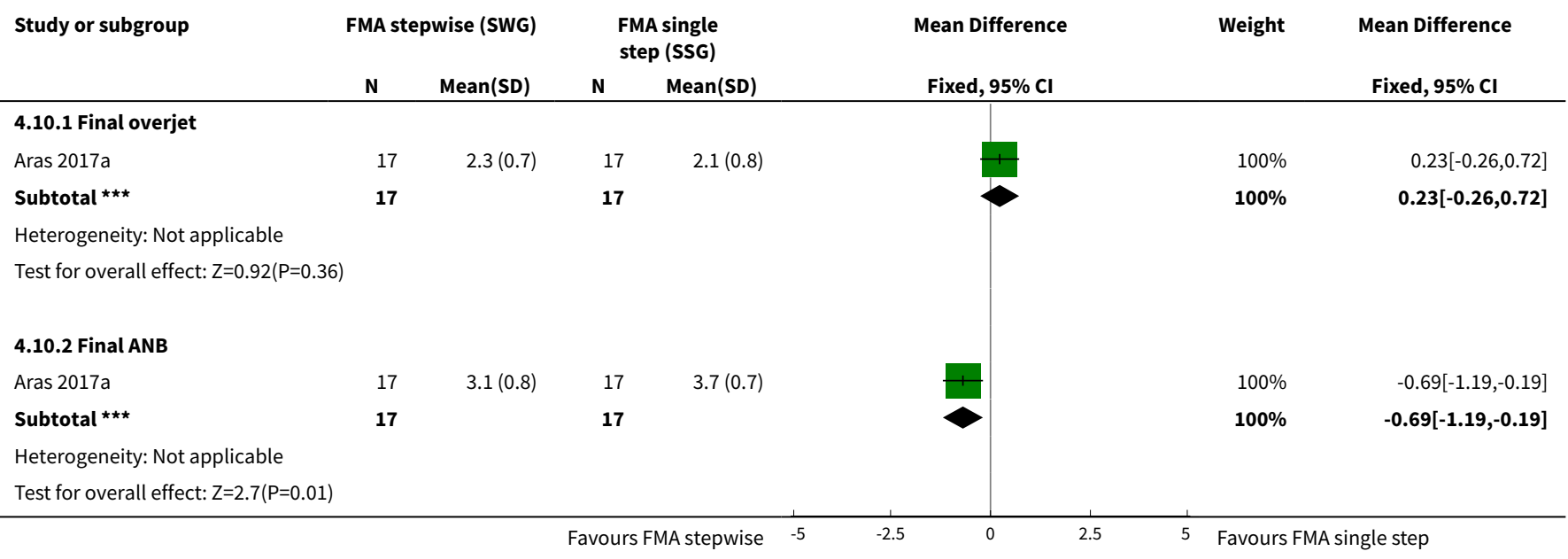

Analysis 4.11. Comparison 4 Late orthodontic treatment: different types of appliances used for late treatment, Outcome 11 Harvold Activator versus Frankel function regulator.

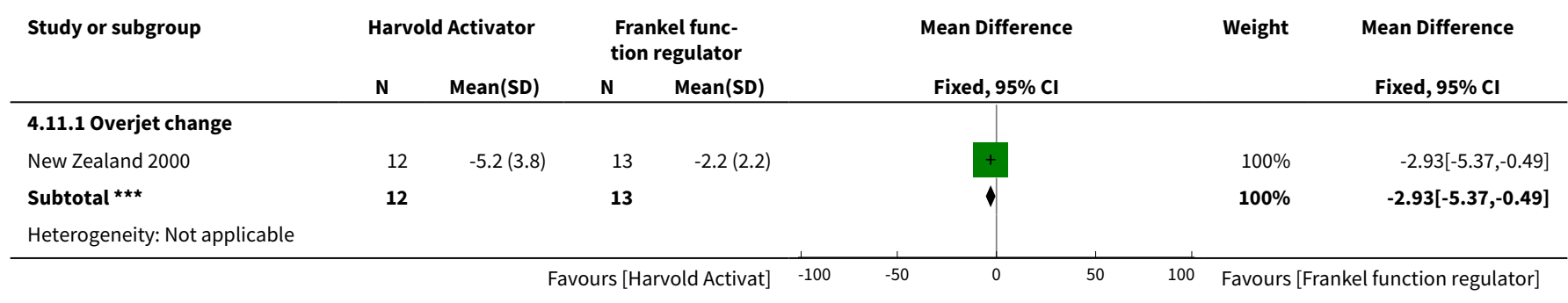




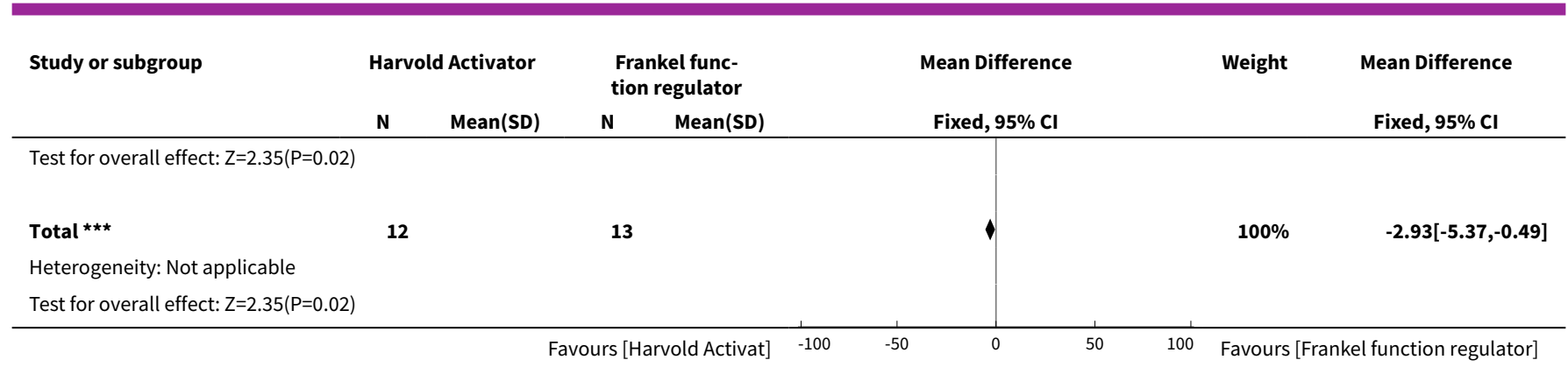

\section{APPENDICES}

\section{Appendix 1. Cochrane Oral Health's Trials Register search strategy}

From April 2013, searches of Cochrane Oral Health's Trials Register were conducted using the Cochrane Register of Studies and the search strategy below:

\#1 (orthodontic*:ti,ab) AND (INREGISTER)

\#2 ((appliance* or device*):ti,ab) AND (INREGISTER)

\#3 ((function* or remov* or fix* or intraoral or "intra oral" or intra-oral or extraoral or "extra oral" or extra-oral):ti,ab) AND (INREGISTER)

\#4 ((brace ${ }^{\star}$ or band or wire $^{\star}$ or headgear ${ }^{\star}$ or "head gear" or head-gear $\left.^{\star}\right):$ ti,ab) AND (INREGISTER)

\#5 (\#2 and \#3) AND (INREGISTER)

\#6 (("activator appliance*" or Frankel or "twin* block*" or FR-Il or "growth modif*" or "Two phase"):ti,ab) AND (INREGISTER)

\#7 ((orthopedic and dental):ti,ab) AND (INREGISTER)

\#8 ((orthopaedic and dental):ti,ab) AND (INREGISTER)

\#9 (\#1 or \#4 or \#5 or \#6 or \#7 or \#8) AND (INREGISTER)

\#10 ((retrognathi* or "posterior occlusion*"):ti,ab) AND (INREGISTER)

\#11 (("class II" and malocclusion*):ti,ab) AND (INREGISTER)

\#12 ((distocclusion* or disto-occlusion* or distoclusion* or "prominent upper front teeth" or overjet* or over-jet* or "over jet*"):ti,ab) AND

(INREGISTER)

\#13 (("Class 2" and malocclusion*):ti,ab) AND (INREGISTER)

$\# 14$ (\#10 or \#11 or \#12 or \#13) AND (INREGISTER)

$\# 15$ (\#9 and \#14) AND (INREGISTER)

Previous searches of Cochrane Oral Health's Trials Register were conducted using the Procite software and the search strategy below:

(orthodontic* or (appliance* and (function* or remov* or fix* or intraoral or "intra oral" or intra-oral or extraoral or "extra oral" or extraoral)) or brace* or band* or wire* or headgear* or "head gear" "intra oral" or intra-oral or extraoral or "extra oral" or extra-oral)) or "activator appliance*" or Frankel or "twin* block*" or FR-II or "growth modif*" or "Two phase" or (orthopedic and dental) or (orthopaedic and dental)) AND (retrognathi* or "posterior occlusion ${ }^{\star}$ or ("class II" and malocclusion*) or ("Class 2" and malocclusion*) or distocclusion* or disto-occlusion* or distoclusion* or "prominent upper front teeth" or overjet ${ }^{\star}$ or over-jet* or "over jet" ${ }^{\star \prime \prime}$

\section{Appendix 2. Cochrane Central Register of Controlled Trials (CENTRAL) search strategy}

\#1 MeSH descriptor Orthodontics explode all trees

\#2 ((appliance* in All Text near/5 function* in All Text) or (appliance* in All Text near/5 remov* in All Text) or (appliance* in All Text near/5 fix $^{\star}$ in All Text) or (appliance* in All Text near/5 intraoral in All Text) or (appliance* in All Text near/5 "intra oral" in All Text) or (appliance* in All Text near/5 intra-oral in All Text) or (appliance* in All Text near/5 extraoral in All Text) or (appliance* in All Text near/5 "extra oral" in All Text) or (appliance* in All Text near/5 extra-oral in All Text))

\#3 ((device* in All Text near/5 function* in All Text) or (device* in All Text near $/ 5$ remov* in All Text) or (device* in All Text near/5 fix* in All Text) or (device* in All Text near/5 intraoral in All Text) or (device* in All Text near/5 "intra oral" in All Text) or (device* in All Text near/5 intraoral in All Text) or (device* in All Text near/5 extraoral in All Text) or (device* in All Text near/5 "extra oral" in All Text) or (device* in All Text near/5 extra-oral in All Text))

\#4 (orthodontic* in All Text and (brace* in All Text or band* in All Text or wire* in All Text))

\#5 (orthodontic* in All Text and (extract* in All Text or remov ${ }^{\star}$ in All Text))

\#6 (orthodontic* in All Text and (headgear* in All Text or "head gear*" in All Text or head-gear in All Text))

\#7 "activator appliance*" in All Text

\#8 (Frankel in All Text or "twin* block*" in All Text or FR-Il in All Text)

Orthodontic treatment for prominent upper front teeth (Class II malocclusion) in children and adolescents (Review) 
\#9 ( (growth in All Text near/3 modif* in All Text) and (jaw* in All Text or maxilla* in All Text or mandib* in All Text) )

\#10 (two-phase in All Text and (treatment in All Text or therapy in All Text) and (orthodontic* in All Text or malocclusion* in All Text) )

$\# 11$ ( (orthopedic* in All Text or orthopaedic* in All Text) and (dental in All Text or orthodontic* in All Text or facial in All Text) )

$\# 12$ (\#1 or \#2 or \#3 or \#4 or \#5 or \#6 or \#7 or \#8 or \#9 or \#10 or \#11)

$\# 13 \mathrm{MeSH}$ descriptor Malocclusion, Angle Class II this term only

\#14 MeSH descriptor Retrognathism this term only

\#15 ( ("class II" in All Text near/3 malocclusion* in All Text) or ("class 2" in All Text near/3 malocclusion* in All Text) ) \#16 (posterior in All

Text near/3 occlusion* in All Text)

\#17 (distoclusion* in All Text or disto-occlusion* in All Text or distocclusion* in All Text)

\#18 retrognath* in All Text

\#19 "prominent upper front teeth" in All Text

\#20 (overjet ${ }^{\star}$ in All Text or "over jet*" in All Text or over-jet* in All Text)

$\# 21$ (\#13 or \#14 or \#15 or \#16 or \#17 or \#18 or \#19 or \#20)

\#22 (\#12 and \#21)

\section{Appendix 3. MEDLINE Ovid search strategy}

1. exp Orthodontics/

2. (appliance $\operatorname{adj} 5$ (function\$ or remova\$ or fix\$)).mp.

3. (orthodontic\$ and (brace\$ or band\$ or wire\$)).mp.

4. (orthodontic\$ and (extract\$ or remov\$)).mp.

5. (orthodontic\$ and (headgear\$ or "head gear\$" or head-gear\$)).mp.

6. (device adj5 (function\$ or remova or fix\$)).mp.

7. ((appliance\$ or device\$) adj5 (intraoral or "intra oral" or intra-oral or extraoral or "extra oral" or extra-oral)).mp.

8. (activator adj appliance\$).mp.

9. (Frankel or "twin\$ block\$" or FR-II).mp.

10. ((growth adj3 modif\$) and (jaw\$ or maxilla\$ or mandible\$ or mandibular)).mp.

11. (two-phase and (treatment or therapy) and (orthodontic\$ or malocclusion\$)).mp.

12. ((orthopedic\$ or orthopaedic\$) and (dental or orthodontic\$ or facial)).mp.

13. or/1-12

14. Malocclusion, Angle Class II/

15. Retrognathism/

16. (("class II" or "class 2") adj3 malocclusion\$).mp.

17. (posterior adj3 occlusion\$).mp.

18. (distoclusion\$ or disto-occlusion\$ or distocclusion\$).mp.

19. retrognath $\$ . m p$.

20. (prominent adj3 upper adj3 teeth).mp.

21. (overjet\$ or "over jet\$" or over-jet\$).mp.

22. or/14-21

23. 13 and 22

The above subject search was linked to the Cochrane Highly Sensitive Search Strategy (CHSSS) for identifying randomised trials in MEDLINE: sensitivity maximising version (2008 revision) as referenced in Chapter 6.4.11.1 and detailed in box 6.4.c of theCochrane Handbook for Systematic Reviews of Interventions, Version 5.1.0 [updated March 2011] (Lefebvre 2011).

1. randomized controlled trial.pt.

2. controlled clinical trial.pt.

3. randomized.ab.

4. placebo.ab.

5. drug therapy.fs.

6. randomly.ab.

7. trial.ab.

8. groups.ab.

9. or/1-8

10. exp animals/ not humans.sh.

11.9 not 10

\section{Appendix 4. Embase Ovid search strategy}

1. exp Orthodontics/

2. (appliance $\mathbf{a d j 5}$ (function\$ or remova\$ or fix\$)).mp.

3. (orthodontic\$ and (brace\$ or band\$ or wire\$)).mp.

4. (orthodontic\$ and (extract\$ or remov\$)).mp. 
5. (orthodontic\$ and (headgear\$ or "head gear\$" or head-gear\$)).mp.

6. (device\$ adj5 (function\$ or remova $\$$ or fix\$)).mp.

7. ((appliance\$ or device\$) adj5 (intraoral or "intra oral" or intra-oral or extraoral or "extra oral" or extra-oral)).mp.

8. (activator adj appliance\$).mp.

9. (Frankel or "twin\$ block\$" or FR-II).mp.

10. ((growth adj3 modif\$) and (jaw\$ or maxilla\$ or mandible\$ or mandibular)).mp.

11. (two-phase and (treatment or therapy) and (orthodontic\$ or malocclusion\$)).mp.

12. ((orthopedic $\$$ or orthopaedic\$) and (dental or orthodontic\$ or facial)).mp.

13. or/1-12

14. Retrognathia/

15. (("class II" or "class 2") adj3 malocclusion\$).mp.

16. (posterior adj3 occlusion\$).mp.

17. (distoclusion\$ or disto-occlusion\$ or distocclusion\$).mp.

18. retrognath\$.mp.

19. (prominent adj3 upper adj3 teeth).mp.

20. (overjet\$ or "over jet\$" or over-jet\$).mp.

21. or/14-20

22. 13 and 21

The above subject search was linked to adapted version of the Cochrane Embase Project filter for identifying RCTs in Embase Ovid (see http://www.cochranelibrary.com/help/central-creation-details.html for information):

1. Randomized controlled trial/

2. Controlled clinical study/

3. Random\$.ti,ab.

4. randomization/

5. intermethod comparison/

6. placebo.ti,ab.

7. (compare or compared or comparison).ti.

8. ((evaluated or evaluate or evaluating or assessed or assess) and (compare or compared or comparing or comparison)).ab.

9. (open adj label).ti,ab.

10. ((double or single or doubly or singly) adj (blind or blinded or blindly)).ti,ab.

11. double blind procedure/

12. parallel group $\$ 1 . t i, a b$.

13. (crossover or cross over).ti,ab.

14. ((assign\$ or match or matched or allocation) adj5 (alternate or group\$1 or intervention\$1 or patient $\$ 1$ or subject $\$ 1$ or participant

\$1)).ti,ab.

15. (assigned or allocated).ti,ab.

16. (controlled adj7 (study or design or trial)).ti,ab.

17. (volunteer or volunteers).ti,ab.

18. trial.ti.

19. or/1-18

20. (exp animal/ or animal.hw. or nonhuman/) not (exp human/ or human cell/ or (human or humans).ti.)

21. 19 not 20

Appendix 5. US National Institutes of Health Ongoing Trials Register (ClinicalTrials.gov) search strategy

"class II malocclusion"

retrognath*

overjet or "posterior occlusion"

"prominent upper front teeth"

\section{Appendix 6. World Health Organization International Clinical Trials Registry Platform search strategy}

"class II malocclusion" or "class 2 malocclusion"

retrognath*

overjet or "posterior occlusion"

"prominent upper front teeth"

\section{WHAT'S NEW}




\begin{tabular}{lll}
\hline Date & Event & Description \\
\hline 30 November 2017 & $\begin{array}{l}\text { New citation required and conclusions } \\
\text { have changed }\end{array}$ & $\begin{array}{l}\text { The quality of the evidence to support treating prominent up- } \\
\text { per front teeth in one phase in adolescence (late treatment with } \\
\text { functional appliance versus no treatment) is now 'low'. It was } \\
\text { previously 'very low'. }\end{array}$ \\
\hline 27 September 2017 & New search has been performed & Search updated until 27 September 2017 \\
& 11 new studies included \\
\hline
\end{tabular}

\section{HISTORY}

Protocol first published: Issue 1, 2002

Review first published: Issue 3, 2007

\begin{tabular}{lll}
\hline Date & Event & Description \\
\hline 4 March 2014 & Amended & Minor edit to forest plots. \\
\hline 14 November 2013 & Amended & Minor edit. \\
\hline 7 November 2013 & $\begin{array}{l}\text { New citation required and conclusions } \\
\text { have changed }\end{array}$ & $\begin{array}{l}\text { New methods including risk of bias implemented. Inclusion cri- } \\
\text { teria modified to exclude controlled clinical trials and quasi-ran- } \\
\text { domised trials. 9 new included trials, conclusions changed. Sum- } \\
\text { mary of findings tables added. }\end{array}$ \\
\hline 7 November 2013 & New search has been performed & Searches updated to April 2013. \\
\hline 23 June 2008 & Amended & Converted to new review format. \\
\hline
\end{tabular}

\section{CONTRIBUTIONS OFAUTHORS}

The original review (2007) was conceived by Jayne E Harrison (JH), Kevin D O'Brien (KOB) and Bill Shaw (Cochrane Oral Health). Sylvia Bickley (Cochrane Oral Health) developed the search strategy and undertook the electronic searches. JH and KOB screened the search results, retrieved papers and undertook the risk of bias assessment of the papers and data extraction. KOB and Helen $\mathrm{V}$ Worthington (HW) undertook the data analysis. KOB, HW and JH wrote the original review.

The first update (2013) was co-ordinated by Badri Thiruvenkatachari (BT) and KOB. Anne Littlewood (Cochrane Oral Health) developed the search strategy and undertook the electronic searches. All review authors screened the search results and retrieved papers, undertook the risk of bias assessment of the papers and extracted data from them. BT and KOB analysed the data and interpreted the results. BT and KOB wrote the results, conclusions and discussion sections of the review.

The current update (2017) was co-ordinated by Klaus BSL Batista (KB), BT and KOB. Anne Littlewood (Cochrane Oral Health) developed the search strategy and undertook the electronic searches. KB, BT and JH screened the search results and retrieved papers, undertook the risk of bias assessment of the papers and extracted data from them. KB, BT and KOB wrote the results, conclusions and discussion sections of the review.

\section{DECLARATIONS OF INTEREST}

Klaus BSL Batista: no interest to declare.

Kevin O'Brien was involved in acquiring funding, running and reporting of the UK (11-14) 2003, UK (Mixed) 2009 and Banks 2004 trials; however, he was not involved in the quality assessment of these trials.

Badri Thiruvenkatachari and Helen Worthington (author on previous versions) are among the authors of UK (Mixed) 2009; however, they were not involved in the risk of bias assessment of this trial. Helen V Worthington is a Co-ordinating Editor with Cochrane Oral Health. 
Badri Thiruvenkatachari and Kevin O'Brien were involved in running and reporting the Thiruvenkatachari 2010 (Dynamax) study; however, they were not involved in the quality assessment of this trial.

Jayne E Harrison: no interest to declare. Dr Harrison is an Editor with Cochrane Oral Health.

\section{SOURCES OF SUPPORT}

\section{Internal sources}

- The Royal Liverpool and Broadgreen University Hospitals NHS Trust, UK.

- School of Dentistry, The University of Manchester, UK.

- Manchester Academic Health Sciences Centre (MAHSC) and NIHR Manchester Biomedical Research Centre, UK.

\section{External sources}

- NHS National Primary Dental Care R\&D programme PCD97-303, UK.

- Cochrane Oral Health Global Alliance, Other.

The production of Cochrane Oral Health reviews has been supported financially by our Global Alliance since 2011 (oralhealth.cochrane.org/partnerships-alliances). Contributors over the past year have been the American Association of Public Health Dentistry, USA; the British Association for the Study of Community Dentistry, UK; the British Society of Paediatric Dentistry, UK; the Canadian Dental Hygienists Association, Canada; the Centre for Dental Education and Research at All India Institute of Medical Sciences, India; the National Center for Dental Hygiene Research \& Practice, USA; New York University College of Dentistry, USA; NHS Education for Scotland, UK; and the Swiss Society for Endodontology, Switzerland.

- National Institute for Health Research (NIHR), UK.

This project was supported by the NIHR, via Cochrane Infrastructure funding to Cochrane Oral Health. The views and opinions expressed herein are those of the review authors and do not necessarily reflect those of the Systematic Reviews Programme, the NIHR, the NHS or the Department of Health.

\section{DIFFERENCES BETWEEN PROTOCOLANDREVIEW}

In the last update of this review, we decided to include only truly randomised controlled trials. Quasi-randomised trials and controlled clinical trials were excluded.

In this update, we made minor modifications to the objectives and outcomes for clarity. We added 'and adolescents' to the title. We clarified that early treatment was two-phase and that the age range for late treatment was 'around' 12 to 16 years. We moved New Zealand study in late treatment category as the authors felt the participants were treated in one phase.

\section{INDEX TERMS}

\section{Medical Subject Headings (MeSH)}

*Orthodontic Appliances, Functional [adverse effects]; *Orthodontic Retainers [adverse effects]; Age Factors; Extraoral Traction Appliances; Malocclusion, Angle Class II [^therapy]; Orthodontics, Corrective [adverse effects] [^methods]; Randomized Controlled Trials as Topic; Treatment Outcome

\section{MeSH check words}

Adolescent; Child; Humans 